JAMILE CALIL SILVEIRA

\title{
EFEITO DA ADMINISTRAÇÃO AGUDA DE IODO NA EXPRESSÃO GÊNICA E ATIVIDADE DO PROMOTOR DA PENDRINA: ESTUDOS EM RATOS E EM CÉLULAS PCCI3
}

\begin{abstract}
Tese apresentada ao Programa de PósGraduação em Fisiologia do Instituto de Ciências Biomédicas da Universidade de São Paulo, para obtenção do Titulo de Doutor em Ciências para obtenção do título de doutor em Ciências.
\end{abstract}

São Paulo

2014 


\section{JAMILE CALIL SILVEIRA}

\section{EFEITO DA ADMINISTRAÇÃO AGUDA DE IODO NA EXPRESSÃO GÊNICA E ATIVIDADE DO PROMOTOR DA PENDRINA: ESTUDOS EM RATOS E EM CÉLULAS PCCI3}

Tese apresentada ao Programa de PósGraduação em Fisiologia do Instituto de Ciências Biomédicas da Universidade de São Paulo para obtenção do Título de Doutor em Ciências

Área de Concentração: Fisiologia humana.

Orientadora: Prof $\stackrel{a}{\text { a }}$ Dra. Maria Tereza Nunes

Versão original

São Paulo

2014 
DADOS DE CATALOGAÇÃO NA PUBLICAÇÃO (CIP)

Serviço de Biblioteca e Informação Biomédica do

Instituto de Ciências Biomédicas da Universidade de São Paulo

reprodução não autorizada pelo autor

Silveira, Jamile Calil.

Efeito da administração aguda de iodo na expressão gênica e atividade do promotor da pendrina: estudos em ratos e em células PCCL3 / Jamile Calil Silveira. -- São Paulo, 2014.

Orientador: Profa. Dra. Maria Tereza Nunes.

Tese (Doutorado) - Universidade de São Paulo. Instituto de Ciências Biomédicas. Departamento de Fisiologia e Biofísica. Área de concentração: Fisiologia Humana. Linha de pesquisa: Regulação hormonal da expressão gênica.

Versão do título para o inglês: Effect of acute administration of iodine on pendrin gene expression and the activity of pendrin promoter: studies in rats and PCCL3 cells.

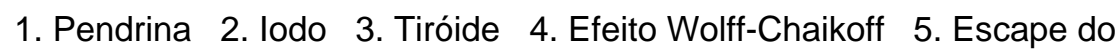
efeito Wolff-Chaikoff 6. Autorregulação da Tiróide I. Nunes, Profa.

Dra. Maria Tereza II. Universidade de São Paulo. Instituto de Ciências Biomédicas. Programa de Pós-Graduação em Fisiologia Humana III. Título. 


\section{UNIVERSIDADE DE SÃO PAULO \\ INSTITUTO DE CIÊNCIAS BIOMÉDICAS}

Candidato(a): $\quad$ Jamile Calil Silveira.

Título da Tese: $\quad$ Efeito da administração aguda de iodo na expressão gênica e atividade do promotor da pendrina: estudos em ratos e em células PCCL3.

Orientador(a):

Profa. Dra. Maria Tereza Nunes.

A Comissão Julgadora dos trabalhos de Defesa da Tese de Doutorado, em sessão pública realizada a considerou
( ) Aprovado(a)
( ) Reprovado(a)

\begin{tabular}{|c|c|}
\hline Examinador(a): & $\begin{array}{l}\text { Assinatura: } \\
\text { Nome: ......... } \\
\text { Instituição: . }\end{array}$ \\
\hline Examinador(a): & $\begin{array}{l}\text { Assinatura: } \\
\text { Nome: ......... } \\
\text { Instituição: . }\end{array}$ \\
\hline Examinador(a): & $\begin{array}{l}\text { Assinatura: } \\
\text { Nome: ......... } \\
\text { Instituição: . }\end{array}$ \\
\hline Examinador(a): & $\begin{array}{l}\text { Assinatura: } \\
\text { Nome: ......... } \\
\text { Instituição: . }\end{array}$ \\
\hline Presidente: & $\begin{array}{l}\text { Assinatura: } \\
\text { Nome: ......... } \\
\text { Instituição: . }\end{array}$ \\
\hline
\end{tabular}




\title{
CERTIFICADO DA COMISSÃO DE ÉTICA
}

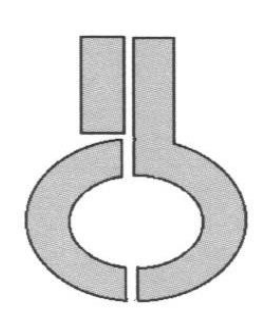

\author{
UNIVERSIDADE DE SÃO PAULO \\ INSTITUTO DE CIÊNCIAS BIOMÉDICAS
}

Cidade Universitária "Armando de Salles Oliveira"

Av. Prof. Lineu Prestes, 2415 - CEP. 05508-000 São Paulo, SP Brasil

Telefone :(55) (011) 3091.7733 - e-mail: cep@icb.usp.br

\section{Certificado}

Certificamos que o protocolo registrado sob $n^{\circ} \mathbf{1 5 6}$ nas fls. 137 do livro 02 para uso de animais em experimentação, sob a responsabilidade do Prof(a) Dr(a)) Maria Tereza Nunes, Coordenador (a) da Linha de pesquisa "Efeito do tratamento agudo de iodo sobre a regulação transcricional e pós-transcricional da expressão de genes em tecidos que expressam o co-transportador de sódio-iodeto (NIS)" do qual participam o(s) aluno(s),Caroline Serrano do Nascimento, Jamile Calil Silveira está de acordo com os Princípios Éticos de Experimentação Animal adotado pela Sociedade Brasileira de Ciência de Animais de Laboratório (SBCAL) e foi aprovado pela COMISSÃO DE ÉTICA NO USO DE ANIMAIS (CEUA) em 30.10.2012, com validade de 4 anos.

São Paulo, 31 de outubro de 2012.

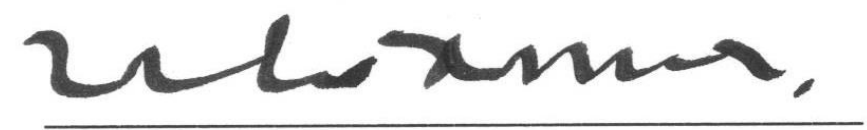

Prof. Dr. WOTHAN TAVARES DE LIMA Coordenador-CEUA - ICB/USP

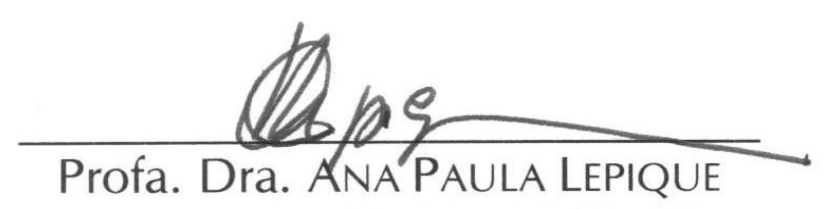

Secretária- CEUA - ICB/USP 


\section{AGRADECIMENTOS}

A FAPESP, cujo suporte financeiro tornou esse doutorado possível.

A Professora Maria Tereza, pela orientação, apoio e paciência (muita) que me dedica desde a Iniciação Científica.

A Lhô, que começa ajudando com o suporte técnico, mas que acaba se tornando uma grande amiga, dando suporte psicológico.

Aos colegas de laboratório, Carol, Ana Cá, Mari, Paula, Prévide, Rafa Croffi, Sil, Rafa Salgueiro e Rodrigo. Obrigada por toda a ajuda e bom convívio no dia a dia. Tenho sorte em ter vocês como colegas de lab.

Aos amigos Rafa Croffi, Carol, Sil, Ana Ca, Mari, Prévide, Rafa Salgueiro. Não existem palavras para descrever o que vocês fazem por mim no dia a dia. Amo vocês!

Ao Dr Peter Kopp, Noemi Kopp e Daphnee. A sorte que eu tive em conhecê-los é imensurável.

A Aigerim e Leila, que se tornaram parte da minha família.

A Emmanuelle e Bruno, que me mostraram que na vida a gente nunca está sozinho.

A turma da Northwestern University: Vickie Howard, Diana, Sherry, Donita, Elizabeth, Elona, Xao-win, Ana. Obrigada por todo o suporte durante meu estágio.

Finalmente, agradeço a minha família pelo meu passado, presente e desde já, pelo futuro! 


\section{EPÍGRAFE}

"Procure ser uma pessoa de valor, em vez de procurar ser uma pessoa de sucesso. $O$ sucesso é conseqüência"

Albert Einstein

O desafio de um bom pesquisador é não somente construir conhecimento, mas ser humano durante a sua trajetória. 


\section{RESUMO}

CALIL-SILVEIRA, J. Efeito da administração aguda de iodo na expressão gênica e atividade do promotor da pendrina: estudos em ratos e em células PCCL3. 2014. $91 \mathrm{f}$. Tese (Doutorado em Fisiologia) - Ins国tuto de Ciências Biomédicas, Universidade de São Paulo, São Paulo, 2014.

Pendrina é uma proteína transportadora de ânions, codificada pelo gene PDS. Ela é expressa em vários tecidos, bem como na tiróide, onde está inserida na membrana apical de células foliculares. Estudos demonstraram que a pendrina pode mediar o efluxo apical do iodeto dos tirócitos para o lúmen folicular. Sabendo-se que o iodo é fundamental para a síntese de hormônios tiroidianos e considerando-se que a expressão de alguns mRNAs que codificam proteínas envolvidas com o transporte de oligominerais é modificada por alterações no aporte dos mesmos, foi objetivo deste trabalho avaliar, por meio de estudos in vivo e in vitro, o efeito da administração aguda de iodo na expressão do mRNA e proteína pendrina em curtos períodos de tempo (30 min à $48 \mathrm{~h}$ ), bem como analisar o efeito desse tratamento na atividade da região promotora do gene PDS. Buscamos ainda avaliar se o tratamento com iodeto seria capaz de alterar a taxa de elfuxo de células tiroidianas. Foram utilizados ratos Wistar, divididos nos grupos: controle e iodo, os quais receberam injeção ip de salina ou $2 \mathrm{mg} / \mathrm{animal}$ de $\mathrm{Nal}$, respectivamente. Foram decapitados após 30 ', 1, 24 e $48 \mathrm{~h}$ da administração do iodo/salina. As tiroides foram removidas para análise da expressão do mRNA e proteína pendrina, através de PCR em Tempo Real e western blotting, respectivamente. Para o estudo in vitro foi utilizada a linhagem celular de tiroide de rato $\mathrm{PCCl} 3$, que ao atingir $70 \%$ de confluência, foi tratada ou não com $10^{-3} \mathrm{M}$ de Nal. As células permaneceram sob tratamento por 30', 1, 24 e $48 \mathrm{~h}$, quando então foram removidas e o RNA/proteína extraídos também para a análise da expressão do mRNA e proteína pendrina. A localização de proteínas no tirócito foi determinada por Imunofluorescência, e a taxa de efluxo foi determinada pela medição do ${ }^{125}$ I presente no meio de cultura. Para analisar a atividade do promotor de PDS, este foi inserido no vetor pGL3básico, que contém o gene da luciferase, cuja atividade serviu como indicador da atividade deste promotor nas condições de tratamento estudadas. Nossos resultados mostram que houve aumento significativo do mRNA da pendrina em resposta ao iodo em todos os tempos estudados, in vivo e in vitro. Esse efeito foi prevenido quando o perclorato, conhecido inibidor de NIS, foi administrado junto ao iodo, o que indica que ele depende da presença do iodeto intracelular, bem como quando as células foram tratadas com actinomicina $D$, indicando que o aumento deste mRNA decorreu de estímulo transcricional. Tal estímulo parece ocorrer via Fator Transcricional 1. A expressão da proteína pendrina aumentou apenas nos tempos mais longos de tratamento (24 e 48 h). Também nos tempos mais longos, houve aumento da localização da pendrina na membrana plasmática, bem como aumento na taxa de efluxo de iodeto das células $\mathrm{PCCl}$. Esse dado seria coerente com um importante papel de pendrina transportando o iodeto apical dos tirócitos, e contribuindo para o fenômeno de Escape do efeito Wolff-Chaikoff, que ocorre somente a partir de $24 \mathrm{~h}$ da exposição ao excesso de iodo.

Palavras-Chave: Pendrina. lodo. Expressão gênica. Tiróide. Efeito Wolff-Chaikoff. Escape 


\begin{abstract}
CALIL-SILVEIRA, J. Effect of acute administration of iodine on pendrin gene expression and the activity of pendrin promoter: studies in rats and $\mathrm{PCCl} 3$ cells. 2014. 91 f. [Ph. D. Thesis (Human Physiology)]. São Paulo, Instituto de Ciências Biomédicas, Universidade de São Paulo, 2014.
\end{abstract}

Pendrin, an anion exchange, is codified by PDS gene and it is expressed in different tissues. In thyroid, it is located at the apical membrane of thyrocytes. Studies have suggested that pendrin could function as an apical iodide transporter in thyroid cells. Since iodine is essential for thyroid hormone synthesis and this element is known to regulate the expression of different genes in thyroid that are related to its transport, this study attempted to investigate that possibility by evaluating whether the acute iodide administration, from 30 min up to $48 \mathrm{~h}$, could regulate the pendrin mRNA and protein expression, as well as the localization and activity of this protein. Moreover, this study aimed to analyze if the treatment with iodide could regulates the pendrin promoter. Rats received $\mathrm{Nal}(2 \mathrm{mg} / 0.5 \mathrm{ml}$ saline) or saline ip $(0,9 \% \mathrm{NaCl})$, and were sacrificed $30 \mathrm{~min}$, 1,24 and $48 \mathrm{~h}$ later. The thyroid was removed, and the total RNA and protein extracted. Pendrin mRNA content was evaluated by Real-Time PCR and the protein by Western blotting. For in vitro study, $\mathrm{PCCl} 3$ rat thyroid cells were cultured and, when the cells reached $70 \%$ confluence, they were treated or not with $10^{-3} \mathrm{M} \mathrm{Nal}$. After $30 \mathrm{~min}, 1 \mathrm{~h}, 24 \mathrm{~h}$ and $48 \mathrm{~h}$ of treatment, untreated cells and iodide-treated cells were harvested and total RNA and protein were extracted for analyze by Real-Time PCR and Western blotting. The protein localization was performed by immunofluorescence, and the pendrin activity was determined by the measured of ${ }^{125} \mathrm{I}$ in the culture medium. The promoter analyzes were made by the insertion of PDS promoter in the pGL3-basic plasmid, upstream the luciferase gene, which activity indicated the PDS promoter activity under iodide treatment. The results show that the pendrin mRNA expression significantly increased in all groups of study, in vivo and in vitro. The effect was prevented when the animals and cells were treated with perchlorate concomitantly with iodide, for $30 \mathrm{~min}$, indicating that the intracellular iodide is the one who triggers the effect. The effect was also prevented when cells were treated with actinomycin $\mathrm{D}$, a blocker of gene transcription, indicating that excess of iodide leads to an activation of pendrin gene transcription. Apparently, TTF-1 is the responsible for this activation. The protein expression was increased only after 24 and 48 hours of treatment. Moreover, only after 12 hours of treatment was observed more pendrin at the membrane, and a higher rate of iodide efflux in $\mathrm{PCCl} 3$ cells. This date suggests an important role of pendrin on iodide transport at the apical membrane, contributing to the Wolff-Chaikoff effect and Escape phenomenon, which occurs only after 24-48 hours of the blockage.

Keywords: Pendrin. lodine. Gene expression. Thyroid. Wolff-Chaikoff effect. Escape 


\section{LISTA DE ILUSTRAÇÕES}

Figura 1 - Representação das proteínas envolvildas no metabolismo e transporte de iodeto no

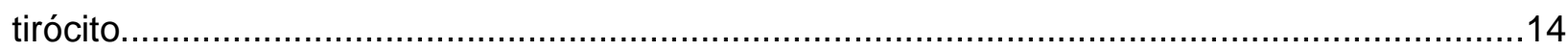

Figura 2 - Esquema do plasmídeo pGL3-basic...................................................................28

Figura 3 - Esquema do ensaio de Imunoprecipitação da Cromatina (ChIP assay) .....................30

Figura 4 - Representação gráfica do conteúdo do mRNA de Pendrina em tiróide de ratos........37

Figura 5 - Representação gráfica do conteúdo do mRNA de Pendrina em células PCCL3.......38

Figura 6 - Avaliação da expressão do mRNA de Pendrina em grupos tratados com Perclorato e

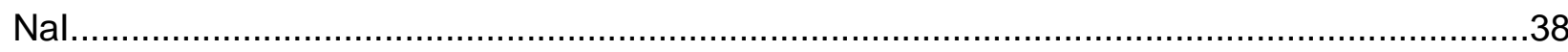

Figura 7 - Avaliação da meia-vida do transcrito de pendrina em células PCCI3........................39

Figura 8 - Efeito do bloqueio da transcrição gênica na expressão do mRNA de pendrina ........40

Figura 9 - Efeito da administração de Nal na expressão do CIC-5 em células PCCl3................41

Figura 10 - Avaliação da expressão do mRNA do fator transcricional tiroidiano TTF-1.............41

Figura 11 - Avaliação da localização do fator transcricional TTF-1 por imunofluorescência.......42

Figura 12 - Avaliação da localização subcelular do fator transcricional TTF-1...........................43

Figura 13 - Avaliação da atividade do promotor de PDS de rato..............................................43

Figura 14 - Avaliação da atividade do promotor de PDS humano.............................................4

Figura 15 - Efeito da deleção de parte do promotor de PDS humano........................................45

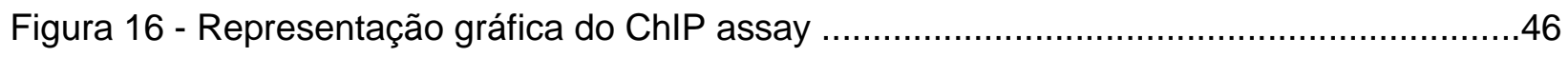

Figura 17 - Investigação da região $15 \mathrm{~kb}$ upstream ao promotor de PDS em células PCCI3....46

Figura 18 - Avaliação do conteúdo total da pendrina em ratos................................................47

Figura 19 - Avaliação do conteúdo total da pendrina em células PCCI3...................................48

Figura 20 - Avaliação do conteúdo total da pendrina em células PCCI3 (doses menores Nal)..49

Figura 21 - Localização subcelular da proteína Pendrina - Imunofluorescência. .......................51 
Figura 22 - Avaliação da taxa de efluxo de iodeto em células PCCl3 tradas com Nal - tempos curtos. .52

Figura 23 - Avaliação da taxa de efluxo de iodeto em células PCCl3 tradas com Nal - tempos longos. .53

Figura 24 - Avaliação da taxa de efluxo de iodeto no tempo de coleta T1 dos grupos tratados por longos períodos com $\mathrm{Nal}$.. .54

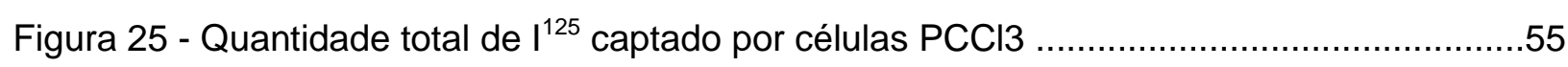

Figura 26 - Representação dos eventos desencadeados pelo de iodeto no tirócito.. 60 


\section{LISTA DE ABREVIATURAS E SIGLAS}

NIS - Co-transportador de Sódio e iodeto

PDS - gene que codifica a pendrina

TPO - Tireoperoxidase

$\mathrm{H}_{2} \mathrm{O}_{2}$ - Peróxido de Hidrogênio

DUOX - Sistema gerador de peróxido de hidrogênio

TG - Tireoglobulina

TSH - Hormônio Estimulante da tiróide

TSHR - Receptor do Hormônio Estimulante da tiróide

CIC-5 - Canal de Cloreto 5

hPDS - gene que codifica a pendrina humana

TTF-1 - Fator Transcricional da Tiróide -1

TTF-2 - Fator Transcricional da Tiróide -2

PAX-8 - Paired Box Gene 8

TGF $\beta$ - Fator de transformação do crescimento $\beta$ 


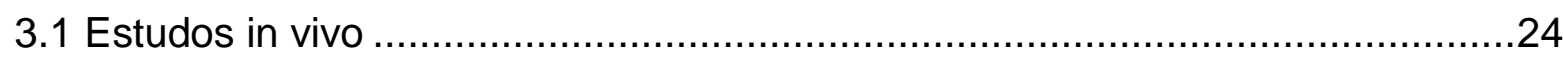

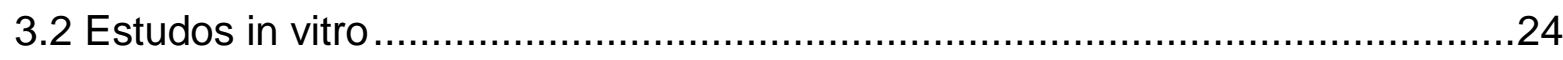

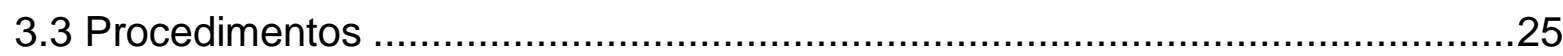

3.3.1 Avaliação da expressão do mRNA de pendrina frente ao excesso de iodeto.25

3.3.2 Avaliação da meia-vida do transcrito de pendrina ........................................26

3.3.3 Avaliação da expressão do mRNA do TTF-1 …..........................................26

3.3.4 Avaliação, por imunofluorescência, da localização do TTF-1 ........................27

3.3.5 Avaliação da localização subcelular do TTF-1 ..............................................27

3.3.6 Avaliação da atividade do promotor de PDS de rato ...................................28

3.3.7 Avaliação da atividade do promotor de PDS de humano (hPDS)...................29

3.3.8 Avaliação da ligação do TTF-1 à região promotora de PDS - ChIP assay ....29

3.3.9 Clonagem da região $15 \mathrm{~kb}$ a montante da região ATG no gene PDS...............32

3.3.10 Avaliação do conteúdo da proteína pendrina frente ao excesso de iodeto. .33

3.3.11 Localização subcelular da proteína pendrina - Imunofluorescência ..............33

3.3.12 Análise da taxa do efluxo de iodeto em células PCCI3 tratadas com Nal.....34

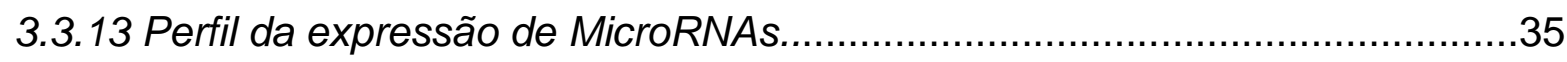

3.4 Análise Estatística .............................................................................. 35 
4 RESULTADOS.

4.1 Efeito da administração de Nal na expressão do mRNA de pendrina...................37

4.2 Avaliação da meia-vida do transcrito de pendrina em células PCCl3...................39

4.3 Efeito da administração de Nal sobre a expressão do mRNA de pendrina em células PCCl3 submetidas ao bloqueio da transcrição gênica....................................40

4.4 Efeito da administração de Nal na expressão do CIC-5 em células PCCI3..........40

4.5 Avaliação da expressão do mRNA do TTF-1 ....................................................

4.6 Avaliação da localização do TTF-1, por imunofluorescência..................................42

4.7 Avaliação da localização subcelular do fator transcricional TTF-1 ........................42

4.8 Avaliação da atividade do promotor de PDS de rato............................................43

4.9 Avaliação da atividade do promotor de PDS humano .........................................44

4.10 Avaliação da ligação do TTF-1 à região promotora de PDS - ChIP assay..........45

4.11 Investigação da região $15 \mathrm{~kb}$ a montante do promotor de PDS em células PCCl3.

4.12 Avaliação da proteína pendrina total frente ao excesso de iodeto - Western Blotting

4.13 Localização subcelular da proteína pendrina - Imunofluorescência......................50

4.14 Avaliação da taxa de efluxo de iodeto em células PCCl3 tradas com Nal.............51

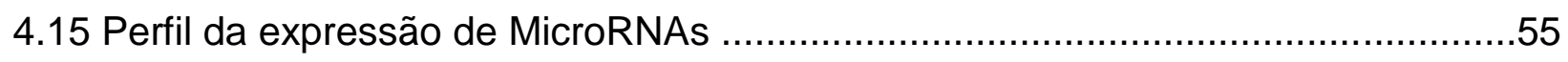

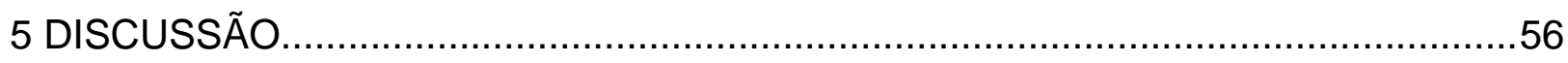

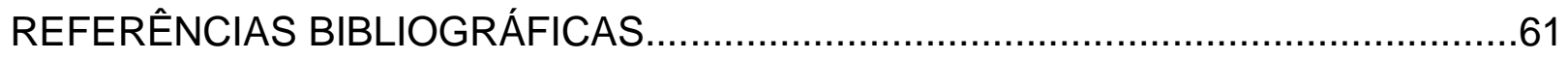

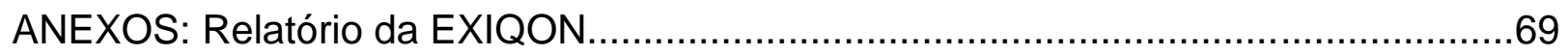




\section{INTRODUÇÃO}

Os principais produtos de secreção tiroidiana são a triiodotironina - T3 e tiroxina-T4, compostos que resultam do acoplamento de duas moléculas iodadas de tirosina. Tais compostos são de grande importância fisiológica, pois modificam a expressão de vários genes/proteínas envolvidos no crescimento, desenvolvimento e processos metabólicos (YEN et al., 2001). Assim, o iodo é fundamental para o organismo, uma vez que a sua deficiência compromete a síntese desses hormônios.

Uma vez ingerido, o iodo é convertido a iodeto no trato gastrointestinal antes de ser absorvido. Quando na corrente sanguínea, o iodeto é transportado para o interior das células foliculares através do co-transportador sódio/iodeto (NIS) presente na membrana basolateral do tirócito (CAVALIERI, 1997; SPITZWEG et al., 2002). Em seguida, o iodeto dirige-se para o lúmen folicular principalmente através da pendrina - um transportador de iodeto/cloreto presente na membrana apical. A oxidação do iodeto e sua organificação ocorrem na superfície apical da célula folicular, sendo essas reações catalisadas pela tireoperoxidase (TPO). A reação utiliza peróxido de hidrogênio $\left(\mathrm{H}_{2} \mathrm{O}_{2}\right)$ gerado pelo sistema gerador de $\mathrm{H}_{2} \mathrm{O}_{2}$, o DUOX (ROYAUX et al., 2000; VAISMAN et al., 2004). A ilustração abaixo mostra a localização dessas proteínas no tirócito (Figura 1).

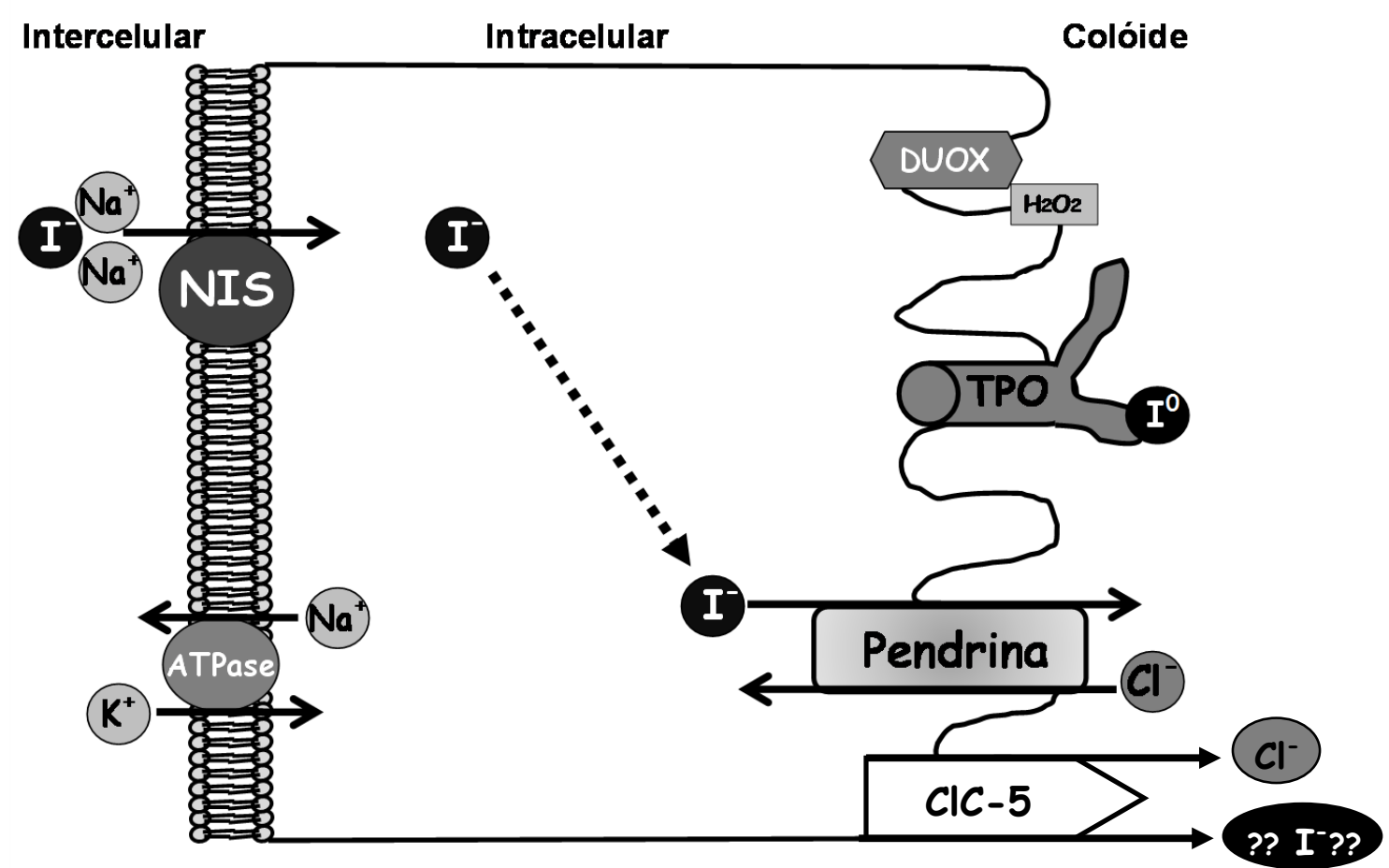


Figura 1- Representação da localização das proteínas envolvildas no transporte e metabolismo de iodeto na célula tiroidiana.

A biossíntese dos hormônios da tiróide depende, portanto, não somente de uma ingestão adequada de iodo, mas também da expressão de diversos genes envolvidos nessa via, que codificam a tireoglobulina (TG), a tireoperoxidase (TPO), o co-transportador sódio/iodeto (NIS), a pendrina (PDS), o sistema gerador de $\mathrm{H}_{2} \mathrm{O}_{2}$ (DUOX) e o receptor do hormônio tireotrófico (TSHR) (SUZUKI et al., 2006).

Sabe-se, todavia, que a ingestão crônica de altas quantidades de iodo pode causar diversos danos na função tiroidiana, como tiroidites, doenças auto-imunes, hipotiroidismo e hipertiroidismo (BURMAN; WARTOFSKY, 2000; ENG et al., 1999; FERREIRA et al., 2005; KNOBEL; MEDEIROS-NETO, 2004; LI et al., 2007; MEDEIROS-NETO, 2009; ZIMMERMANN, 2008). Sabe-se também que, agudamente, a glândula tiróide possui uma capacidade de autorregulação bastante eficiente, que é desencadeada pelo iodeto. Essa autorregulação foi demonstrada por Morton e colaboradores (1944), que observaram que a administração de altas doses de iodeto inibia a síntese dos hormônios tiroidianos. Pouco tempo depois, Wolff e Chaikoff (1948) demonstraram que a organificação do iodeto é bloqueada quando este se encontra em concentrações elevadas no plasma (efeito Wolff-Chaikoff). Estes mesmos autores demonstraram que após determinado período de tempo, apesar da concentração de iodeto plasmático ainda estar elevada, a organificação retomava a sua normalidade. Esse efeito foi denominado Escape do efeito WolffChaikoff.

O Efeito Wolff-Chaikoff e o seu Escape constituem um sistema altamente especializado de autorregulação da tiróide, que a protege dos efeitos deletérios do excesso de iodeto. Algumas patologias da glândula se devem à sua incapacidade de escapar do Efeito Wolff-Chaikoff que a sobrecarga de iodeto exerce sobre a síntese e a liberação dos hormônios tiroidianos, impedindo que a glândula reassuma sua síntese hormonal normal (BURMAN; WARTOFSKY, 2000; DOHÁN et al., 2003; PAVAN et al., 2004). Desta maneira, entender os mecanismos moleculares envonvidos na autorregulação da tiróide é de extrema importância.

Atualmente, aceita-se que o mecanismo responsável pelo efeito Wolff Chaikoff seja a formação de iodolípides, que causariam uma inibição em várias etapas da síntese dos hormônios tiroidianos (PANNEELS et al., 1994; PANNEELS et al., 1996; PEREIRA et al., 1990), já que na presença de bloqueadores da TPO, onde 
não haveria a formação desses compostos, os efeitos supressores do iodo deixam de ser observados (CARDOSO et al., 2002; DENEF et al., 1996); contudo, não se descarta uma ação rápida exercida pelo iodeto per se (CALIL-SILVEIRA et al., 2012; MORAND et al., 2003; SERRANO-NASCIMENTO et al., 2010).

Os mecanismos moleculares envolvidos no Escape, por sua vez, são menos conhecidos e pouco explorados. Braverman e Ingbar (1963) sugeriram que esse escape ocorreria devido a uma diminuição da captação de iodeto, e que esse fenômeno seria intrínseco da glândula, ocorrendo independentemente de TSH (hormônio tireotrófico). Após a clonagem da NIS (DAí et al., 1996), estudos demonstraram que, de fato, o iodeto intracelular desencadeia mecanismos que levam à redução da sua própria captação, bem como do conteúdo do mRNA e da proteína NIS (DOHÁN et al., 2003; ENG et al., 1999, 2001; SERRANONASCIMENTO et al., 2010, 2012).

Recentes estudos in vivo $\mathrm{e}$ in vitro realizados no nosso laboratório evidenciaram que, após o tratamento com iodeto, ocorre diminuição da estabilidade do mRNA de NIS, com consequente redução da taxa de síntese dessa proteína (SERRANO-NASCIMENTO et al., 2010, 2012). A instabilidade ocorre possivelmente devido a uma diminuição do comprimento da cauda poli(A) do transcrito, já que se sabe que a estabilidade bem como a eficiência de tradução de um transcrito estão diretamente relacionadas ao comprimento da sua cauda poli(A) (GOULART-SILVA et al., 2011; ROBINSON, 1988; SERAPHIM et al. 2007).

Desta maneira, cada vez mais fica fortalecida a hipótese de Braverman e Ingbar (1963) de que o Escape adaptativo ocorra, pelo menos em parte, devido a uma inibição de NIS pelo iodeto, causando uma menor captação deste oligoelemento e reduzindo-o a níveis intracelulares incapazes de sustentar o efeito de Bloqueio. Contudo, uma outra possibilidade a ser aventada para explicar o Escape, seria a saída do iodeto da célula para o lúmen folicular, a qual poderia ser desencadeada pelo próprio iodeto. Como comentado anteriormente, o efluxo de iodeto para o colóide se dá principalmente através da pendrina.

Pendrina é um transportador de ânions, codificado pelo gene PDS. É altamente expressa na glândula tiróide, onde realiza a troca de $\mathrm{Cl}-/ \mathrm{l}-$, bem como nos rins e ouvido interno, onde realiza a troca de $\mathrm{Cl}-\mathrm{HCO}-$. Pendrina também é encontrada em outros órgãos como glândula mamária, útero, testículos, placenta e pulmão (LACROIX et al., 2001; NOFZIGER et al., 2011). 
Mutações no gene humano PDS causam a síndrome de Pendred (OMIM 274600), que foi descrita em 1896 pelo médico Vaughan Pendred. Ele foi o primeiro a relacionar o bócio não endêmico de alguns pacientes com a surdez que os mesmos apresentavam. No entanto, havia dificuldades de estudar essa síndrome devido principalmente à apresentação clínica variável entre os pacientes, bem como à ausência de um teste de diagnóstico específico (REARDON; TREMBATH, 1996). A incidência dessa síndrome é de 7,5 a 10 a cada 100.000 indivíduos. Estima-se que seja causa de $\sim 10 \%$ dos casos de surdez hereditária, e que é a forma mais comum de surdez sindrômica (REARDON et al.,1997; CAMPBELL et al., 2001).

Em adição à Síndrome de Pendred, mutações no gene PDS podem ser também responsáveis por um tipo de surdez não sindrômica - NSRD (non-syndromic recessive deafness), onde igualmente pode ocorrer alargamento do aqueduto vestibular (EVA), ou displasia de Mondini (USAMI et al. 1999). A síndrome de Pendred é clinicamente diferenciada da NSRD justamente pela presença de bócio (CAMPBELL et al. 2001; IWASAKI et al, 2006). Mesmo assim, é difícil distinguir a surdez não sindrômica (NSRD) da síndrome de Pendred em crianças, uma vez que o bócio geralmente aparece entre a adolescência e vida adulta. Ainda, o bócio pode variar devido a fatores genéticos e ambientais (BIZHANOVA; KOPP, 2010; KOPP, 1999; SCINICARIELLO et al. 2005; YANG et al. 2005).

A causa do bócio na síndrome de Pendred parece ser a deficiente iodação da TG do lúmen folicular devido a uma taxa reduzida do transporte de iodeto através da membrana apical das células epiteliais da glândula tiróide (REARDON et al., 2000).

Em 1997 Everett e colaboradores clonaram o gene da pendrina. Este se encontra localizado no cromossomo 7q22-31.1, e foi inserido na família SLC26 (transportadores de ânions). Devido à alta similaridade com transportadores de sulfato, foi equivocadamente classificado como tal (EVERETT et al., 1997).

Dois anos depois da clonagem de pendrina, SCOTT e colaboradores (1999), utilizando duas linhagens de oócitos (xenopus laevis oocytes e Sf9), mostraram que sulfato não era carreado pela pendrina. Ao contrário, ela transportava de maneira muito eficiente iodeto e cloreto, independentemente de sódio.

Uma série de estudos funcionais em células transfectadas demonstrou que, de fato, pendrina pode eficientemente transportar iodeto em células de mamíferos, já que possui alta seletividade ao iodeto, quando comparado a outros ânions monovalentes (SHCHEYNIKOV et al. 2008). Estas descobertas, junto com a 
organificação deficiente do iodeto nos pacientes com síndrome de Pendred apontam fortemente para um papel da pendrina em mediar o efluxo apical do iodeto dos tireócitos para a luz do folículo (BIDART et al., 2000; GILLAM et al., 2004; KARNISKI, 2000; ROYAUX et al., 2000; SCOTT; SHCHEYNIKOV et al. 2008; SOLEIMANI et al. 2001; YOSHIDA et al. 2002). A presença de cloreto no lúmen folicular é necessária para que ocorra o efluxo de iodeto pela pendrina, sendo que a estequiometria dessa troca é de 1 lodeto/1 cloreto (SHCHEYNIKOV et al. 2008; YOSHIDA et al., 2004).

Apesar da pendrina ser o principal transportador apontado para realizar 0 efluxo de iodeto, sabe-se que este ocorre por mais de uma via (GOLSTEIN, et al.1992; OHANA et al., 2009; VAN DEN HOVE et al., 2006). O primeiro estudo eletrofisiológico que sugeriu a existência de dois transportadores na porção apical dos tirócitos envolvidos no efluxo de iodeto foi realizado por Golstein e colaboradores, em 1992. O grupo observou que um dos canais possui alta capacidade de transporte de iodeto $(\mathrm{Km} \sim 70 \mu \mathrm{M})$ quando este se encontra em baixa concentração, em relação ao outro $(\mathrm{Km} \sim 33 \mathrm{mM})$. A identidade desses transportadores ainda não foi determinada molecularmente, no entanto cada vez mais estudos sugerem que a pendrina possa ser um desses canais.

Um outro candidato para realizar o transporte de iodeto através da membrana apical de células tiroidianas é o canal de cloreto 5 , o ClC-5. A inativação desse canal em camundongos acarretou sintomas bastante parecidos aos encontrados em pacientes da síndrome de Pendred: presença de bócio eutiroideo e deficiente efluxo de iodeto do tirócito; os animais também apresentaram diminuição da expressão de pendrina (VAN DEN HOVE et al., 2006). O trabalho sugere que o CIC-5 modula a taxa de efluxo apical de iodeto, ou agindo como via alternativa de transporte desse íon, ou regulando a expressão/função de pendrina.

Ainda sobre a possível interrelação entre pendrina e ClC-5, interessante estudo de Senou e colaboradores (2010) demonstrou que a ausência de pendrina em tiróide de paciente com síndrome de Pendred foi acompanhada por aumento da expressão do CIC-5, o que poderia compensar o efluxo deficiente de iodeto.

Apesar de diversos estudos a favor, o papel de pendrina em mediar o efluxo apical de iodeto na tiroide é contestado por alguns grupos devido aos seguintes fatos: 1) a ausência de qualquer disfunção tiroidiana em camundongos knockout para PDS, SLC26A4 (-/-) (CALEBIRO et al., 2010); 2) nem todos os pacientes com 
síndrome de Pendred apresentam disfunção tiroidiana (CAMPBELL et al. 2001); 3) a pendrina possui distinto papel no ouvido e rim, transportando nestes tecidos $\mathrm{Cl}^{-}$ $/ \mathrm{HCO}_{3}{ }^{-}$(ROYAUX et al., 2001; SOLEIMANI et al., 2001); 4) a falta de significativa responsividade de pendrina ao $\mathrm{TSH}$, apesar desse fato ser controverso, como será exposto adiante (MUSCELA et al., 2008; PESCE et al., 2012; ROYAUX et al., 2000).

O trabalho de Calebiro e colaboradores (2010) mostrou que os camundongos knockout SLC26A4 (-/-) não apresentaram qualquer diferença no tamanho e função da glândula tiroidiana, quando comparados aos camundongos normais. No entanto, os autores consideram que mais estudos são necessários para esclarecer as diferenças entre ser humano e camundongo. De fato, a expressão de PDS é diferente em ratos/camundongos e seres humanos. Nos primeiros, a expressão de PDS é mais significativa no rim do que na tiróide (LACROIX et al., 2001; ROYAUX et al., 2001), sugerindo que os roedores possuam mecanismos adicionais de efluxo do iodeto na tiróide.

Quanto ao fato de nem todos os pacientes com síndrome de Pendred apresentarem disfunção tiroidiana, vale ressaltar que mais de 170 mutações em PDS já foram descritas, de maneira que diferentes genótipos acarretam em diferentes fenótipos (DOSSENA et al., 2011b). De fato, as diferentes mutações podem causar diversos impactos na proteína traduzida. A maioria das mutações descritas causa perda parcial ou total da capacidade de pendrina em realizar trocas iônicas (DOSSENA et al., 2011b). No entanto, já foram descritas duas mutações que acarretam em aumento da função de transporte pela pendrina (DOSSENA et al.,2011a). Isso mostra a ampla variabilidade fenotípica encontrada entre os pacientes com síndrome de Pendred (CAMPBELL et al., 2001; SCOTT et al., 2000).

No rim, a Pendrina é expressa também na membrana apical de células intercaladas B. Ela realiza a absorção de $\mathrm{Cl}^{-}$e secreção de $\mathrm{HCO}^{-}$através da troca $\mathrm{Cl}^{\prime} / \mathrm{HCO}^{-}$(SCOTT et al.,1999, 2000; SOLEIMANI et al., 2001). Sua expressão é regulada negativamente pelo $\mathrm{Cl}^{-}$urinário, bem como pelo $\mathrm{pH}$ sanguíneo, aldosterona e angiotensina II (FRISCHE et al., 2003; HAFNER et al., 2008; PECH et al., 2007; QUENTIN et al., 2004; VERLANDER et al., 2003; VALLET et al., 2006). Recentemente, Kim e colaboradores (2009) avaliaram se o iodeto da dieta alteraria a expressão da pendrina, bem como faz o cloreto, e demonstraram que no rim, o iodeto não altera a quantidade ou distribuição de pendrina. 
A pendrina é uma glicoproteína altamente hidrofóbica, composta de 780 aminoácidos. Ela contém três sítios extracelulares supostamente de glicosilação em aspargina (PORRA et al., 2002; ROYAUX et al., 2000), e apresenta uma massa molecular de 110-115 kDa, quando isolada de tiróide humana (PORRA et al., 2002). Tem sido proposto que a pendrina possui 12 domínios transmembrânicos, sendo que ambas as terminações (carboxil e amino) localizam-se no citossol (GILLAM et al., 2004; ROYAUX et al., 2000). Assim como outros membros da família SLC26A, a pendrina contém o chamado domínio STAS (sulfate transporter and antisigma factor antagonist) (ARAVIND; KOONIN, 2000), cuja função exata ainda não foi elucidada, mas que parece estar envolvido na ligação de nucleotídeos e/ou interação com outras proteínas (ARAVIND; KOONIN, 2000; BIZHANOVA et al., 2011; KO et al., 2002; SHARMA et al., 2011). Estudos funcionais de mutações reportadas em pacientes com síndrome de Pendred e EVA indicam que a maioria das mutações no domínio STAS compromete a translocação de pendrina para a membrana, a qual fica retida nos compartimentos intracelulares (EVERETT et al., 1997; GILLAN et al., 2004; PERA et al., 2008; SCOTT et al., 2000; TAYLOR et al., 2002; YOON et al., 2008). Essas mutações promovem uma reduzida ou completa perda de efluxo do iodeto.

A regulação da expressão de pendrina na tiróide ainda é pouco estudada. $O$ TSH, principal hormônio estimulador da expressão dos genes tiroidianos, foi primeiramente descrito como não tendo ação significativa na expressão de mRNA de pendrina (ROYAUX et al., 2000). Neste estudo, células de tiróide de ratos FRTL-5 foram tratadas com componentes que conhecidamente modulam a função tiroideana (TG, lodo, TSH, T3, T4). Analisou-se então a expressão de mRNA de pendrina e outros genes por Northern Blot. Dos vários agentes adicionados ao meio de cultura, apenas a TG aumentou significativamente o mRNA de pendrina (a partir de 3 horas), em contraste com NIS e com a própria TG, que são fortemente inibidas por altas concentrações de TG. Uma possível explicação para a elevada expressão de pendrina é que, uma vez que esta é necessária para assegurar uma quantidade suficiente de iodo no lúmen folicular, seria adaptativamente benéfico seu aumento quando a concentração de TG se eleva.

No entanto, mais tarde, Suzuki e Kohn (2006) demonstraram em células FRTL-5 que o TSH e o iodo em altas concentrações (5 mM) são capazes de aumentar a expressão do mRNA de pendrina, quando na presença de TG. 
Muscella e colaboradores (2008) utilizaram a linhagem de células de tiróide de rato $\mathrm{PCCl} 3$ para investigar ações do TSH e insulina na expressão e translocação de pendrina. Tanto a via da PKA como da PKC convencional, que são ativadas pelo TSH, quando ativadas aumentaram a expressão do mRNA e proteína pendrina. No entanto, apenas a insulina aumentou a translocação da proteína para a membrana. Tal translocação foi vista a partir de 10 minutos da administração de insulina, e parece ocorrer independentemente de PKA, uma vez que o bloqueio da via de sinalização desta kinase não impede a translocação da pendrina. $O$ trabalho mostra ainda que o silenciamento da PKC- $\varepsilon$ com RNAi impediu a translocação de pendrina, indicando que é esta a via ativada pela insulina.

Com o objetivo de investigar se o iodeto poderia exercer alguma regulação em pendrina, e assim elucidar novos mecanismos moleculares envolvidos no Efeito Wolff-Chaikoff e Escape, nosso grupo evidenciou que o tratamento de células $\mathrm{PCCl} 3$ com iodeto acarreta em aumento significativo da expressão do mRNA de pendrina (CALIL-SILVEIRA et al., 2012). Esse efeito ocorre num tempo consideravelmente curto (30 minutos), e persiste até o tempo mais longo do estudo, que foi de 48 horas. $O$ efeito do tratamento com iodeto de sódio também foi evidenciado em nossos estudos in vivo, onde ratos apresentaram elevação da expressão do mRNA da pendrina após receberem injeção intraperitoneal de $2 \mathrm{mg}$ de iodeto (CALILSILVEIRA et al., 2012).

A linhagem $\mathrm{PCCl} 3$ possui vantagens em relação à $\mathrm{FRTL}-5$ por ser mais similar à tiróide nativa, expressando marcadores típicos dessas células. Além disso, é mais sensível a controles endócrinos, condição que é perdida na linhagem FRTL-5. Mesmo assim, ambas as linhagens são imortalizadas, podendo então ter perdido alguns dos mecanismos básicos de controle do ciclo celular (FUSCO et al., 1987; KIMURA et al., 1999; MUSCELLA et al., 2008).

Visando explorar os mecanismos moleculares de agentes regulatórios de pedrina no rim, tiróide e ouvido interno, Adler e colaboradores (2008) examinaram o efeito direto do $\mathrm{pH}$ e da aldosterona na atividade do promotor humano de PDS (hPDS) em células renais (HEK293), de tiróide (LA2) e do ouvido interno (VOT36). O pH ácido diminuiu e o pH alcalino aumentou a atividade do promotor de hPDS nas células renais e do ouvido, mas não exerceu efeito nas células tiroidianas. Por outro lado, a aldosterona causou significativa redução dessa atividade apenas nas células renais, sem efeito nas células do ouvido e tiroidianas. Esses experimentos mostram a 
regulação tecido-específica do gene PDS de maneira bastante coerente com a fisiologia do tecido. Neste estudo ainda foram sugeridas regiões no promotor de PDS responsivas aos Fatores transcricionais tiroidianos 1 e 2 (TTF-1 e TTF-2). Nesse sentido, o TTF-1 foi demonstrado como regulador da expressão de PDS em células de rato FRTL-5, ligando-se na região promotora deste gene (DENTICE et al., 2005). No entanto, não foi encontrada nenhuma homologia significativa entre a região responsiva ao TTF-1 no promotor de PDS de rato descrito por Dentice (2005) com a região correspondente no promotor de hPDS (ADLER et al., 2008).

Interessante estudo de Fuziwara e Kimura (2014) utilizando células PCBRAFV600E-6, que são derivadas de PCCl3 e expressam a oncoproteína BRAFV600F sob tratamento com doxycycline, mostrou que BRAFV600F ativa o clã de miRNA miR17-92, que age inibindo a via de sinalização anti-proliferativa do TGF $\beta$. Eles verificaram que 0 tratamento com 10-5 M de iodeto inibe a ação desse clã de miRNAs, restaurando a sinalização do TGF $\beta$. Considerando que o TGF $\beta$ tem sua via de sinalização inibida em câncer de tiróide (ADORNO et al., 2009; ELOY et al., 2012; MATSUO et al., 2010), os dados deste estudo mostram uma ação protetora do iodo, diminuindo a ação proliferativa da oncoproteína BRAFV600F. Esse estudo mostrou ainda que o iodo per se aumentou especificamente a expressão do miR-20 e miR-92, sugerindo a existência de mecanismos pre-miR específicos dentro do mesmo clã.

Como já comentado, o iodo desempenha um importante papel na função da tiróide, sendo sua ação na regulação da expressão gênica das proteínas envolvidas no metabolismo glândula bastante específica. Como exemplos temos a conhecida inibição que o iodo exerce em NIS (ENG et al., 1999; SERRANO-NASCIMENTO et al., 2010, 2012), e sua ação estimulante na expressão do mRNA de pendrina (CALIL-SILVEIRA, et al., 2012). Considerando esses antecedentes e a escassez de estudos relacionados ao controle dos mecanismos envolvidos no efluxo de iodo do tirócito, é nosso interesse ampliar o conhecimento nessa área buscando compreender o papel da pendrina no processo de autoregulação da função tiroidiana. 


\section{OBJETIVO}

Identificar a pendrina como uma proteína responsiva ao iodo e importante componente da autoregulação da função tiroidiana desencadeada pelo excesso de iodeto intracelular. Para tal, pretendemos:

- Avaliar em células tiroidianas PCCl3 e em ratos Wistar o efeito do excesso de iodeto na expressão do mRNA de pendrina, em curtos períodos de tempo (30 min à $48 \mathrm{~h}$ ).

- Buscar os possíveis mecanismos moleculares envolvidos na regulação da expressão desse mRNA.

- Verificar se o tratamento com iodeto acarreta em mudança na expressão da proteína pendrina, bem como na sua localização no tirócito.

- Analisar se o excesso de iodeto é capaz de regular sua própria saída da célula tiroidiana. 


\section{MATERIAL E MÉTODOS}

\subsection{Estudos in vivo}

Foram utilizados ratos Wistar (Rattus norvegicus albinus) de aproximadamente $200 \mathrm{~g}$, provenientes do biotério do Instituto de Ciências Biomédicas da USP, onde foram mantidos sob condições padronizadas de temperatura ambiental $\left(23 \pm 2{ }^{\circ} \mathrm{C}\right)$ e ciclo claro/escuro (12/12 h diárias). A água e alimentação foram fornecidas ad libitum. Os animais foram então divididos nos seguintes grupos experimentais:

- Grupo Controle (C): Animais que receberam injeção de salina i.p. e que foram sacrificados após 30 min, 1, 24 e 48 h da mesma (C 30 min, C 1 h, C 24 h e C48 h).

- Grupo lodo (I): Animais que receberam injeção i.p. de $2 \mathrm{mg}$ de iodeto de sódio (Eng et al., 1999; Serrano-nascimento et al., 2010), e foram sacrificados após 30 min, 1, 24 e 48 h (I 30 min, I 1 h, I 24 h e I 48 h).

- Grupo Perclorato $(\mathbf{I}+\mathbf{P})$ : Ratos submetidos a uma injeção ip de iodeto de sódio (Nal: $2 \mathrm{mg})$ concomitante a injeção de perclorato de sódio $\left(\mathrm{NaClO}_{4}: 2\right.$ $\mathrm{mg}$ ) e sacrificados após $30 \mathrm{~min}$. O perclorato inibe a entrada do iodeto na célula tiroidiana, por competir com ele pelo sítio em NIS.

A análise da expressão do mRNA foi feita pela técnica do PCR em Tempo Real (LIVAK e SCHMITTGEN, 2001), enquanto a expressão de proteína pela técnica do Western Blotting (MACPHEE, 2010).

\subsection{Estudos in vitro}

Utilizamos a linhagem celular de tiróide normal de rato PCCl3. As células foram cultivadas e mantidas em meio HAM F12 contendo 5\% de soro fetal bovino (NGS; Life Technologies, NY, U.S.A.), com $1 \mathrm{mU} / \mathrm{ml}$ de TSH, $10 \mu \mathrm{g} / \mathrm{ml}$ de insulina, 5 $\mu \mathrm{g} / \mathrm{ml}$ de transferrina e $10 \mathrm{ng} / \mathrm{ml}$ de hidrocortisona e os antibióticos penicilina (100 $\mathrm{U} / \mathrm{ml}$ ) e ampicilina ( $10 \mu \mathrm{g} / \mathrm{ml}$ ), em atmosfera umidificada constituída de $5 \%$ de $\mathrm{CO}_{2}$ e $95 \%$ de ar, a $37{ }^{\circ} \mathrm{C}$. As subculturas dessas células foram feitas em placas de 6 poços $(34,8 \mathrm{~mm})$ e mantidas nas mesmas condições descritas acima até atingirem 
$70 \%$ de confluência, quando foi adicionado $10^{-3} \mathrm{M}$ de $\mathrm{Nal}$ ao meio de cultura de 3 poços, sendo os 3 poços restantes considerados como controle. Os experimentos foram realizados em triplicata, e as células permaneceram neste meio durante 30 min, 1 h, 24 h e 48 h após a adição ou não de Nal. Igualmente ao modelo in vivo, adicionamos um grupo I + $\mathrm{P} 30 \mathrm{~min}$.

A análise da expressão do mRNA dos estudos in vitro também foi feita pela técnica do PCR em Tempo Real, enquanto a expressão de proteína pela técnica do Western Blotting.

\subsection{Procedimentos}

\subsubsection{Avaliação da expressão do mRNA de pendrina frente ao excesso de iodeto.}

A extração do RNA total foi baseada na metodologia guanidina-fenolclorofórmio (MANIATS et al., 1989). Após reação de transcrição reversa, utilizando 1 $\mu l$ de enzima (200 U/ $\mu$ l) M-MLV Reverse Transcriptase (Promega), seguiu-se a reação de PCR em Tempo Real. Para tanto, $1 \mu$ de produto da reação de transcrição reversa foi utilizado em $10 \mu \mathrm{l}$ de reação de Real Time PCR contendo $200 \mathrm{nM}$ de cada par de primers designados para os genes de interesse.

As sequencias dos primers foi obtida pelo programa Primer3, desenvolvido pelo Instituto Médico Howard Hughes e pelo National Institutes of Health (http://bioinfo.ut.ee/primer3-0.4.0/). A Beta Actina foi usada como gene constitutivo.

Seguem os primers utilizados para a reação:

Pendrina:

sense: 5' - TCC TCT TGA ACT GAT GGA AGC A - 3'

Antisense: 5' -CCA GGT TCT GCC TAG CAG TC - 3'

\section{Beta Actina:}

sense: 5' - AAG ATT TGG CAC CAC ACT TTC TAC A - 3'

Antisense: 5' - CGG TGA GCA GCA CAG GGT - 3'

Avaliamos também a expressão do mRNA do canal de cloreto $\mathrm{ClC}-5$ frente ao 
mesmo tratamento com iodeto. Seguem os primers utilizados para essa reação:

\section{CIC-5:}

sense: 5' - AAG TGG ACC CTT GTC ATC AA - 3'

Antisense: 5' - ACA GGA TGT TCC CAC AG - 3'

A reação de PCR em tempo real foi realizada em aparelho Corbett (Corbett Research, Sydney, Australia) nas seguintes condições: $50^{\circ} \mathrm{C}$ por 2 min, $95^{\circ} \mathrm{C}$ por 5 min, e 40 repetições de um ciclo de $95^{\circ} \mathrm{C}$ por $20 \mathrm{~s}, 60^{\circ} \mathrm{C}$ por $1 \mathrm{~min}, 72{ }^{\circ} \mathrm{C}$ por $15 \mathrm{~s}$. Os resultados foram analisados pelo programa Rotor-Gene 6000 Series Software 1.7. A reação de cada amostra foi realizada em duplicata. Para as análises quantitativas, os resultados foram calculados usando o método $2^{-\Delta \Delta C t}$ (LIVAK e SCHMITTGEN, 2001).

\subsubsection{Avaliação da meia-vida do transcrito de pendrina}

Uma vez que a actinomicina $D$ causa um bloqueio da transcrição gênica (SOBELL, 1985), esses experimentos permitem avaliar se a administração de Nal altera a expressão gênica da pendrina por mecanismos transcricionais ou póstranscricionais. Para tanto, foi adicionado ao meio de cultura de todos os poços $1 \mu \mathrm{M}$ de actinomicina D. As células foram mantidas nestas condições durante 1 hora, quando então 3 poços foram tradados com 10-3 M de Nal e 3 poços foram considerados como controle. As células permaneceram neste meio durante $30 \mathrm{~min}$ ou $6 \mathrm{~h}$. A análise da expressão gênica foi feita também pela técnica de PCR em Tempo Real. A partir desses resultados, foi construída a curva de decaimento do transcrito de pendrina de células tratadas e não tratadas com iodeto de sódio, conforme demonstrado em Resultados.

\subsubsection{Avaliação da expressão do mRNA do fator transcricional tiroidiano TTF-1}

O procedimento foi o mesmo para a análise do mRNA de pendrina, descrita acima. Foram utilizados os mesmos tempos de tratamento com Nal: 30 min, 1, 24 e 48 horas. As reações também foram normalizadas com a Beta Actina, como descrito acima.

Primers utilizados para a reação: 


\section{TTF-1:}

sense: 5' - ACC TTA CCA GGA CAC CAT GC - 3'

Antisense: 5' - TTC TTG CTC ACG TCC CCC AG - 3'

\subsubsection{Avaliação, por imunofluorescência, da distribuição celular do fator transcricional TTF-1}

Para este estudo, células PCCl3 cresceram sobre lamínulas e depois de sedimentadas, receberam tratamento com Nal durante $30 \mathrm{~min}, 1,24$ e 48 horas. As células foram então lavadas $3 \mathrm{X}$ com PBS/CM (PBS contendo $\mathrm{CaCl} 20,1 \mathrm{mM}$ e MgCl2 $1 \mathrm{mM}$ ) e fixadas com 4\% de paraformaldeído em PBS por $20 \mathrm{~min}$ em temperatura ambiente, e então lavadas, novamente, com PBS/CM. Seguiu-se a permeabilização das células com $0,1 \%$ de Triton em PBS/CM contendo 0,1\% BSA (PBS/CM/TB) por $10 \mathrm{~min}$, a temperatura ambiente. Posteriormente, as células foram submetidas a lavagem com PBS/CM por $10 \mathrm{~min}$, à temperatura ambiente. Fez-se a incubação das células com anticorpo anti-TTF-1 (Santa Cruz, sc-13040), na diluição 1:200 em PBS/CM/TB, por $2 \mathrm{~h}$, à temperatura ambiente. Após a incubação, as células foram lavadas, e incubadas com anticorpo secundário apropriado (anti-rabbit FITC, 1:100). A disposição da proteína na célula, bem como sua expressão foi analisada pelo sinal imunofluorescente emitido pelo anticorpo secundário, visualizada em microscopia confocal (X400).

\subsubsection{Avaliação da localização subcelular do fator transcricional TTF-1}

Para avaliar o conteúdo de TTF-1 no citoplasma e núcleo, antes e após o tratamento com excesso de iodo, o que nos dará informações sobre o efeito deste tratamento na migração do Fator Transcricional para o núcleo, foi feito um fracionamento celular para isolamento da porção nuclear e citoplasmática das células. As células cresceram em frascos de $75 \mathrm{~cm}^{2}$ e após tratamento com Nal, foram removidas por raspagem com $1 \mathrm{~mL}$ de PBS. As amostras foram então submetidas a centrifugação e o pellet ressuspendido em $400 \mu \mathrm{l}$ do Tampão $A$ (HEPES, KCl, EDTA, NP-40, DTT e PMSF). Após 30 min no gelo, as amostras foram homogeneizadas e centrifugadas a $9.300 \mathrm{rpm}$ por $3 \mathrm{~min}$. O sobrenadante, que corresponde à fração protéica citoplasmática, foi recuperado e armazenado. $O$ 
precipitado foi então ressuspendido em $50 \mu \mathrm{l}$ do Tampão C (HEPES, glicerol, $\mathrm{NaCl}$, $\mathrm{MgCl}_{2}$, EDTA, DTT e PMSF), e após manutenção no gelo durante $30 \mathrm{~min}$, as amostras foram homogeneizadas vigorosamente. Após nova centrifugação (10.000 rpm por $5 \mathrm{~min}$ ), recuperou-se o sobrenadante contendo a fração protéica nuclear. Seguiu-se a quantificação por meio de Bradford e Western blotting de ambas as frações. A diluição do anticorpo primário anti-TTF-1 foi de 1:5000 (Santa Cruz, sc13040), assim como do anticorpo secundário anti-rabbit (Jackson Immuno Research): 1:5000.

\subsubsection{Avaliação da atividade do promotor de PDS de rato}

Para avaliar a atividade da região promotora do gene PDS frente ao excesso de iodo, utilizamos o plasmídeo pGL3-básico (Promega) (DENTICE et al., 2005), que contem a sequência correspondente ao promotor de pendrina do rato $(3,074 \mathrm{~kb}) \mathrm{a}$ montante do gene correspondente à luciferase, o qual foi gentilmente cedido pelo $\mathrm{Dr}$ Salvatore (Universidade de Nápoles, Itália). Bactérias competentes foram transformadas com esse plasmídeo, e após crescimento das mesmas, foi feita a purificação do plasmídeo pela técnica de mini-prep, como descrito pelo fabricante (Sigma-Aldrich).

Para confirmar se os plasmídeos obtidos eram de fato os de interesse, eles foram digeridos com a enzima de restrição Sall, que reconhece o seguinte sítio de restrição G TCGA C, que é encontrado apenas uma vez no vetor pGL3-basico, como pode ser obervado na figura 2 .

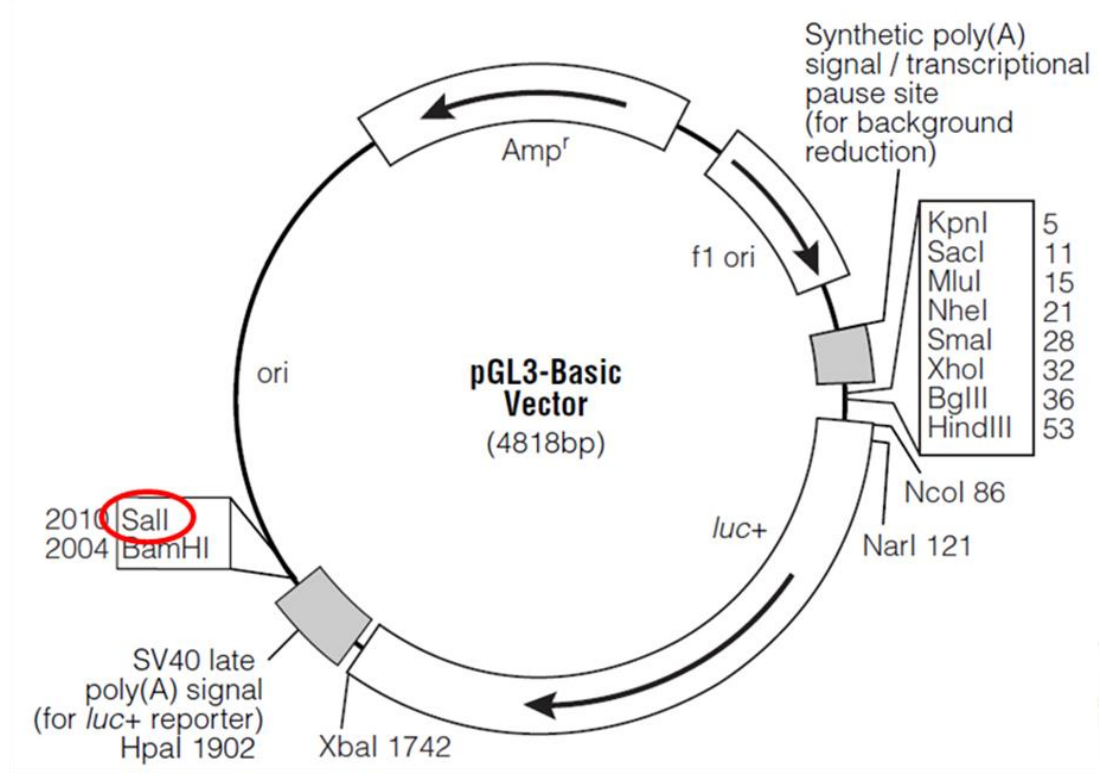


Figura 2 - Esquema do plasmídeo pGL3-basico, que recebeu a sequência correspondente ao promotor de PDS de rato. Pode-se observar que em apenas uma região ha sítio de corte para a enzima de restrição Sall.

Após confirmação de que o plasmídeo possuía o tamanho esperado, células PCCl3 foram transfectadas utilizando lipofectamina (Invitrogen), e fez-se então a análise da expressão do gene da luciferase frente ao tratamento com iodo.

\subsubsection{Avaliação da atividade do promotor de PDS de humano (hPDS)}

Para esse estudo, dois fragmentos de diferentes tamanhos da região promotora do gene hPDS foram testados: um que abrange $2.0 \mathrm{~kb}$ e outro $4.1 \mathrm{~kb}$ a montante ao ATG. Os plasmídeos pGL3-basico contendo tais fragmentos foram gentilmente cedidos pelo Dr. Peter Kopp (Northwestern University, Chicago, Estados Unidos). Células $\mathrm{PCCl} 3$ foram transfectadas com esses plasmídeos, para a análise da expressão do gene da luciferase frente ao tratamento com iodeto.

\subsubsection{Avaliação da ligação do fator transcricional TTF-1 à região promotora de PDS - ChIP assay}

A imunoprecipitação da cromatina (Chromatin immunoprecipitation - ChIP) foi utilizada para investigar a interação proteína-DNA na célula (COLLAS, 2010). Em resumo, a metodologia consiste nas etapas: (1) Cross-link entre proteínas e DNA, (2) lise das células, (3) fragmentação da cromatina através de sonicação ou restrição enzimática, (4) imunoprecipitação com anticorpo específico, (5) purificação do DNA contido no imunoprecipitado, (6) análise desse DNA. Essas etapas estão representadas na figura 3. 


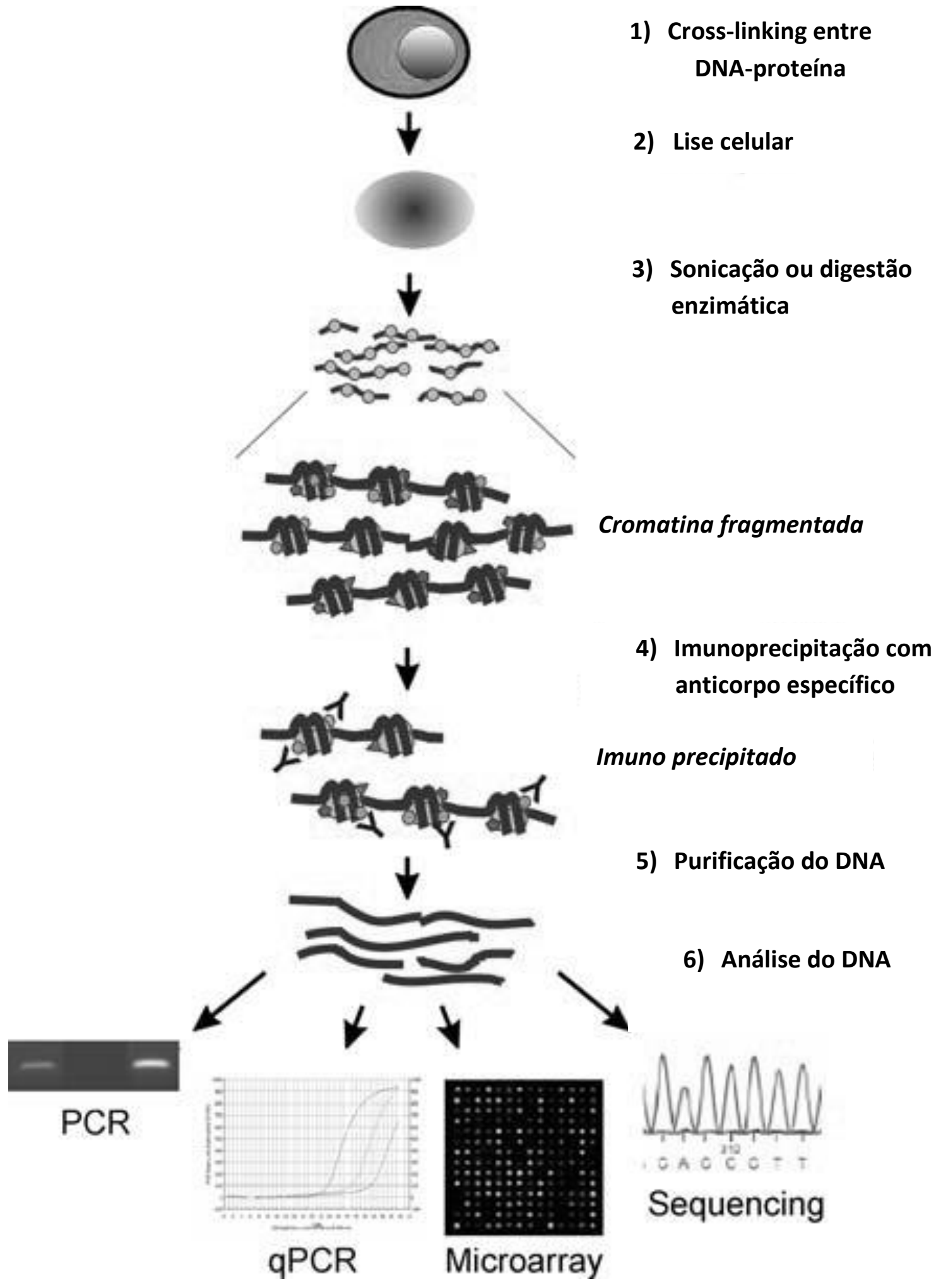

Figura 3 - Esquema do ensaio de Imunoprecipitação da Cromatina (ChIP assay). As etapas da metodologia estão numeradas de 1 - 6 (Imagem modificada de Collas, 2010). 
As células $\mathrm{PCCl} 3$ foram submetidas a uma etapa inicial de cross-link com formaldeído $1 \%$ a temperatura ambiente. Essa etapa visou ligar covalentemente proteínas às suas sequências de DNA alvos. Após fixação, as células foram lavadas em PBS, centrifugadas, ressuspendidas em Tampão de lise SDS 1\%. A cromatina foi fragmentada em sonicador (Microson ${ }^{\mathrm{TM}}$ Ultrasoni Cell Disruptor) por 8 pulsos a $40 \%$ da potência máxima. Em seguida, $100 \mu \mathrm{L}$ da amostra foram diluídos em Tampão de Diluição acrescido de coquetel anti-protease. Para limpar o lisado, foi adicionado proteína A-Sepharose 6MB (Amersham-Pharmacia, Uppsala, Suécia) saturada com DNA de esperma de salmão em cada amostra. Seguiu-se incubação por 1 hora a $4 \stackrel{\circ}{\circ}$ em rotação. Após este período, as esferas de proteína $A$ foram precipitadas por centrifugação a $3000 \times \mathrm{g}$ por $1 \mathrm{~min}$ a $4 \stackrel{\circ}{ } \mathrm{C}$. Subsequentemente, 10 $\mu \mathrm{L}$ de cada amostra foram estocados para servir como referência da quantidade total de DNA (Input) em cada condição. O sobrenadante foi transferido para tubos novos, e incubados overnight à $4 \stackrel{\circ}{\circ} \mathrm{C}$ sob rotação com $1 \mu \mathrm{g}$ do anticorpo de interesse antiTTF-1 (produzido em coelho) (H-190, sc-13040) (Santa Cruz Biotechnology, CA, USA). Após incubação, Adicionou-se $60 \mu \mathrm{L}$ de Proteína A-sepharose por 1 hora à 4 -C sob rotação. A seguir, as esferas de Proteína A-sepharose (ligadas ao complexo Anti TTF-1/ proteína/DNA) foram precipitadas por centrifugação (3000 x g por 1 min a $\left.4 \stackrel{\circ}{ }{ }^{\circ}\right)$ ) e lavadas com os seguintes tampões: Tampão hipotônico, Tampão hipertônico, Tampão de LiCl e Tampão TE. Foi utilizado $1 \mathrm{~mL}$ de cada tampão para cada lavagem, seguida de centrifugação após cada uma delas (3000 x g por 1 min a $4 \stackrel{\circ}{ } \mathrm{C}$ ). Após lavagens, o complexo anticorpo/antígeno/DNA foi eluído com tampão $1 \%$ SDS. Em seguida o cross-link foi revertido em solução de $\mathrm{NaCl} 5 \mathrm{M}$ a $65{ }^{\circ} \mathrm{C}$ overnight. Posteriormente as amostras foram incubadas com RNAse, seguidas de incubação com solução de Proteinase K. Após extraído e purificado por fenol:clorofórmio, o O DNA foi submetido a analise por PCR quantitativo.

As duas regiões testadas por Dentice e colaboradores (2005), visando analisar se havia ligação de TTF-1 nas mesmas, foram testadas em nosso estudo (PDS1 e PDS3). Adicionalmente, utilizamos uma terceira região para análise se havia ligação de TTF-1 (PDS2). Os primers utilizados para sintetizar tais regiões estão descritos abaixo: 
PDS1- região $3.0 \mathrm{~kb}$ upstream da região ATG no gene PDS (região promotora):

Sense: 5' - GTCATAGGGAGACCATAAGACAG - 3'

Antisense: 5' - AGAACTCAACCATCACTCTGTCA - 3'

PDS2- região 299 pb upstream da região ATG no gene PDS (região promotora):

Sense: 5' - ACCCAGTCCAACACCCAAG - 3'

Antisense: 5' - CGACGAGGGAAGACACTCAG - 3'

PDS3- região $15.0 \mathrm{~kb}$ upstream da região ATG no gene PDS (upstream da região promotora):

Sense: 5' - GATCCTGTGGTTTTGGTGCTGC - 3'

Antisense: 5' - GTGGCATCTCTGGGTTGGTCC - 3'

\subsubsection{Clonagem da região $15 \mathrm{~kb}$ a montante da região ATG no gene PDS}

Uma vez que no ensaio de Chip, descrito acima, apenas a região abrangida pelos primers PDS3 foi amplificada, procuramos fazer a clonagem deste fragmento, que corresponde à região $15.0 \mathrm{~kb}$ a montante ao ATG no gene PDS.

Foram construídos os mesmos primers PDS3 descritos para o experimento de Chip, com a inclusão de sítios de restrição para as enzimas Xhol e Hindlll, bem como dos respectivos overhangers ótimos para cada enzima (https://www.neb.com/tools-and-resources/usage-guidelines/cleavage-close-to-theend-of-dna-fragments). Os primers utilizados para a reação estão descritos abaixo:

Sense: 5' CCG GCT CGA GGA TCC TGT GGT TTT GGT GCT GC 3'

Anti sense: 5' CCG GAA GCT TGT GGC ATC TCT GGG TTG GTC C 3'

O fragmento de interesse foi construído através da PCR, e o produto foi purificado, utilizando-se kit da Promega. Em seguida, o fragmento de interesse e o plasmídeo $\mathrm{pGL3-basic} \mathrm{foram} \mathrm{submetidos} \mathrm{à} \mathrm{reação} \mathrm{de} \mathrm{restrição} \mathrm{com} \mathrm{as} \mathrm{enzimas} \mathrm{Xhol}$ (C`TCGA G) e HindIII, (A`AGCT T) como descrito pelo fabricante (Promega). Fez-se 
então a reação de ligação entre o plasmídeo e a sequência construída, utilizando a enzima T4 ligase (Fermentas). Bactérias competentes foram transformadas com esse plasmídeo contendo a região 15kb upstream ATG, e após crescimento das mesmas, foi feita a purificação do plasmídeo pela técnica de mini-prep (SigmaAldrich). Confirmamos a presença da região de interesse no plasmídeo através de sequenciamento. Em seguida, células $\mathrm{PCCl} 3$ foram transfectadas com esses plasmídeos a fim de verificar se a região $15.0 \mathrm{~kb}$ upstream ao ATG do gene PDS seria capaz de, sob o tratamento com $\mathrm{Nal}$, ativar a expressão do gene da luciferase.

\subsubsection{Avaliação do conteúdo total da proteína pendrina frente ao excesso de iodeto.}

Células/tecido foram homogeneizados em tampão RIPA (Tris $50 \mathrm{mM}, \mathrm{pH}$ 7,4; $\mathrm{NaCl} 150$ mM, Nonidet P-40 1\%; Sodium Deoxycholato 1\%; EDTA $1 \mathrm{mM}$ e SDS $0,1 \%$ ) e inibidor de proteases a $10 \%$. Após a quantificação da concentração de proteínas do homogeneizado, utilizando-se o método de Bradford, $40 \mu \mathrm{g}$ de cada amostra foram depositados em SDS-PAGE $8 \%$. Posteriormente, foi feita a transferência das proteínas para uma membrana de PVDF. A mesma foi, então, bloqueada com solução de bloqueio (leite 5\%) à temperatura ambiente (TA) por $1 \mathrm{~h}$. Seguiu-se a incubação overnight $\left(4{ }^{\circ} \mathrm{C}\right)$ da membrana com anticorpos policlonais específicos: anti-PDS e Beta Actina, sendo este último utilizado para a normalização. Ao final da incubação com anticorpo primário, a membrana foi lavada com solução de lavagem, em TA, e incubada com anticorpo secundário (conjugado com peroxidase) por $1 \mathrm{~h}$ à TA, e, a seguir, lavada $4 \mathrm{X}$, por $10 \mathrm{~min}$, com solução de TBSTween $0,05 \% \quad(50 \mathrm{mM}$ Tris, $150 \mathrm{mM} \mathrm{NaCl}, \mathrm{pH} 7.4)$. A membrana foi tratada com reagentes quimioluminescentes (ECL-Amershan) e, então, exposta a um filme autoradiográfico, sendo a análise densitométrica das bandas realizada por meio do software Image J (National Institutes of Health, USA).

\subsubsection{Localização subcelular da proteína Pendrina - Imunofluorescência}

Para este estudo, células $\mathrm{PCCl} 3$ cresceram sobre lamínulas e depois de sedimentadas, receberam tratamento específico, conforme especificado adiante. As células foram, então, lavadas 3X com PBS/CM (PBS contendo CaCl2 0,1 mM e $\mathrm{MgCl} 21 \mathrm{mM}$ ) e fixadas com 4\% de paraformaldeído em PBS por 20 min em TA, e 
lavadas, novamente, com PBS/CM. Seguiu-se a permeabilização das células com 0,1\% de Triton em PBS/CM contendo $0,1 \%$ BSA (PBS/CM/T) por $10 \mathrm{~min}$, a TA. Posteriormente, as células foram submetidas a lavagem com PBS/CM por $10 \mathrm{~min}$, à TA. Fez-se a incubação das células com anticorpo anti-Pendrina, diluído em $\mathrm{PBS} / \mathrm{CM} / \mathrm{T}$ (1:200), por $2 \mathrm{~h}$, à TA. Após a incubação, as células foram lavadas, e incubadas com anticorpo secundário apropriado, na diluição 1:100, por $1 \mathrm{~h}$. à TA. A distribuição da proteína na célula, bem como sua expressão foi analisada pelo sinal imunofluorescente emitido pelo anticorpo secundário.

\subsubsection{Análise da taxa do efluxo de iodeto em células PCCl3 sob tratamento com Nal}

Esse estudo foi realizado em duas etapas. Primeiramente, foram feitos experimentos em que as células foram tratadas por curtos períodos de tempo com Nal. Em seguida, partimos para os experimentos em que as células foram tratadas por tempos mais longos. Importante comentar que, devido a forte inibição de NIS pelo iodeto, quanto mais longo o tratamento com $\mathrm{Nal}$, menos iodeto entra na célula, e consequentemente menos sai. Para contornar essa questão, o experimento de efluxo foi realizado de maneira a calcular a taxa de efluxo em \%, como descrito nos parágrafos abaixo.

Após tratamento com $10^{-3} \mathrm{M}$ de Nal por 1, 2, 4 e 6 horas, as células foram incubadas por $30 \mathrm{~min}$ em $500 \mu \mathrm{l}$ de meio puro pré-aquecido $\left(37^{\circ} \mathrm{C}\right)$ contendo $\mathrm{Na} \mathrm{I}^{125}$ (20 mCi/mmol). Subsequentemente, as células foram lavadas com PBS aquecido e incubadas com meio puro contendo $1 \mathrm{mM}$ de perclorato, como objetivo de inibir a captação de iodeto pela NIS. Após 90 segundos nessa condição o meio foi retirado, reservado e substituído por novo meio contendo perclorato, que foi deixado por 60 segundos. Esse processo foi repetido mais 2 vezes, de maneira que as respectivas amostras de meio reservadas foram chamadas de T1, T2 e T3. Em seguida, as células foram lisadas pela adição de PBS contendo Triton 1\%. Essa fração foi também reservada.

O conteúdo de iodeto foi determinado pela radiação contida em cada uma das amostras (T1, T2, T3 e lisado). A medição da radiação foi feita em contador Gamma. A taxa do efluxo foi medida como descrito abaixo:

A soma de $\mathrm{T} 1+\mathrm{T} 2+\mathrm{T} 3$ + lisado foi considerado o total de iodeto radioativo que foi captado pelas células durante o experimento. Esse valor foi considerado 
como $100 \%$. Com isso, foi possível calcular a taxa de efluxo em cada um dos tempos T1, T2 e T3 dos diferentes grupos, independentemente do fato de NIS estar inibida pelo tratamento prévio com iodeto.

A concentração de DNA de cada placa foi medida para normalização.

Tempos longos de tratamento com iodo: 12, 24 e $48 \mathrm{~h}$

Devido à expressiva inibição de NIS pelo iodeto, para os tempos longos de tratamento foi utilizado $10^{-3} \mathrm{M}$ de Nal já contendo $\mathrm{Na} \mathrm{I}^{125}(20 \mathrm{mCi} / \mathrm{mmol})$. Buscamos com isso evitar a falta de $1^{125}$ dentro das células no momento do experimento, uma vez que após $24 \mathrm{~h}$ de tratamento com Nal, a atividade de NIS está drasticamente reduzida, e $\circ I^{125}$ poderia não ser captado para análise. As células foram então tratadas por 12, 24 e 48 horas. O grupo controle recebeu o meio contendo $10^{-3} \mathrm{M}$ de iodeto e $\mathrm{Na}{ }^{125}$, por 30 minutos, antes do experimento ser iniciado. Subsequentemente, as células foram lavadas com PBS aquecido e incubadas com meio contendo $1 \mathrm{mM}$ de perclorato pelos mesmos tempos descritos nos experimentos de tempos curtos (T1, T2 e T3). A taxa de efluxo foi determinada conforme descrito nos experimentos de tempos curtos.

\subsubsection{Perfil de expressão de MicroRNAs}

Para este ensaio foi feito um experimento piloto em triplicata. Células PCCl3 foram tratadas ou não com $10^{-3} \mathrm{M}$ de iodeto por 24 horas. Subsequentemente, os microRNA foram isolados utilizando o kit miRNeasy Mini Kit (Qiagen, Hilden, Germany), de acordo com instruções do fabricante. Após avaliação da integridade do RNA em gel de agarose $1 \%$, as amostras foram enviadas para a empresa EXIQON (Dinamarca), onde foi realizado o ensaio para análise do perfil de expressão de miRNA miRCURYTM LNA Array microRNA profiling services. Um relatório contendo os detalhes da metodologia, bem como os resultados analisados, foi enviado pela empresa através de e-mail (Anexo 1).

\subsection{Análise Estatística}

Todos os dados numéricos foram expressos como média \pm erro padrão da média $(x \pm S E M)$ dos valores obtidos em cada um dos procedimentos, e comparados através da análise de UNPAIRED $t$ TEST. O teste de análise de variância de uma via (one-way ANOVA) seguido do pós-teste Student-Newman-Keuls, foi utilizado 
quando necessário. (Package: Prism Graph Pad - Version: 5.0). A significância estatística foi definida pelos valores de $P<0,05$. 


\section{RESULTADOS}

\subsection{Efeito da administração de Nal na expressão do mRNA de pendrina}

Os valores obtidos de todos os grupos controle foram reunidos e estão apresentados em um único grupo, uma vez que exibiram valores semelhantes entre si.

A figura 4 mostra que o conteúdo de mRNA de pendrina de tiroide de ratos aumentou significativamente com a administração de $\mathrm{Nal}$ (de 30 min a 48 h), comparado com o grupo controle (CALIL-SILVEIRA et al., 2012). Resultados similares, ou seja, aumento do conteúdo de transcritos de pendrina em resposta ao iodo, foram obtidos em células PCCI3, (figura 5) (CALIL-SILVEIRA et al., 2012).

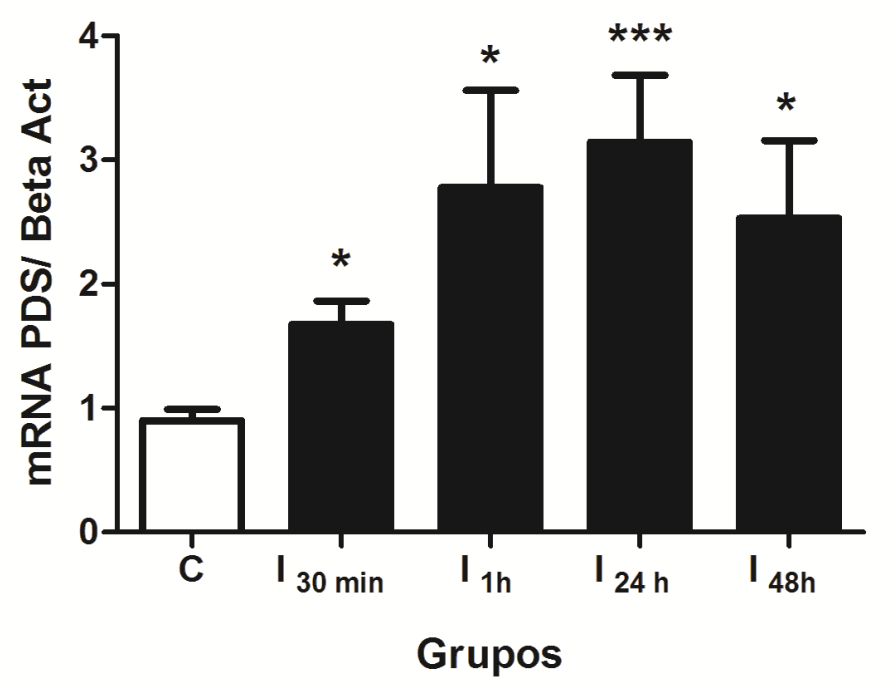

Figura 4 - Avaliação do conteúdo total de mRNA de pendrina (PDS) em tiróide de ratos tratados com excesso de $\mathrm{Nal}(2 \mathrm{mg} / 0,5 \mathrm{ml}$ salina) por $30 \mathrm{~min}, 1,24$ e $48 \mathrm{~h}$.. Os valores obtidos referentes à expressão do mRNA de PDS foram normalizados pela expressão do mRNA de beta-actina (gene constitutivo), por PCR em Tempo Real. Os dados encontram-se representados como média \pm SEM. Foram realizados 3 experimentos, sendo utilizados pelo menos 3 ratos por grupo. ${ }^{*} p<0,05 ;{ }^{* * *} p<0,001$ vs $C$. Análise de variância (ANOVA) de uma via seguida de pós-teste com Student-Newman-Keuls. 


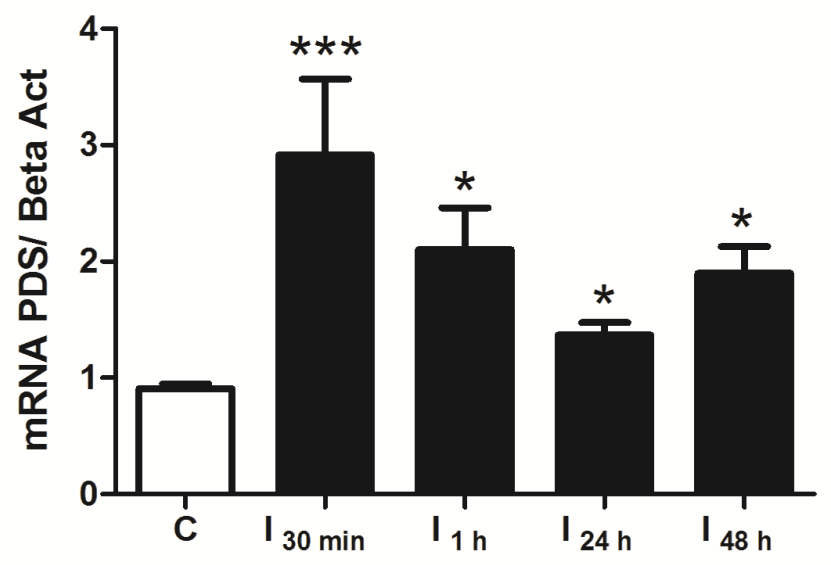

Grupos

Figura 5 - Avaliação do conteúdo total de mRNA de pendrina (PDS) de células PCCl3 tratadas ou não com excesso de $\mathrm{Nal}\left(10^{-3} \mathrm{M}\right)$. Os valores obtidos referentes à expressão do mRNA de PDS foram normalizados pela expressão do mRNA de beta-actina (gene constitutivo), por PCR em Tempo Real. Os dados encontram-se representados como média \pm SEM. Foram realizados 3 experimentos, sendo o $n=3$ /grupo/experimento. ${ }^{*} p<0,05$; ${ }^{* * *}$ $p<0,001$ vs $C$. Análise de variância (ANOVA) de uma via seguida de pós-teste com StudentNewman-Keuls.

Com o objetivo de averiguar se o efeito observado era desencadado pelo iodeto intracelular, experimentos com perclorato (conhecido competidor do iodeto pelo sítio em NIS) foram realizados. O aumento do mRNA de pendrina observado quando os ratos e células receberam $\mathrm{Nal}$ durante $30 \mathrm{~min}$ foi prevenido pelo tratamento concomitante com perclorato (figura 6 A e B) (CALIL-SILVEIRA et al., 2012).

A

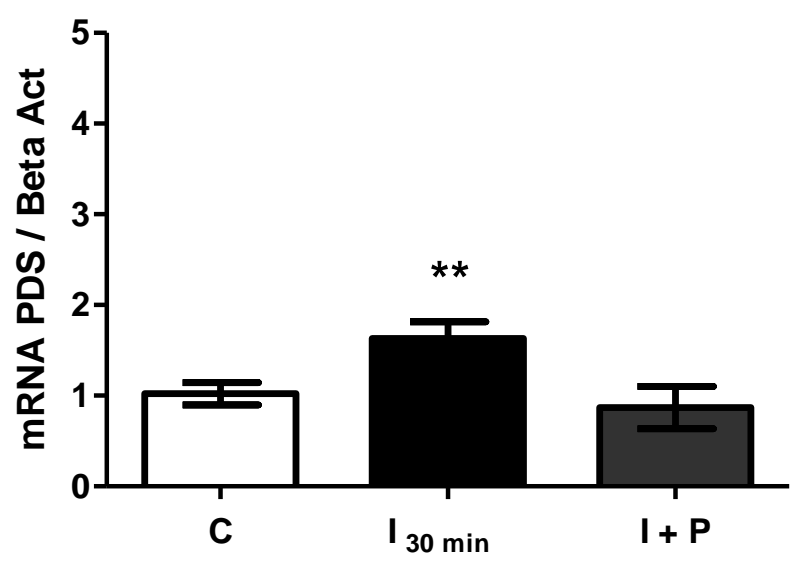

Grupos
B

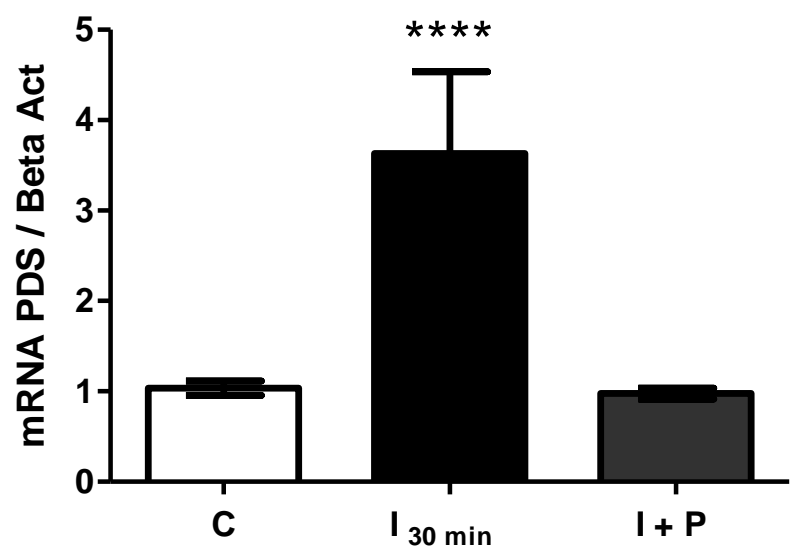

Grupos

Figura 6 - Avaliação do conteúdo de mRNA de pendrina (PDS) de tiroide de ratos (A) e de células PCCl3 (B) tratadas (I $30 \mathrm{mim}$ ) ou não $(\mathrm{C})$ com excesso de $\mathrm{Nal}\left(10^{-3} \mathrm{M}\right)$ ou com iodo mais perclorato $(\mathrm{I}+\mathrm{P})$ por $30 \mathrm{~min}$. Os valores obtidos referentes à expressão do mRNA de PDS foram normalizados pela expressão do mRNA de beta-actina (gene constitutivo), por 
PCR em Tempo Real. Os dados encontram-se representados como média \pm SEM. Foram realizados 3 experimentos. Nos estudos in vivo foram utilizados pelo menos 3 ratos por grupo e nos in vitro utilizamos $n=3 /$ grupo/experimento. ${ }^{* *} p<0,01 ;{ }^{* * * *} p<0,0001$ vs $C$. Análise de variância (ANOVA) de uma via seguida de pós-teste com Student-Newman-Keuls.

\subsection{Efeito da administração de Nal sobre a meia-vida do transcrito de pendrina}

Esse estudo teve o objetivo de investigar se a elevação do conteúdo de mRNA de pendrina em resposta ao tratamento com iodeto de sódio se devia a um aumento da estabilidade deste transcrito. A análise da curva obtida neste experimento mostrou que o tratamento com iodeto na dose de $10^{-3} \mathrm{M}$ não alterou a taxa de decaimento do mRNA de pendrina ao longo do tempo do estudo (30 min a 6 h) (Figura 7). $O$ gráfico demonstra que, após $6 \mathrm{~h}$, ambos os grupos (controle e tratados com $\mathrm{Nal}$ ) apresentaram uma redução de aproximadamente $20 \%$ do conteúdo total de mRNA de pendrina, em relação do tempo inicial (0h).

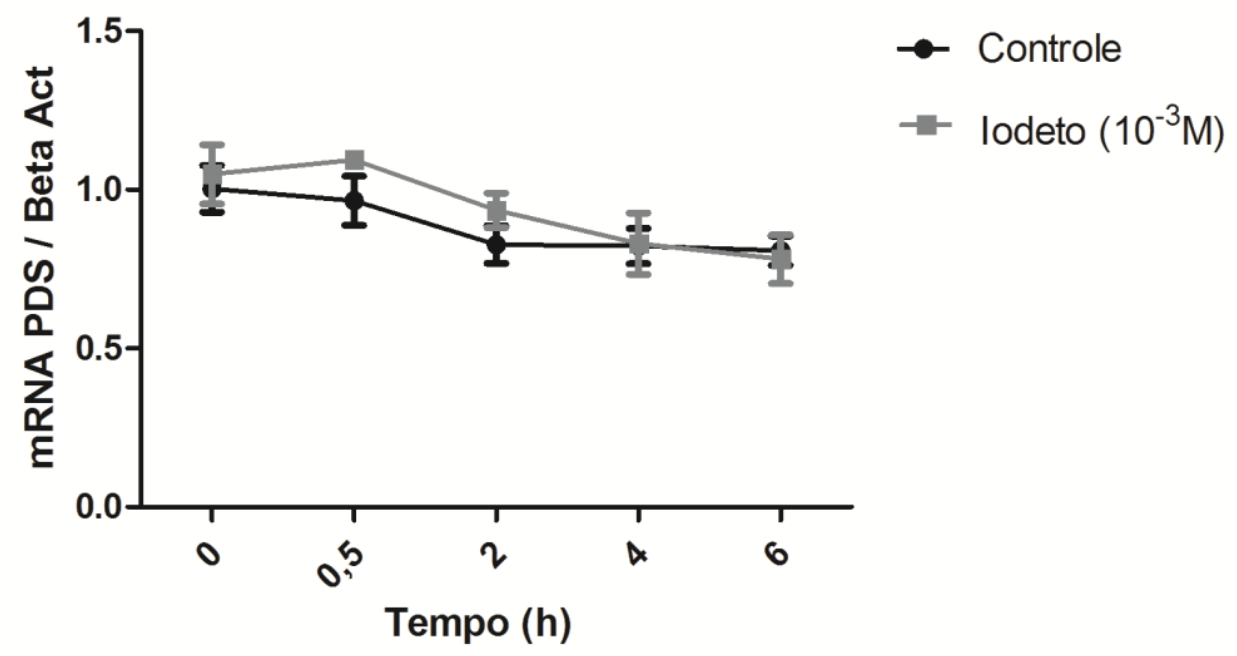

Figura 7 - Taxa de decaimento do mRNA de pendrina (PDS) frente ao excesso de iodeto $\left(10^{-3} \mathrm{M}\right)$. Curva de decaimento do mRNA de PDS de células PCCl3 tratadas (linha cinza) e não tratadas (linha preta) com excesso de iodeto, após tratamento prévio por $1 \mathrm{~h}$ com actinomicina $D ; n=6$ para ambos os grupos, em cada um dos períodos de tempo estudados. $P>0,05$. Análise de variância (ANOVA) de duas vias.

A ausência de alteração na taxa de decaimento do mRNA de pendrina após o tratamento com iodeto sugere que o aumento do conteúdo deste transcrito, observado na figura 4, seja resultado de uma ação transcricional desse oligoelemento, hipótese que foi analisada a seguir. 


\subsection{Efeito da administração de Nal sobre a expressão do mRNA de pendrina em} células $\mathrm{PCCl} 3$ submetidas ao bloqueio da transcrição gênica

A Figura 8 A mostra que o aumento do conteúdo de mRNA de pendrina observado em células $\mathrm{PCCl} 3$ tratadas com Nal por 30 min (Fig. 4) foi completamente abolido pela exposição prévia das células a actinomicina $D$ (droga que bloqueia a transcrição gênica). O bloqueio do aumento foi também observado num tempo mais longo (6 h) de tratamento com Nal, na presença de actinomicina D (Fig. 8 B) (CALILSILVEIRA et al., 2012).
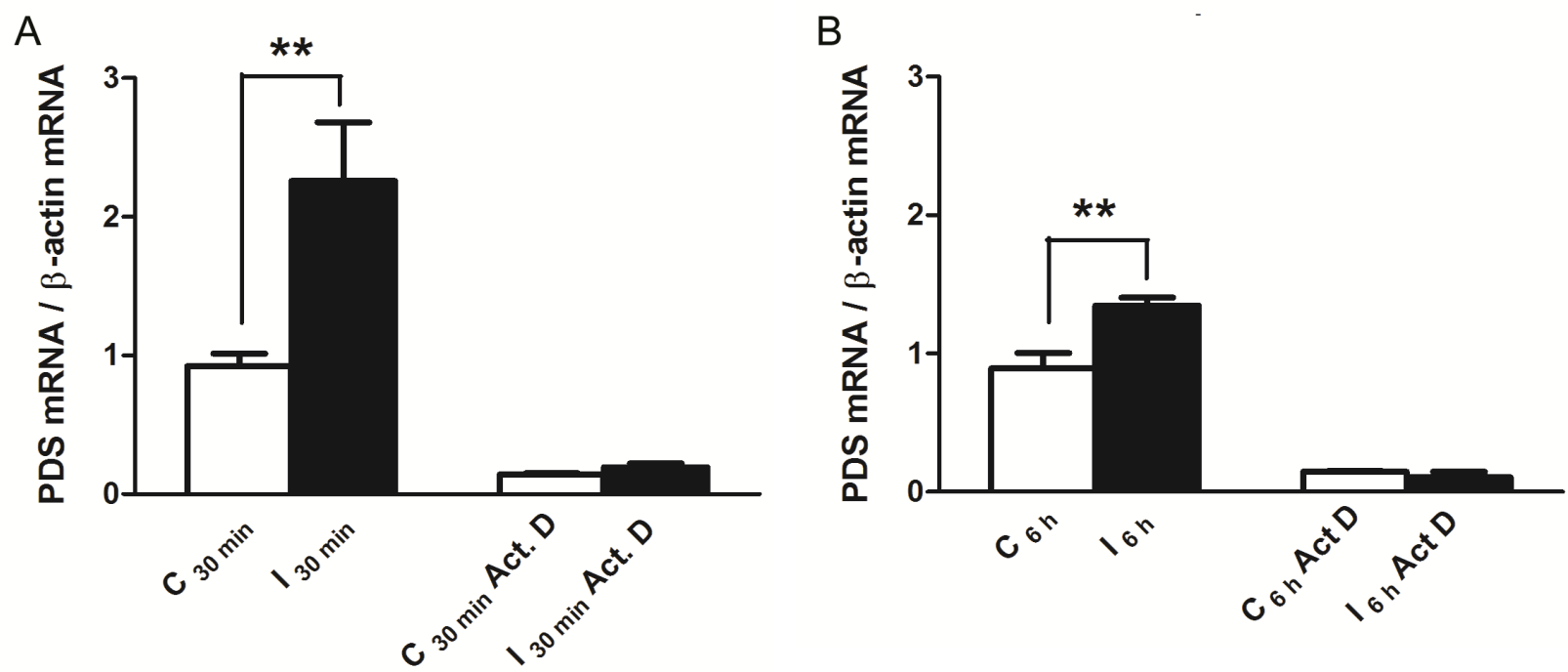

Figura 8 - Efeito do tratamento com Nal sobre o conteúdo de mRNA de pendrina (PDS) de células $\mathrm{PCCl} 3$ previamente tratadas com actinomicina $\mathrm{D}$. A figura 7A mostra experimentos realizados em células tratadas (I) ou não (C) com $\mathrm{Nal}$ por $30 \mathrm{~min}$, com ou sem administração prévia de actinomicina D (C 30 min, C 30 min Act. D, I 30 min and I 30 min Act. D), enquanto a figura 7B mostra experimentos similares feitos em células tratadas (I) ou não (C) com Nal por 6 h (C 6 h, C 6 h Act. D, I 6 h and I 6 h Act. D). Os valores obtidos referentes à expressão do mRNA de PDS foram normalizados pela expressão do mRNA de beta-actina (gene constitutivo), por PCR em Tempo Real. Os dados encontram-se representados como média \pm SEM. Foram realizados três experimentos com $n=3 /$ grupo/experimento ${ }^{* *} \mathrm{p}<0,01$ vs $C$. Análise de variância (ANOVA) de uma via seguida de pós-teste com Student-Newman-Keuls.

\subsection{Efeito da administração de $\mathrm{Nal}$ na expressão do $\mathrm{ClC}-5$ em células $\mathrm{PCCl} 3$}

Uma vez que o ClC-5 é apontado como um dos transportadores apicais de iodeto no tirócito, investigou-se se 0 tratamento com Nal também poderia regular a expressão do seu mRNA. A figura 9 mostra que o conteúdo de mRNA de CIC5 aumentou significativamente após 30 min da administração de Nal, comparado com o grupo controle. Não houve alteração significativa da expressão deste mRNA nos demais tempos estudados. 


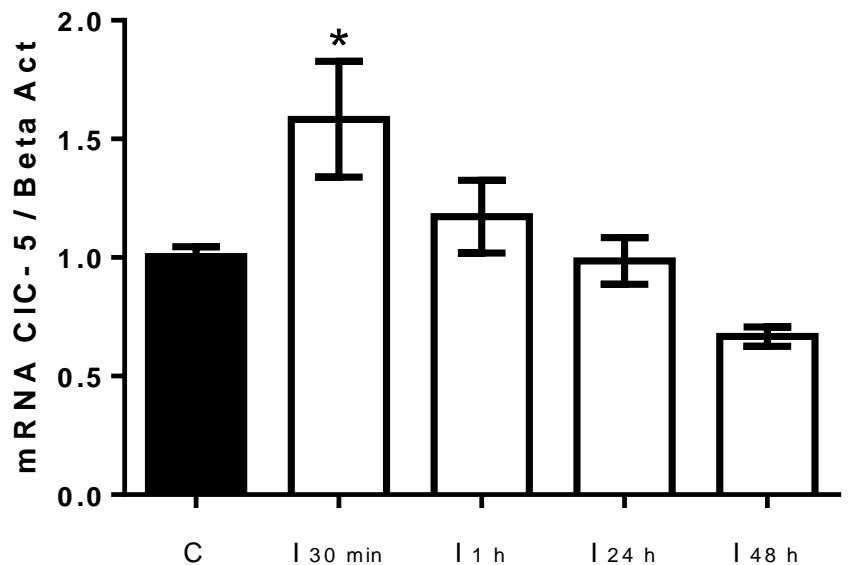

Figura 9 - Avaliação do conteúdo de mRNA do Canal de Cloreto 5 (CIC-5) de células PCCl3 tratadas ou não com excesso de $\mathrm{Nal}\left(10^{-3} \mathrm{M}\right)$. Os valores obtidos referentes à expressão do mRNA de CIC-5 foram normalizados pela expressão do mRNA de beta-actina (gene constitutivo), por PCR em Tempo Real. Os dados encontram-se representados como média

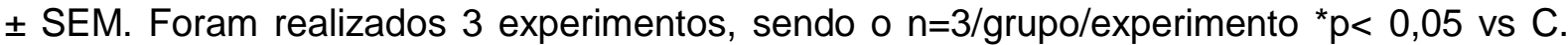
Análise de variância (ANOVA) de uma via seguida de pós-teste com Student-Newman-Keuls

\subsection{Avaliação da expressão do mRNA do fator transcricional tiroidiano TTF-1}

Visando compreender os mecanismos envolvidos no aumento da expressão do mRNA de Pendrina em resposta ao iodeto investigamos, inicialmente, se o tratamento com Nal teria algum efeito na expressão do mRNA do fator transcricional TTF-1. Observamos, tanto nos estudos in vivo quanto nos in vitro (Figuras $10 \mathrm{~A} \mathrm{e}$ $B)$, que frente ao excesso de iodeto não ocorreu alteração significativa na expressão desse mRNA.

A.

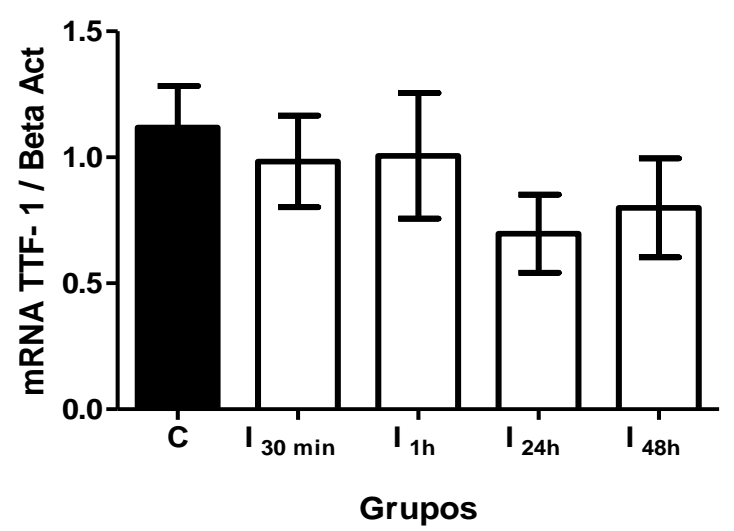

B.

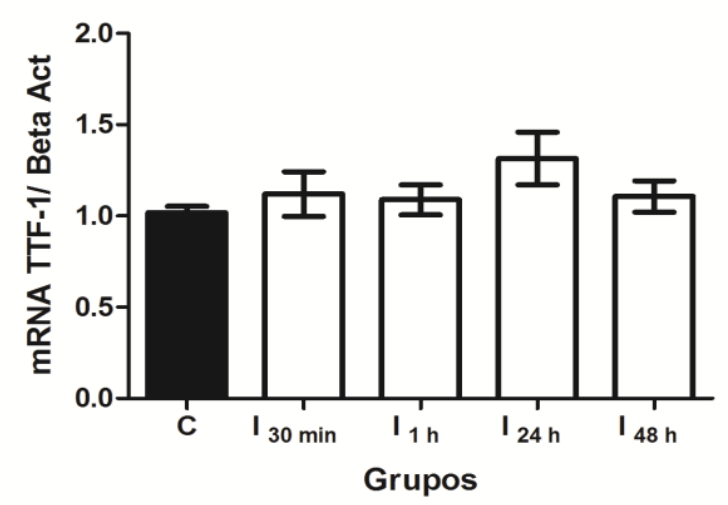

Figura 10 - Avaliação do conteúdo de mRNA de TTF1 em tiróide de ratos Wistar (A) e células PCCI3 (B) sob tratamento ou não com excesso de iodeto $\left(2 \mathrm{mg} \mathrm{Nal}\right.$ i.p./ $\left.10^{-3} \mathrm{M}\right)$ por $30 \mathrm{~min}, 1,24$ e 48h. Os valores obtidos referentes à expressão do mRNA de TTF-1 foram normalizados pela expressão do mRNA de beta-actina (gene constitutivo), por Real-Time PCR. Os dados encontram-se representados como média \pm SEM. Foram realizados 3 experimentos. Nos estudos in vivo foram utilizados pelo menos 3 ratos por grupo e nos in vitro utilizamos $n=3 / g r u p o / e x p e r i m e n t o . ~ p>0.05$ Análise de variância (ANOVA) de uma via, seguida de pós-teste com Student-Newman-Keuls. 


\subsection{Avaliação da localização subcelular do fator transcricional TTF-1, por imunofluorescência.}

O tratamento das células $\mathrm{PCCl} 3$ com iodeto gerou diferenças na localização subcelular do fator transcricional TTF-1, que se apresentou mais expresso na região nuclear dos tirócitos, e menos expresso na região citoplasmática, em todos os tempos estudados (Figura 11).

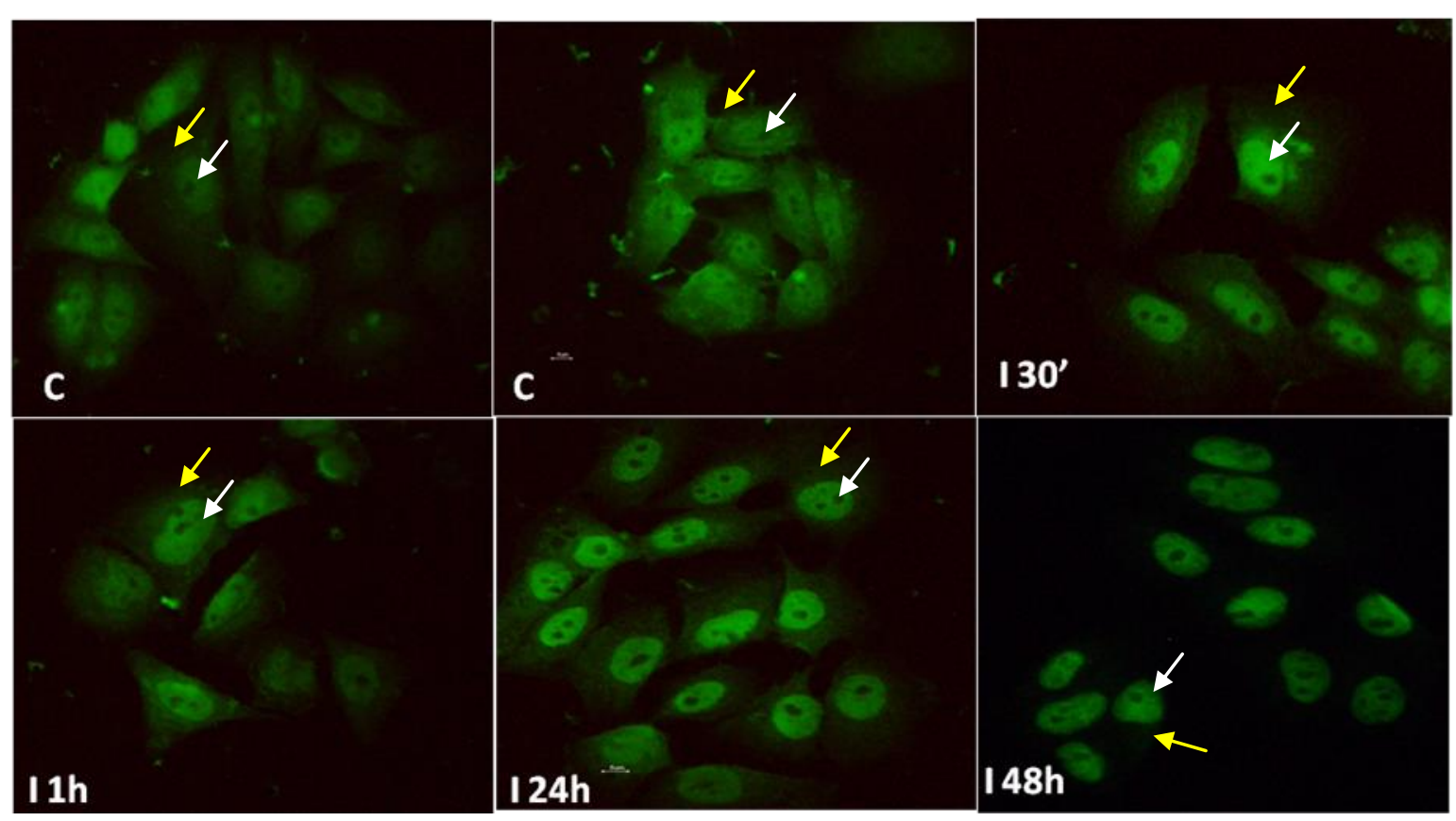

Figura 11 - Avaliação da expressão e localização subcelular de TTF-1 em células PCCl3, tratadas (I) ou não (C) com excesso de iodeto por $30 \mathrm{~min}, 1$, 24 e 48h, por ensaio de imunofluorescência. As setas brancas apontam para o núcleo das células, enquanto as setas amarelas apontam para o citoplasma. Imagens obtidas a partir da análise das lamínulas contendo células PCCl3 fixadas, em microscópio confocal (X400). A proteína TTF1 encontra-se marcada em verde (anti-rabbit-FITC, 1:100).

\subsection{Avaliação da localização subcelular do fator transcricional TTF-1, por western blotting}

A partir de ensaios de fracionamento de proteínas do núcleo e citoplasma, in vitro, foi possível observar uma tendência de aumento de TTF-1 na fração nuclear nos tempos mais curtos de tratamento (30 min, 1 e 24 horas). A fração citoplasmática do TTF-1 também apresentou tendência de aumento nesses tempos de tratamento. No entanto, houve considerável diferença entre as amostras (Figura $12 \mathrm{~A}$ e B). 


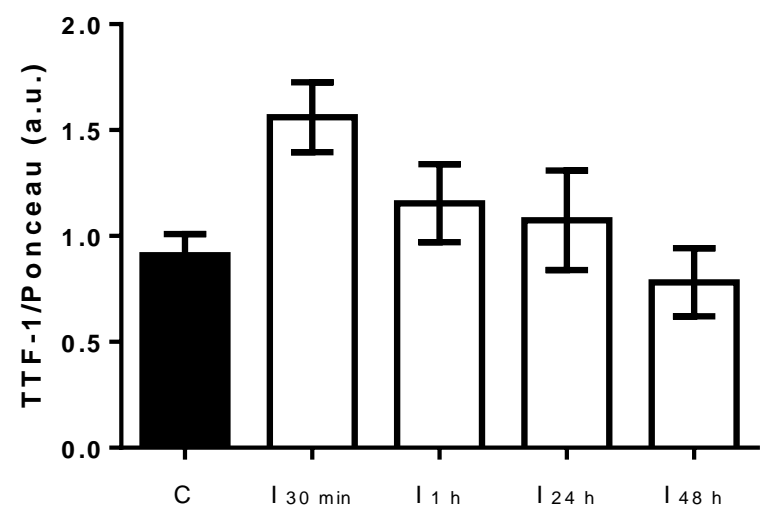

B

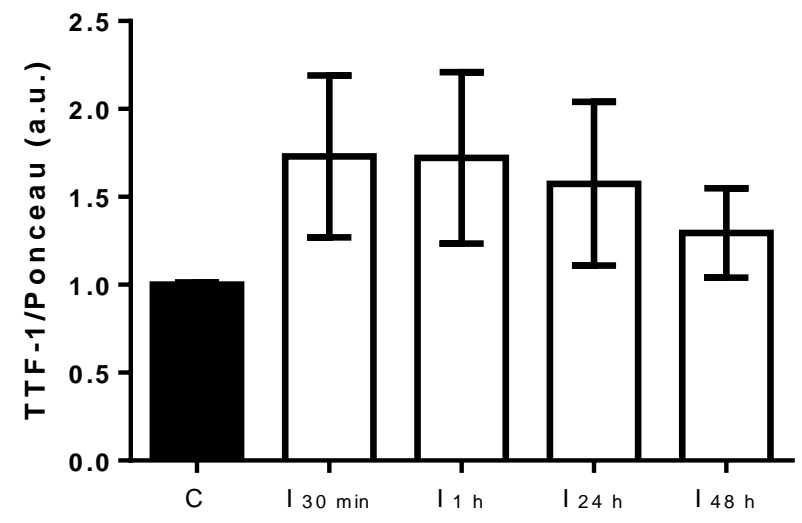

Figura 12 - Avaliação da localização nuclear (A) e citoplasmática (B) do fator transcricional TTF-1, de células PCCl3 submetidas ao tratamento com excesso de iodeto, por ensaios de fracionamento proteico, seguidos de western blotting. Os dados encontram-se representados como média \pm SEM. Foram realizados 3 experimentos com $n=3 / g r u p o / e x p e r i m e n t o$. $P>0.05$. Análise de variância (ANOVA) de uma via, seguida de pósteste com Student-Newman-Keuls.

\subsection{Efeito do tratamento com Nal sobre a atividade do promotor de PDS de rato}

Uma vez que os estudos com actinomicina $D$ sugeriram uma ação transcricional do iodeto no gene PDS, buscou-se avaliar se o tratamento com iodeto aumentaria a atividade do promotor desse gene. Conforme mostrado na figura 13, nossos estudos em células PCCI3 não indicaram um efeito do iodeto na atividade do promotor completo de pendrina de rato, contendo $3 \mathrm{~kb}$ de extensão, uma vez que a atividade da luciferase se manteve similar àquela do grupo controle.
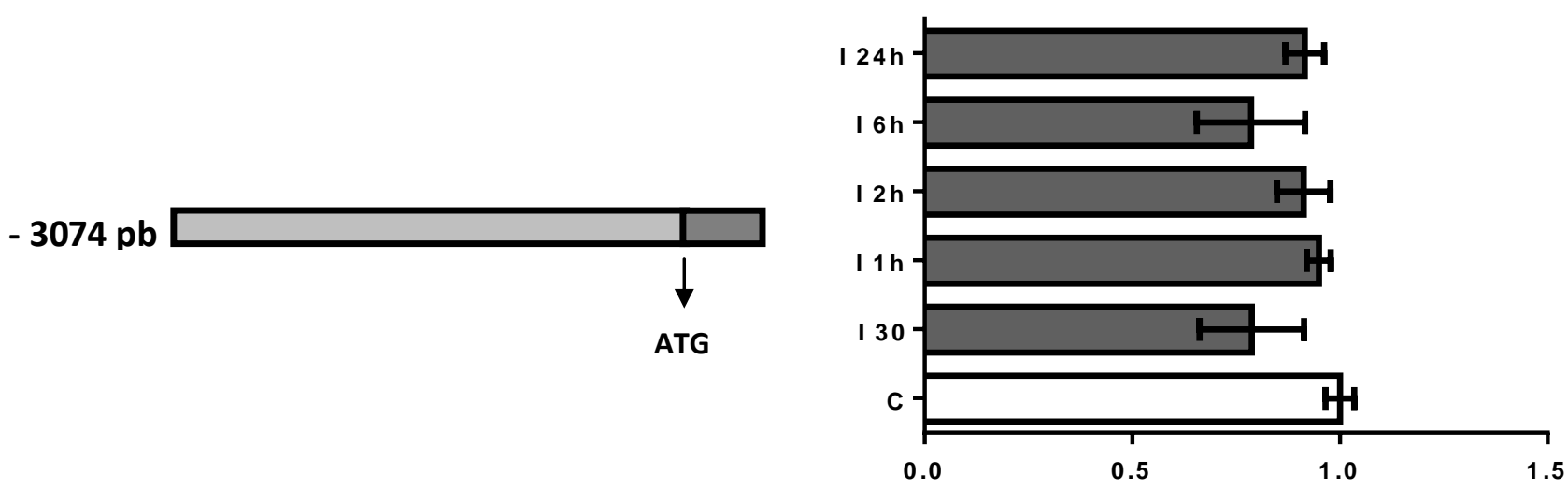

Atividade Relativa da Luciferase (Luc/P-gal) A.U.

Figura 13- Efeito do tratamento com Nal sobre a atividade do promotor completo de PDS de rato. Células $\mathrm{PCCl} 3$ foram transfectadas, de forma transiente, com plasmídeos contendo a região promotora de PDS upstream ao gene repórter da luciferase. O gráfico mostra a atividade transcricional do promotor em resposta ao tratamento com $\mathrm{Nal}$, por $30 \mathrm{~min}, 1,2,6$ e $24 \mathrm{~h}$. Os resultados são expressos como atividade relativa da luciferase, normalizada para a atividade relativa da $\beta$-galactosidase. Foram realizados 3 experimentos, com $n=3$ por grupo/ experimento. P>0.05. Análise de variância (ANOVA) de uma via, seguida de pósteste com Student-Newman-Keuls 


\subsection{Efeito do tratamento com Nal sobre a atividade do promotor de PDS de humano}

De forma semelhante ao observado nos estudos referentes ao efeito do iodeto na atividade do promotor de pendrina de rato, não foi observado alteração na atividade de nenhum dos dois fragmentos do promotor de PDS humano estudados (Figura 14).

$-2052$
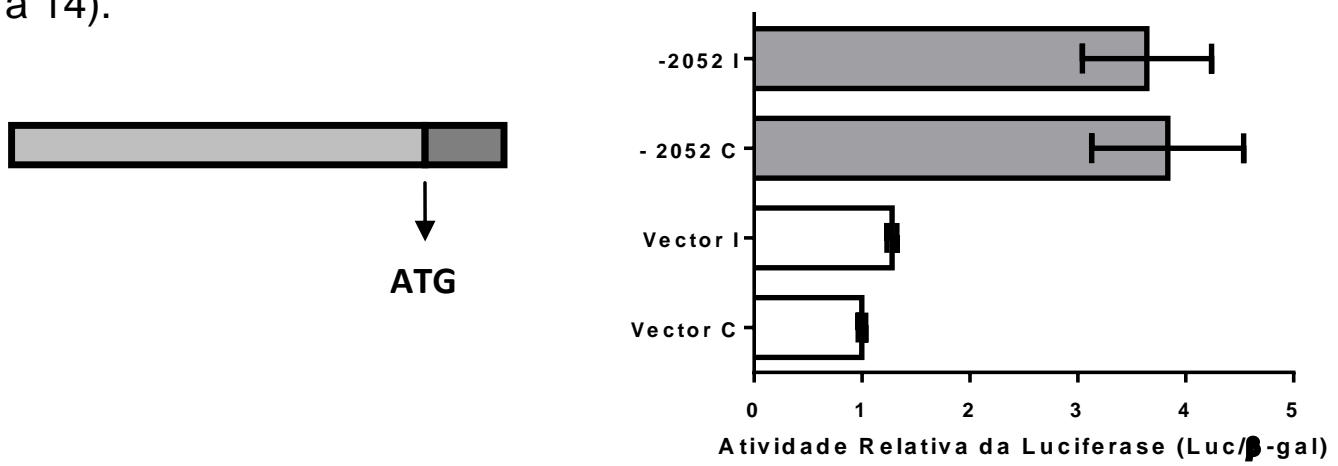

A.U.

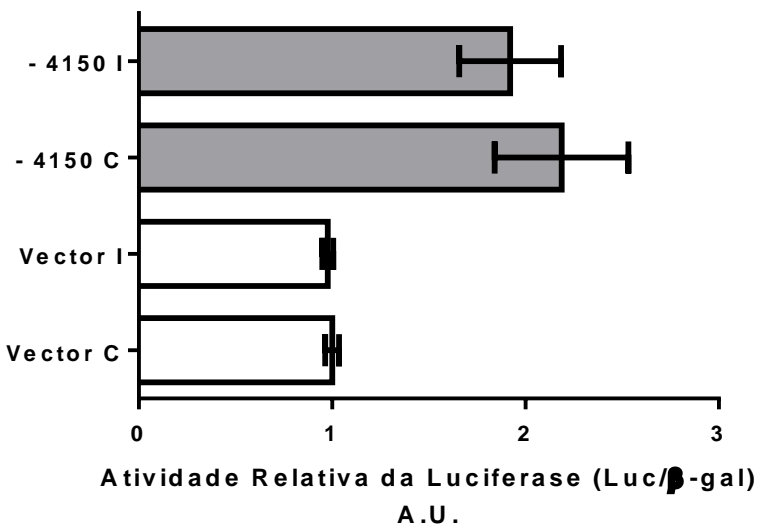

Figura 14- Efeito do tratamento com Nal sobre a atividade de 2 fragmentos do promotor de PDS humano contendo 2,0 kb (-2052) e 4,1 kb (-4150). Células PCCl3 foram transfectadas, de forma transiente, com plasmídeos vazios (Vector) ou contendo uma das regiões promotoras de PDS upstream ao gene repórter da luciferase. O gráfico mostra a atividade transcricional do promotor em resposta ao tratamento com Nal, por $1 \mathrm{~h}$. Os resultados são expressos como atividade relativa da luciferase, normalizada para a atividade relativa da Renilla. Foram realizados 3 experimentos, com $n=3$ por grupo/experimento. $P>0.05$. Análise de variância (ANOVA) de uma via, seguida de pós-teste com Student-Newman-Keuls

Interessante notar a possível existência de um elemento regulatório negativo (ERN) entre as regiões -2052 e -4150 do promotor de hPDS, uma vez que a deleção desse fragmento acarreta em maior atividade da luciferase (Figura 15). 


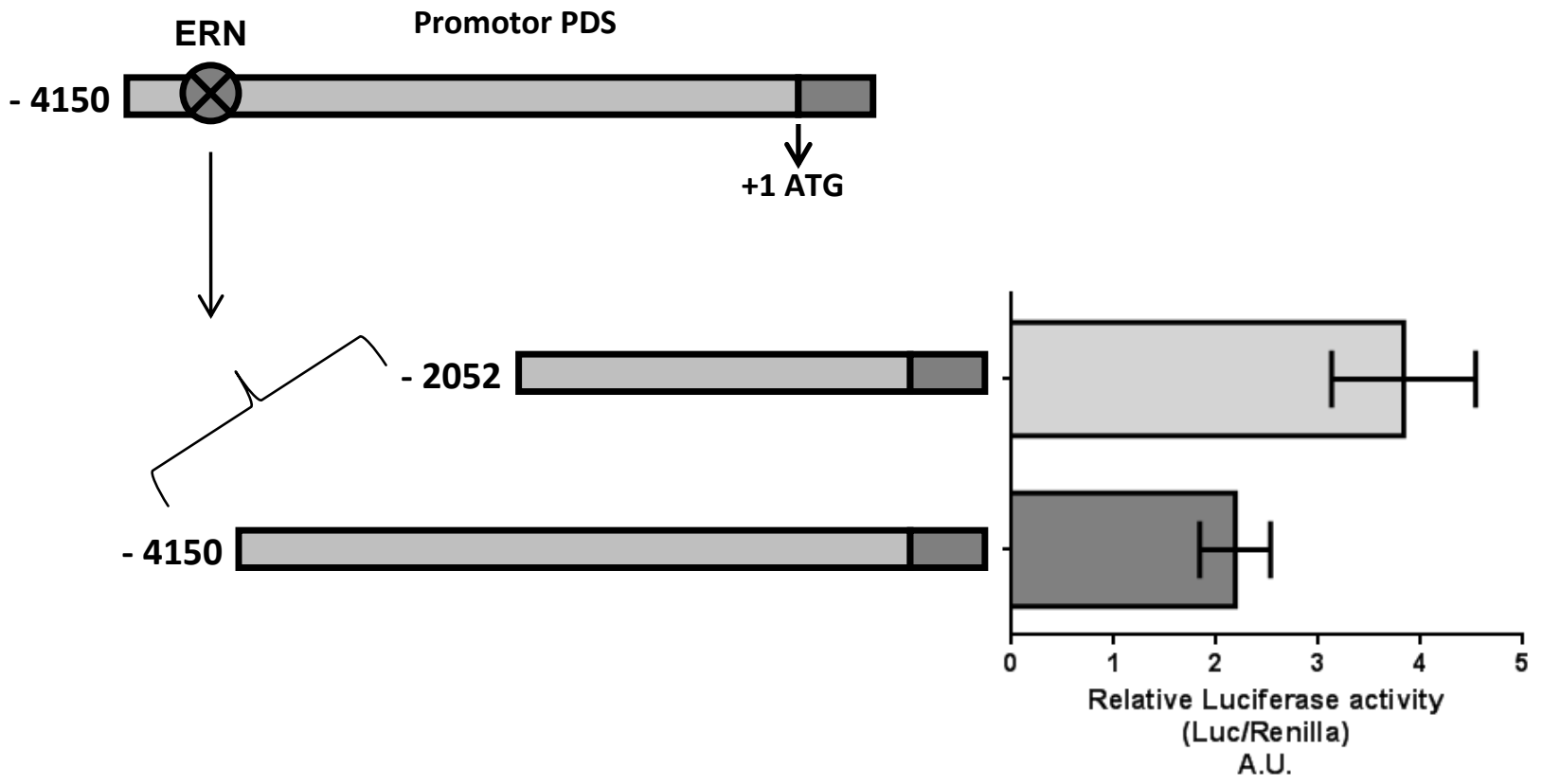

Figura 15 - Efeito da deleção de parte do promotor de PDS humano sobre a atividade da luciferase. Células PCCI3 foram transfectadas, de forma transiente, com plasmídeos contendo distintos fragmentos (-4150 e -2052) da região promotora de PDS a montante ao gene repórter da luciferase. O gráfico mostra a atividade transcricional do promotor. Os resultados são expressos como atividade relativa da luciferase, normalizada para a atividade relativa da Renilla. Foram realizados 3 experimentos, com $n=3$ por grupo/experimento. $p=$ 0,052, Análise de variância (ANOVA) de uma via, seguida de pós-teste com StudentNewman-Keuls.

\subsection{Efeito do tratamento com Nal sobre a ligação do fator transcricional TTF-1 à região promotora de PDS - ChIP assay}

Devido ao fato da imunofluorescência sugerir que o tratamento com $\mathrm{Nal}$ aumenta o conteúdo de TTF-1 no núcleo de células PCCl3, buscou-se investigar através da imunoprecipitação da cromatina (ChiP assay) se esse fator transcricional poderia ligar-se em regiões específicas próximas ao gene PDS. Com o PCR feito com amostras geradas de ensaios de ChiP assay, em que utilizou-se o anticorpo TTF-1, observou-se que o tratamento das células $\mathrm{PCCl} 3$ com excesso de iodeto por 30 min acarretou em ligação do TTF-1 numa região $15 \mathrm{~kb}$ a montante ao promotor de PDS (Figura 16). Esse dado vai de encontro aos experimentos observados no estudo do promotor deste gene (Figuras 13 e 14), que não apresentaram alteração 
de sua atividade, mas que também não possuíam em sua sequencia esta região a montante.

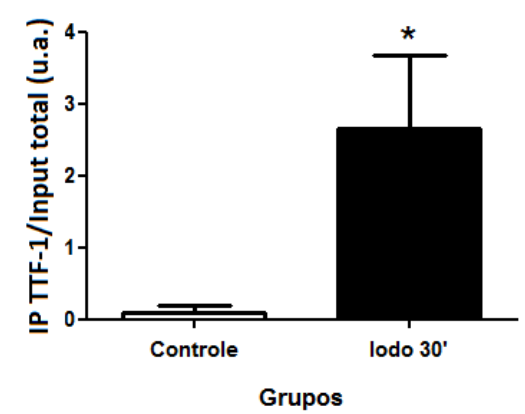

Figura 16 - Efeito do excesso de iodeto sobre a associação entre o fator transcricional TTF-1 e região a montante ao gene da pendrina. Foi feito ensaio de imunoprecipitação da cromatina utilizando-se o anticorpo anti-TTF-1 (Santa Cruz), seguido de PCR com primers da região em que houve suposta ligação de TTF-1. Foi realizado um experimento com $n=6$ por grupo. * $p=0,013$ vs $C$. Teste t de Student não pareado.

As reações de PCR em que foram testadas as outras sequencias de primers (PDS1 e PDS2) não apresentaram amplificação, sugerindo que não houve ligação de TTF-1 nessas regiões do gene, e consequentemente não houve precipitação das mesmas.

\subsection{Investigação da região $15 \mathrm{~kb}$ a montante ao promotor de PDS em células $\mathrm{PCCl} 3$}

Buscamos avaliar se a região sugerida pelo ChiP assay como sendo responsiva ao TTF-1 seria capaz de ativar a transcrição do gene da luciferase em células PCCl3 transfectadas com plasmídeo pGL3 Básico contendo ou não a região $15 \mathrm{~kb}$ de interesse, à montante do gene da luciferase, na presença ou não de excesso de iodo. A figura 17 mostra que a inserção desse fragmento no plasmídeo não acarretou em ativação do gene da luciferase na presença ou ausência de iodo.

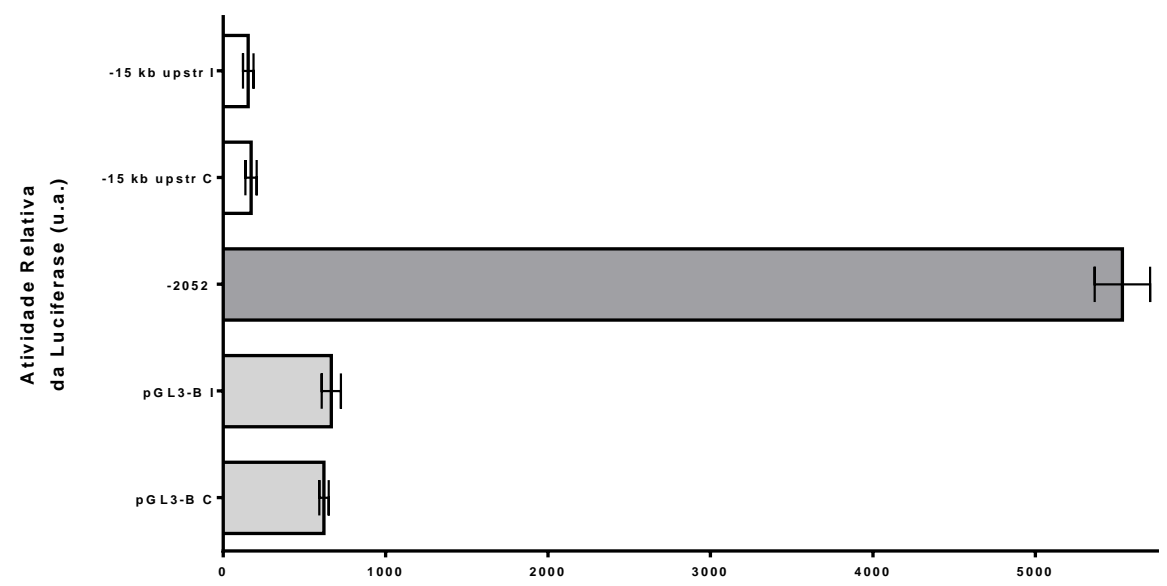

Figura 17- Avaliação do efeito do iodo na atividade da luciferase em células PCCl3 transfectadas com plasmídeo pGL3 Básico vazio (barras cinzas: pGL3-B I e pGL3-B C; 
controle negativo) ou contendo o fragmento correspondente a região $15 \mathrm{~kb}$ a montante do gene da luciferase (barras brancas: $-15 \mathrm{~kb}$ upstr I e -15kb upstr C), onde I representa células tratadas com iodo e $\mathrm{C}$ as controle. A barra mais escura ilustra a atividade da luciferase em células PCCl3 transfectadas com um trecho do promotor de PDS humano (-2052). Os resultados são expressos como atividade relativa da luciferase, normalizada para a atividade relativa da Renilla. Foram realizados 2 experimentos, com $n=3$ por grupo Análise de variância (ANOVA) de uma via, seguida de pós-teste com Student-Newman-Keuls.

\subsection{Avaliação do conteúdo da proteína PDS frente ao excesso de iodeto - Western Blotting}

A fim de investigar se o aumento do conteúdo de mRNA de pendrina frente ao excesso de iodo estaria acarretando em maior conteúdo protéico, realizamos estudos in vivo e in vitro, em que a expressão de pendrina foi avaliada por western blotting. Diferentemente do que ocorreu com a expressão do mRNA, o conteúdo total da proteína não apresentou diferença significativa em relação ao controle nos períodos mais curtos de tratamento com iodo, tanto no modelo animal quanto no in vitro (figuras 17 e 18). Todavia, no estudo in vivo houve aumento significativo da expressão protéica de pendrina no tempo mais longo de exposição ao iodo estudado (48 h) (Figura 17), enquanto que nas células PCCl3, o tratamento com 10-3 M de iodeto acarretou em aumento significativo da expressão protéica de pendrina em períodos mais curtos de exposição ao iodo (24 h) (Figura 18), dado que sugere que o efeito do iodeto nas células acontece mais rapidamente, quando comparado ao modelo in vivo.

\section{PDS}

\section{GAPDH}

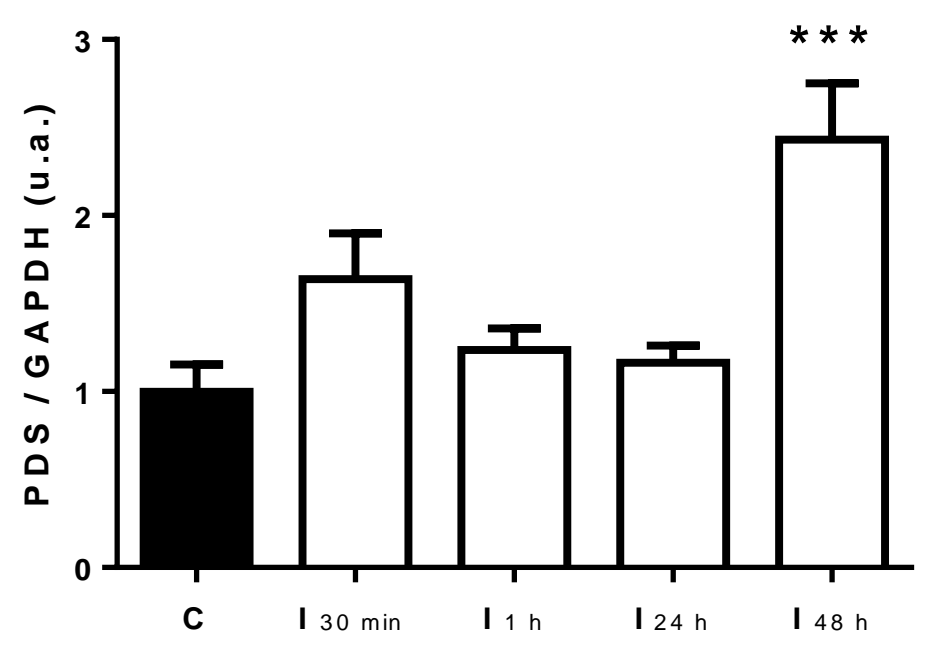


Figura 18 - Avaliação da expressão de Pendrina (PDS) em tiroide de ratos submetidos (I) ou não (C) ao excesso de iodeto (2mg/rato), por $30 \mathrm{~min}, 1,24$ e $48 \mathrm{~h}$. Acima, temos as imagens representativas do conteúdo de pendrina obtidas em 1 experimento (5 animais/grupo). Abaixo, a representação gráfica dos resultados obtidos com a análise densitométrica dos blots indicativas do conteúdo total de PDS nos grupos $\mathrm{C}$ e lodo (30 min - $48 \mathrm{~h}$ ). Os dados encontram-se representados como média \pm SEM. ${ }^{\star \star *} p<0,001$ vs $C$. Análise de variância (ANOVA) de uma via, seguida de pós-teste com Student-Newman-Keuls.

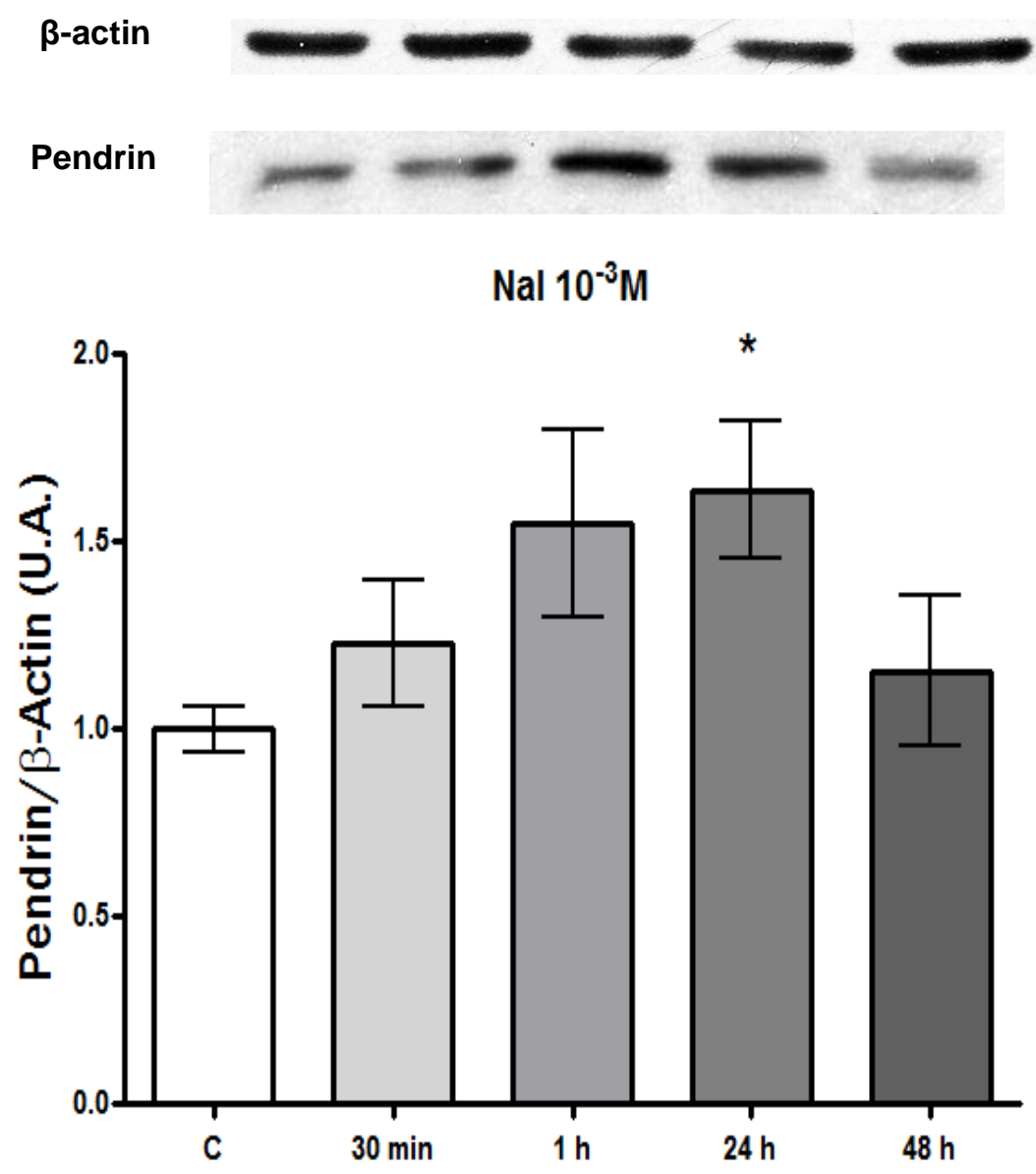

Figura 19 - Figura 19 - Avaliação da expressão de Pendrina (PDS) em células PCCl3 tratadas (I) ou não (C) com $10^{-3^{3}} \mathrm{M}$ de iodeto por $30 \mathrm{~min}, 1,24$ e $48 \mathrm{~h}$. Acima, temos as imagens representativas do conteúdo de pendrina obtidas em 1 experimento, num total de 6 experimentos, e abaixo, a representação gráfica dos resultados obtidos com a análise densitométrica dos blots indicativas do conteúdo total de PDS nos grupos $\mathrm{C}$ e lodo (30 min $48 \mathrm{~h})$. ( $n=6)$. Os dados encontram-se representados como média \pm SEM. $p<0,05$ vs $C$. Análise de variância (ANOVA) de uma via, seguida de pós-teste com Student-NewmanKeuls.

Doses menores de iodeto foram testadas, mas nenhuma foi capaz de acarretar em alteração da expressão de pendrina (Figura 20). 
A
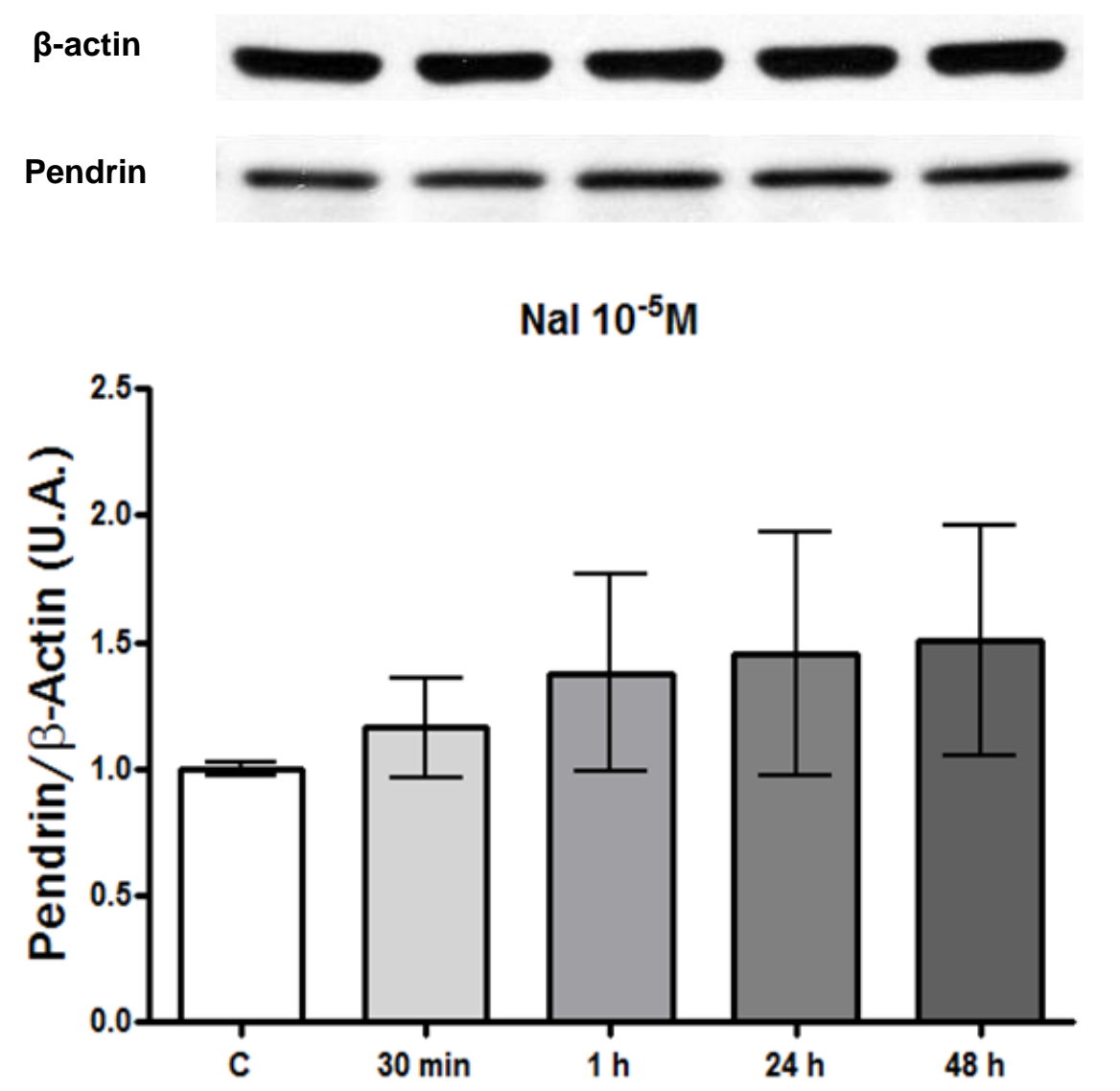

B
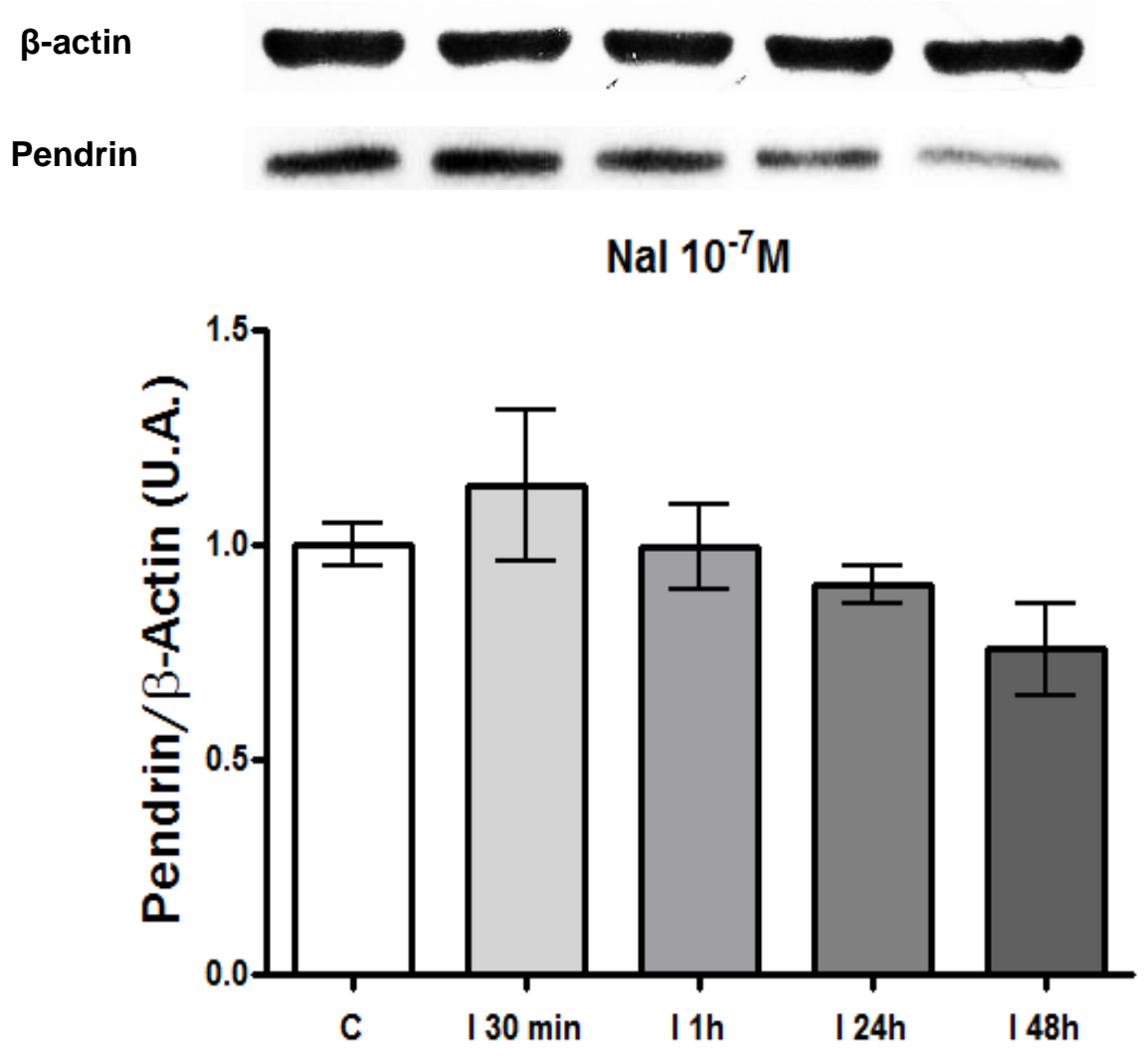
C

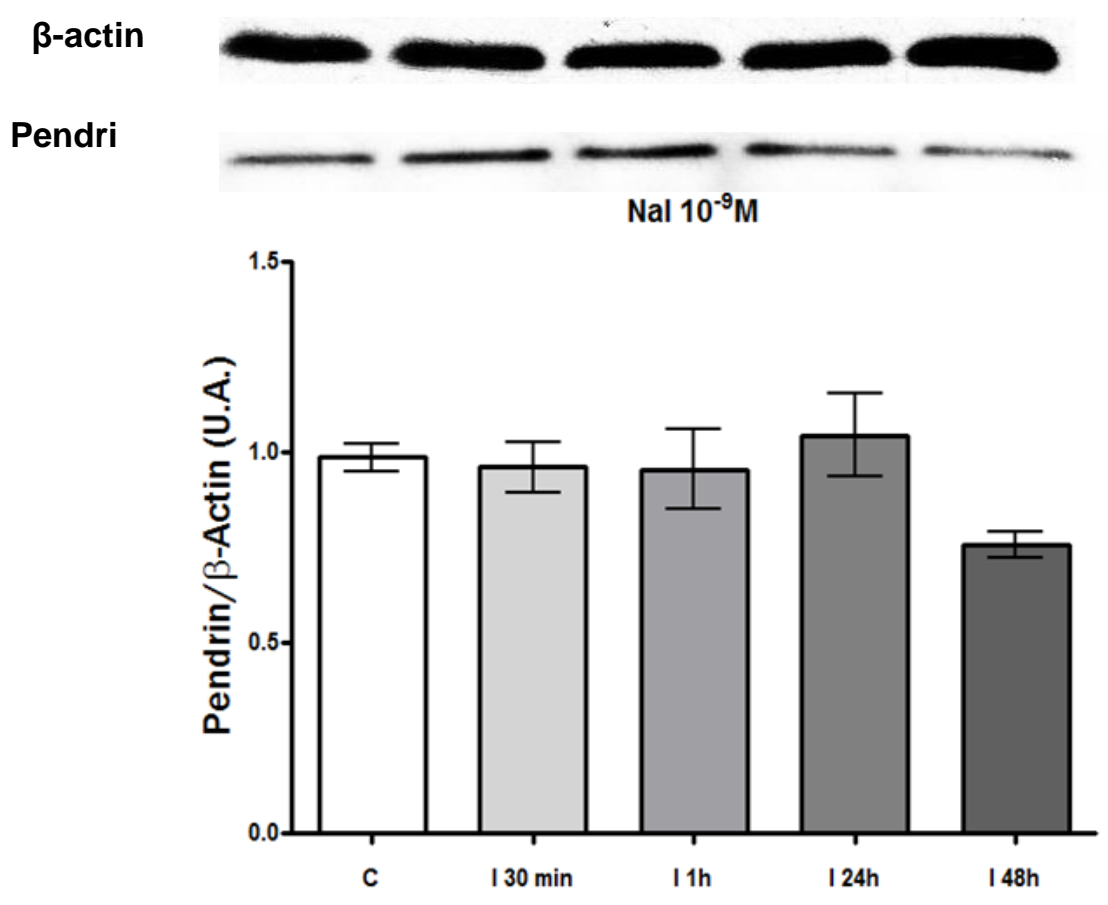

Figura 20 - Avaliação da expressão de Pendrina (PDS) em células PCCl3 tratadas com as doses $10^{-5}, 10^{-7}$ e $10^{-9} \mathrm{M}$ de $\mathrm{Nal}$ (A, B e C respectivamente), por $30 \mathrm{~min}, 1,24$ e 48 horas (I $30 \mathrm{~min}, \mathrm{I} 1 \mathrm{~h}, \mathrm{I} 24 \mathrm{~h}$ e I 48h). Acima, temos as imagens representativas do conteúdo de pendrina obtidas em 1 experimento, num total de 6 experimentos, e abaixo, a representação gráfica dos resultados obtidos com a análise densitométrica dos blots indicativas do conteúdo total de PDS nos grupos $C$ e lodo (30 min - 48 h). (n=6). Os dados encontram-se representados como média \pm SEM. $p>0,05$ vs $C$. Análise de variância (ANOVA) de uma via, seguida de pós-teste com Student-Newman-Keuls.

\subsection{Avaliação da localização subcelular da proteína Pendrina - Imunofluorescência.}

Buscando avaliar se o tratamento com iodeto alteraria a localização de pendrina no tirócito, avaliamos a sua distribuição nas células PCCl3, após 2, 12, 24 e 48h do tratamento, por imunofluorescência (IF). Não observamos diferenças na localização da proteína nas células tratadas com $\mathrm{Nal}$ por $2 \mathrm{~h}$ em relação ao grupo controle (lodo $2 \mathrm{~h}$, figura 20). Porém, quando o tratamento com $\mathrm{Nal}$ foi feito por tempos mais longos (12, 24 e 48h), observa-se uma marcação de pendrina mais forte e dispersa na periferia das células. 


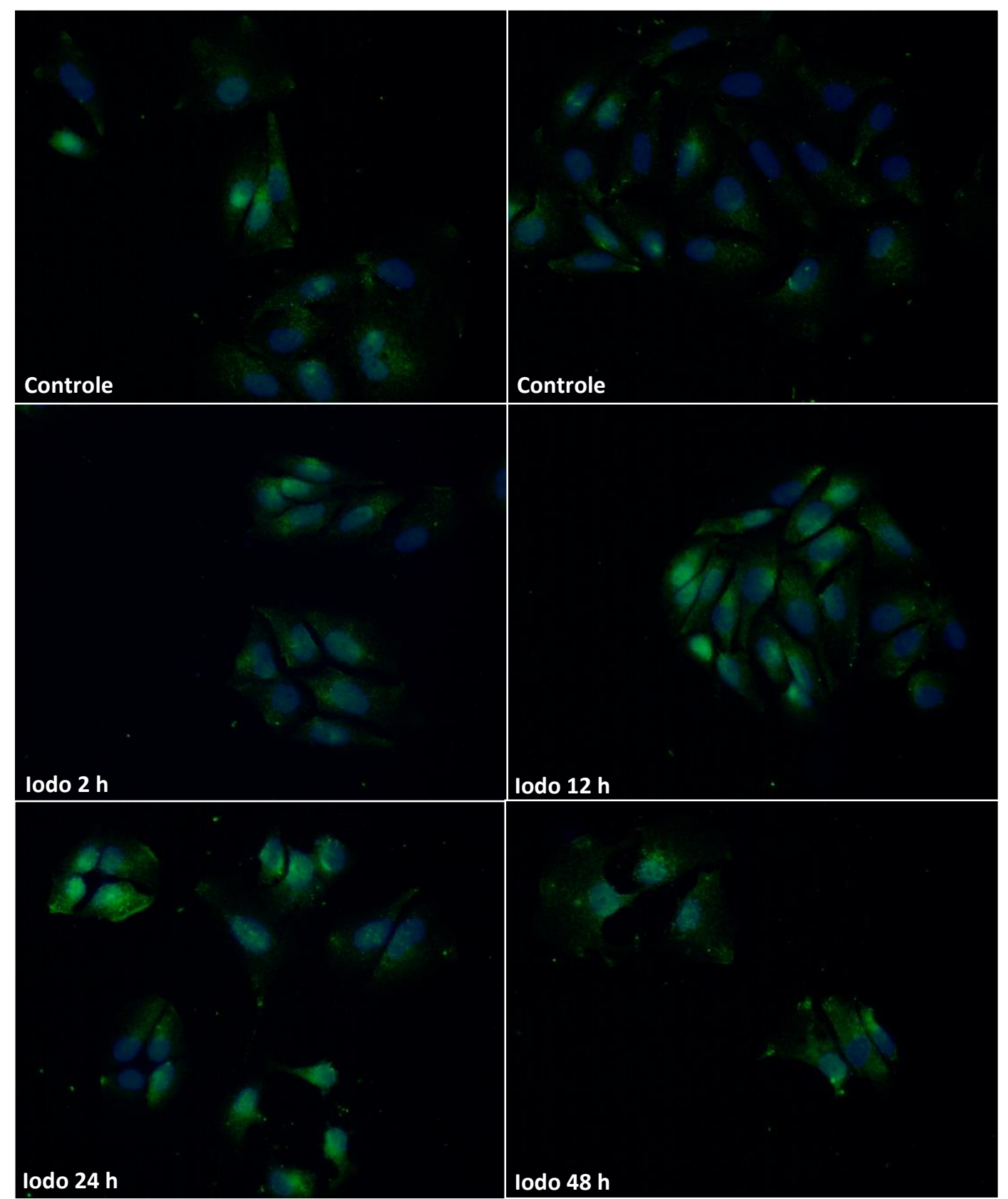

Figura 21 - Imagem das células PCCI3 (controle e tratadas com Nal - lodo 2, 12, 24 e 48 horas) apresentando, em verde, a marcação para pendrina, por imunofluorescência. A coloração verde se deve à marcação do anticorpo secundário FITC (isotiocianato de fluoresceína) ligado ao anticorpo de pendrina. Em azul, observa-se o núcleo das células corado com o marcador específico DAPI (4',6-diamidino-2-phenylindole). Aumento de 400x.

\subsection{Avaliação da taxa de efluxo de iodeto em células $\mathrm{PCCl} 3$ tradas com Nal}

Buscamos investigar em células PCCl3 submetidas a excesso de iodeto por 1, 2, 4 e $6 \mathrm{~h}$, se esse oligoelemento seria capaz de regular o seu próprio efluxo do tirócito. A figura 22 mostra a taxa de efluxo do $\mathrm{I}^{125}$ em cada um dos 3 pontos em que 
o meio de cultura foi coletado e a radiação medida, como descrito anteriormente. Nota-se que o tratamento das células com $10^{-3} \mathrm{M}$ de Nal por 1, 2, 4 e 6 horas não acarretou em mudança na taxa de efluxo do $\mathrm{I}^{125}$.

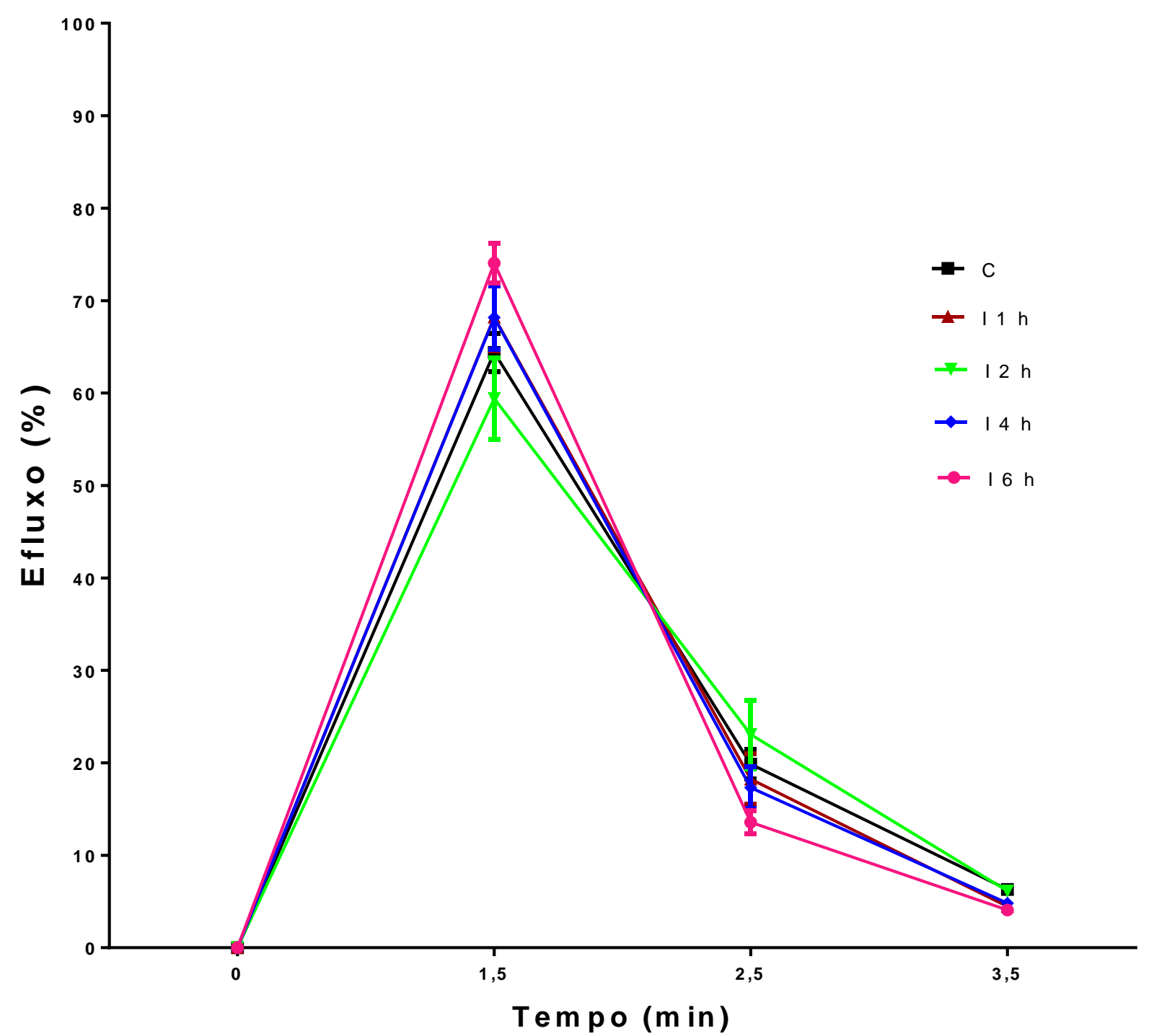

Figura 22- Avaliação da taxa de efluxo de $\mathrm{I}^{125}$ de células PCCI3 tratadas ou não com $10^{-3} \mathrm{M}$ de iodeto por 1, 2, 4 e 6 horas. Meio de cultura fresco foi adicionado e coletado 3 vezes (T1, T2, T3) ao longo de 3,5 min, tempo que corresponde a duração do ensaio, para medição da radiação emitida pelo $1^{125}$. Foram realizados 3 experimentos, com $n=3$ por grupo. Os traçados nas cores marrom(?), verde, azul e rosa representam a taxa de efluxo de de $\mathrm{I}^{125}$ das células tratadas por 1, 2, 4 e $6 \mathrm{~h}$ com excesso de iodo, respectivamente. $O$ traçado na cor negra representa o grupo controle (C). Os dados encontram-se representados como média \pm SEM. $p>0.05$ vs $C$. Análise de variância (ANOVA) de duas vias.

O próximo passo foi fazer a mesma análise em células tratadas com $10^{-3} \mathrm{M}$ de iodeto por tempos mais longos - 12, 24, e 48 horas (Figura 23). 


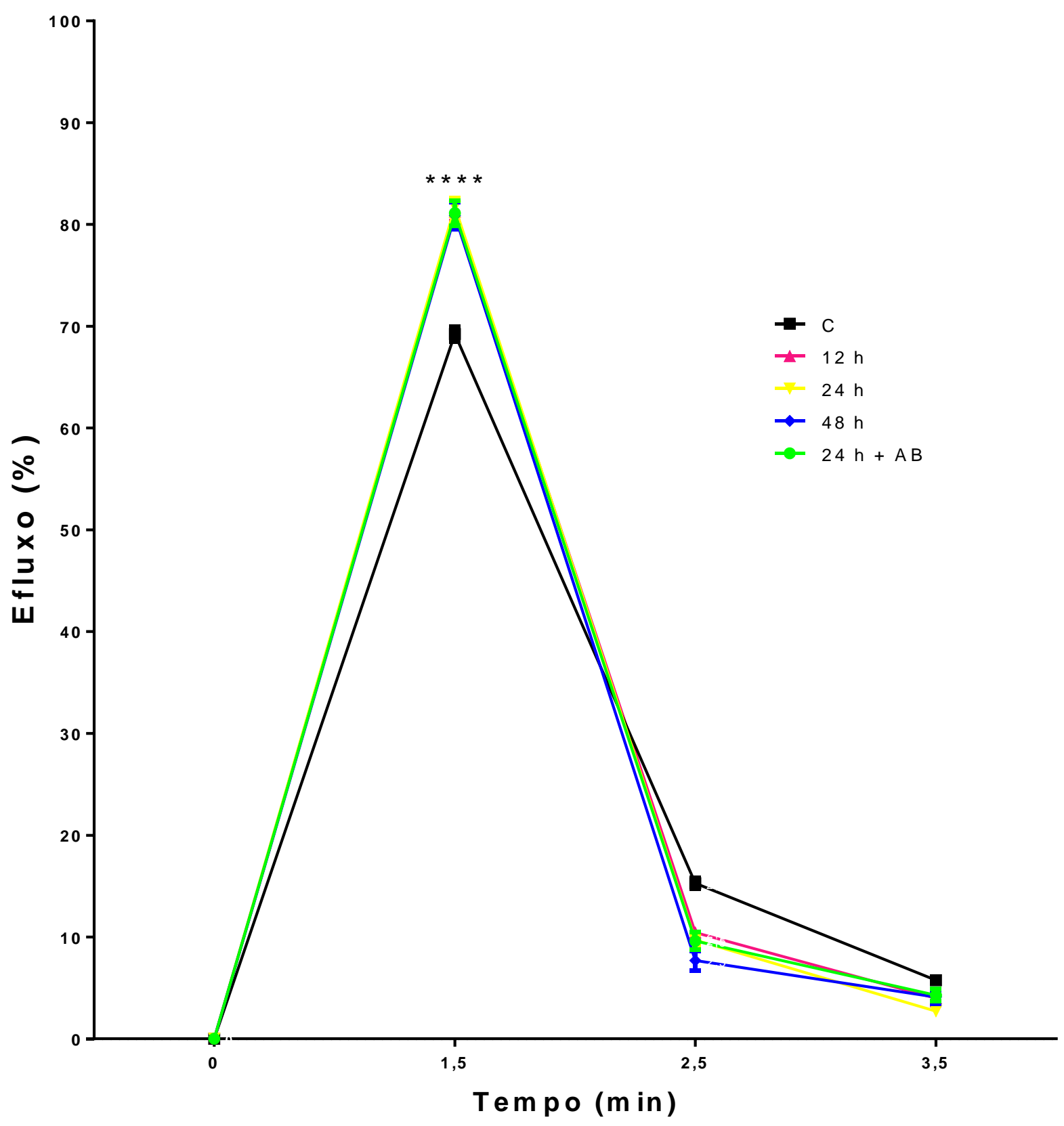

Figura 23- Avaliação da taxa de efluxo de $\mathrm{I}^{125}$ de células PCCI3 tratadas ou não com $10^{-3} \mathrm{M}$ de iodeto por 12, 24 e 48 horas. Meio de cultura fresco foi adicionado e coletado 3 vezes (T1, T2, T3), ao longo de 3,5 min, tempo que corresponde a duração do ensaio, para medição da radiação emitida pelo $\mathrm{I}^{125}$. Foram realizados 3 experimentos, com $\mathrm{n}=3$ por grupo. Os traçados nas cores rosa, amarela e azul representam a taxa de efluxo de de $1^{125}$ das células tratadas por 12, 24 e 48h com excesso de iodo, respectivamente. O traçado na cor negra representa o grupo controle $(C)$. Os dados encontram-se representados como média \pm SEM. ${ }^{* * *} p<0.0001$ vs $C$. Análise de variância (ANOVA) de duas vias.

Pode-se notar em ambas as figuras 22 e 23 que a maior parte do $1^{125}$ deixa a célula no primeiro tempo de coleta, T1 (1,5 minutos após adição do meio). Isso era esperado, uma vez que a diferença da concentração dentro e fora das células era bastante alta. No entanto, as células tratadas por períodos longos com Nal (figura 
23) apresentaram a taxa de efluxo no tempo $\mathrm{T} 1$ aproximadamente $15 \%$ maior, quando comparado ao Controle, que recebeu $10^{-3} \mathrm{M}$ de Nal por $30 \mathrm{~min}$.

A figura 24 compara apenas o tempo de coleta $\mathrm{T} 1$ dos grupos tratados por longos períodos com $\mathrm{Nal}$.

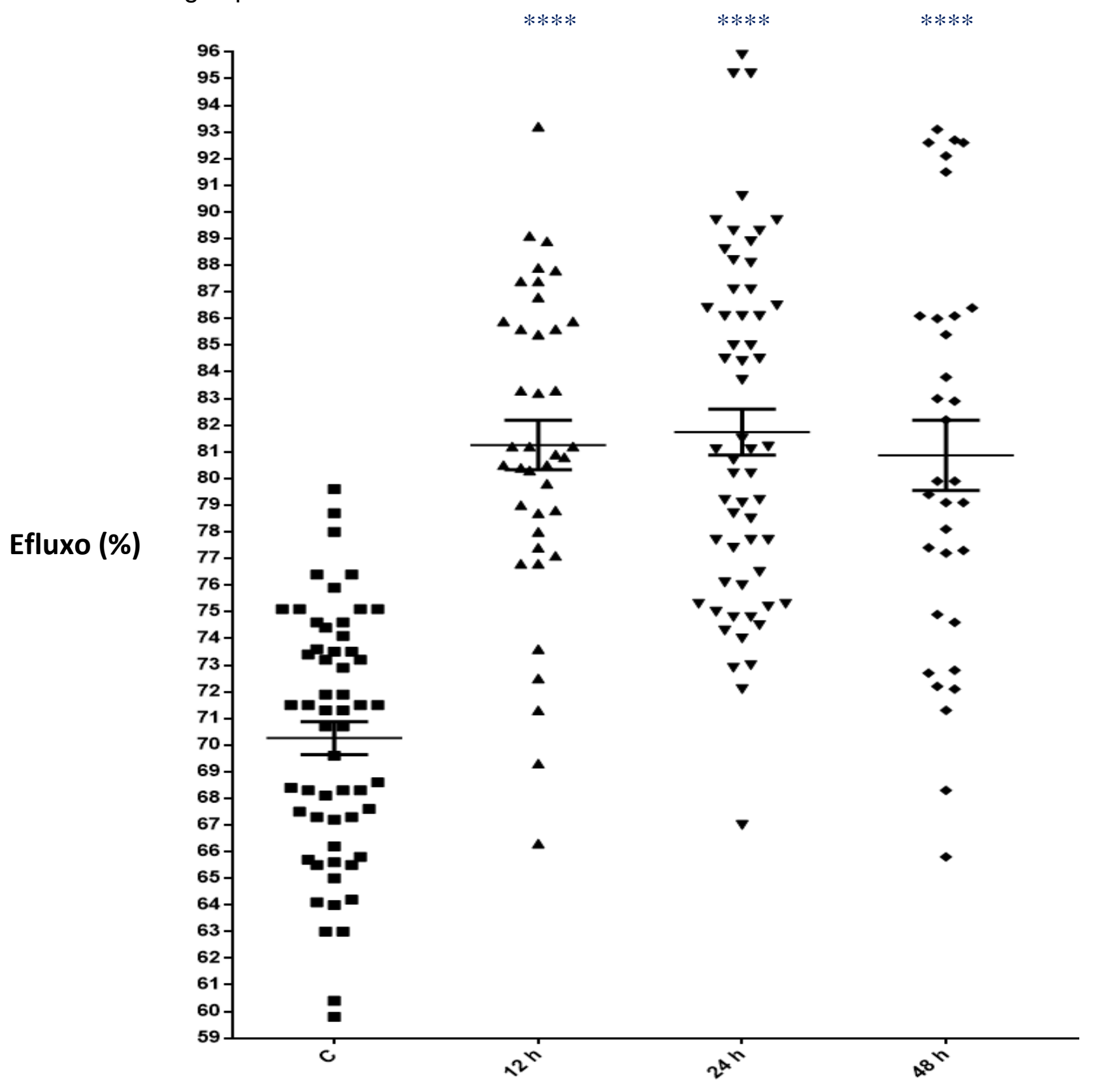

Figura 24 - Avaliação da taxa de efluxo de ${ }^{125}$ de células PCCl3 tratadas ou não com $10^{-3} \mathrm{M}$ de de Nal por 12, 24 e 48 horas. Meio de cultura fresco foi adicionado e coletado após 1,5 min para medição da radiação emitida pelo $I^{125}$. Foram realizados 3 experimentos, com $n=3$ por grupo. Análise de variância (ANOVA) de uma via C, Controle. Means $\pm \mathrm{SEM}$; ${ }^{* * * *} \mathrm{p}<$ 0.0001 vs $C$.

A figura 25 mostra que, apesar da maior taxa de efluxo nas células tratadas por longos períodos de tempo, a quantidade total captada de iodeto foi 
expressivamente menor. Isso é consistente com o fato de que NIS é altamente inibida pelo tratamento com $\mathrm{Nal}$, inibição essa que se mostrou ser tempodependente (Figura 25). Esse dado reforça a necessidade de expor a taxa de efluxo em porcentagem quando realizados experimentos em que há tratamento com iodeto.

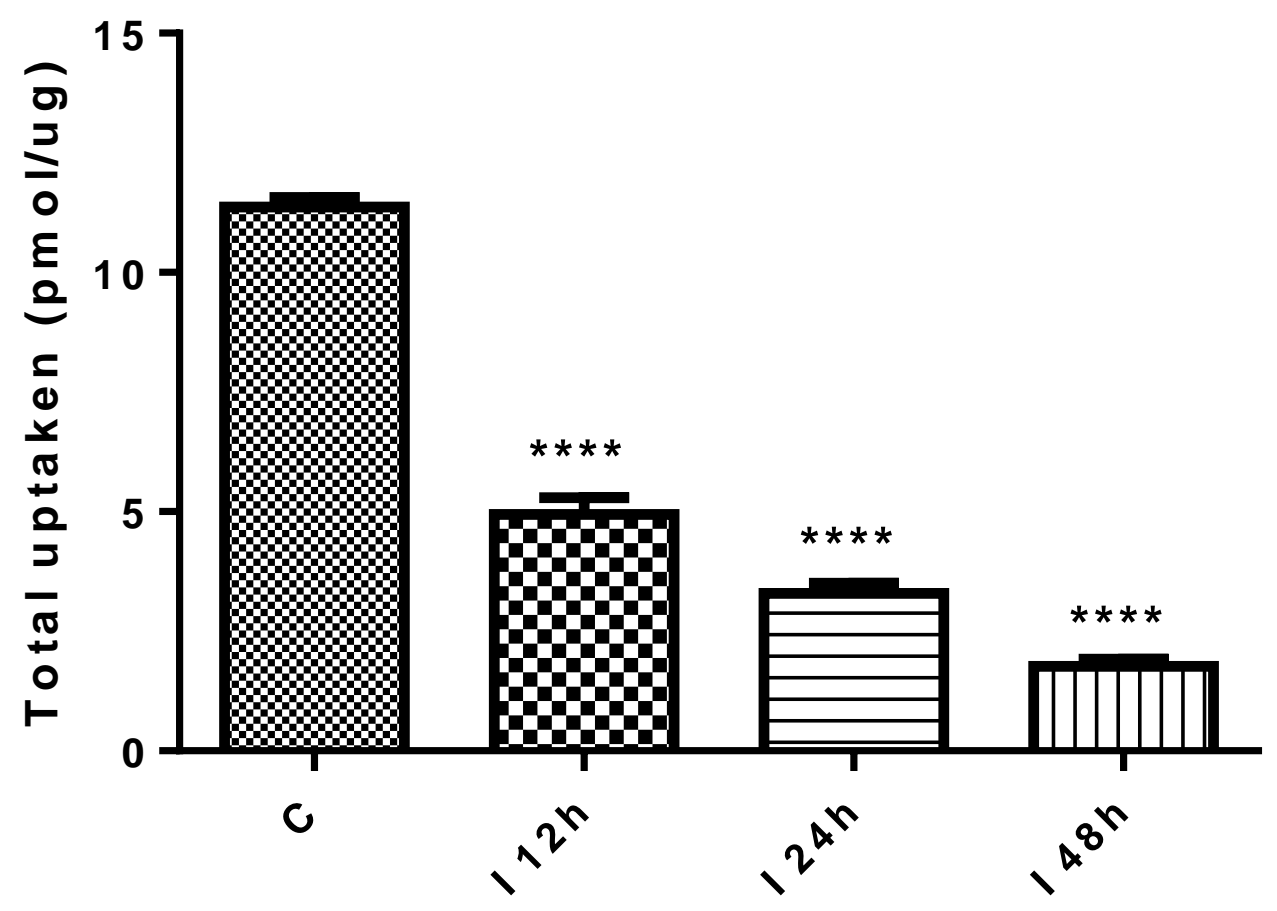

Figura 25 - Quantidade total de $\mathrm{I}^{125}$ captado por células $\mathrm{PCCl} 3$ tratadas ou não com $10^{-3} \mathrm{M}$ de Nal por 12, 24 e 48 horas. C, Controle. Os dados encontram-se representados como média \pm SEM. ${ }^{* * * *} p<0.0001$ vs $C$. Análise de variância (ANOVA) de duas vias.

\subsection{Perfil de expressão de microRNAs}

Por fim, buscou-se analisar se as modificações aqui apresentadas na expressão gênica da pendrina diante do tratamento com excesso de iodeto poderiam ser, em parte, mediadas por ação de microRNAs. No entanto, o perfil da expressão dos 264 microRNAs analisados não apresentou diferença significativa entre o grupo controle e o grupo tratados com $10^{-3} \mathrm{M} \mathrm{Nal}$ por 24 horas. O resultado completo desse ensaio está apresentado no anexo 1. 


\section{DISCUSSÃO}

Sabe-se que o iodo em excesso exerce um efeito inibitório sobre a função tiroidiana que é conhecido como Efeito Wolff-Chaikoff. Contudo essa inibição é transitória (Escape), pois ocorre uma redução da concentração de iodo no tirócito. Nesse processo a NIS vem sendo colocada como elemento chave em função da demonstração de que sua atividade e expressão são inibidas pelo iodo (ENG et al., 1999; SERRANO-NASCIMENTO et al., 2010, 2012, 2013). Nesse trabalho demonstramos que o excesso de iodo intracelular eleva a expressão da pendrina, o que aumentaria o efluxo de iodeto da célula tiroidiana, reduzindo assim a sua concentração intracelular, e contribuindo para a retomada da atividade da NIS e da função tiroidiana.

$O$ efeito do iodeto em pendrina tem sido pouco investigado, sendo ainda bastante debatido o seu papel como um transportador de iodeto na tiróide (ROUSSET, 2006; WOLFF, 2005). Sendo assim, é de extrema importância o esclarecimento de como a pendrina é regulada na tiróide. O presente estudo mostra, pela primeira vez, que o tratamento agudo com doses elevadas de iodo foi capaz de elevar a expressão gênica de pendrina, efeito que é oposto ao observado com a expressão de NIS.

Observamos aumento na expressão do mRNA de pendrina na tiróide de ratos que receberam $\mathrm{Nal}$ por 30 minutos até 48 horas, resultado que foi reproduzido em células PCCI3 (CALIL-SILVEIRA et al., 2012). Esse dado difere em parte do estudo realizado in vitro por SUZUKI e KOHN (2006), em que o mRNA de pendrina foi aumentado apenas após 6 e 12 horas de tratamento com $5 \mathrm{mM}$ de Nal. No entanto, nesse estudo, os autores utilizaram uma linhagem diferente de células de tiróide de rato, a FRTL-5. Apesar de ambas as linhagens serem derivadas da tiróide de ratos, estudos mostraram que existem importantes diferenças entre elas (FUSCO et al., 1987; KIMURA et al., 1999). Diferentemente da linhagem FRTL-5, as células PCCl3 têm se mostrado responsivas ao TSH (DENTICE et al., 2005; MUSCELA et al., 2008; PESCE et al., 2012), o que faz desta linhagem um modelo mais próximo do in vivo, e explica a resposta rápida ao iodeto (30 $\mathrm{min}$ ), que foi também observada nos nossos estudos in vivo. Ainda sobre o estudo de Suzuki e Kohn (2006), vale ressaltar que a expressão do mRNA de NIS apenas foi reduzida a partir de $12 \mathrm{~h}$ de tratamento com excesso de iodeto, enquanto estudos de nosso laboratório mostram 
uma rápida diminuição desse mRNA, em 30 minutos após tratamento (SERRANONASCIMENTO et al., 2010, 2012).

Observamos também que o tratamento com iodeto foi capaz de aumentar a expressão de mRNA do $\mathrm{ClC}-5$ nas células $\mathrm{PCCl} 3$, canal de $\mathrm{Cl}$ que é expresso na membrana apical do tirócito, e tem sido apontado como uma possível via de efluxo do iodeto para o colóide (SENOU et al., 2010; VAN DEN HOVE et al., 2006). Esse aumento ocorreu somente no tempo mais curto de tratamento (30 $\mathrm{min})$, tendo se esvaído com o passar do tempo (até $48 \mathrm{~h}$ ). Ainda, estudo realizado em colaboração com nosso grupo mostrou que células TSA-201 (um clone das células HEK 293) eram capazes que realizar o efluxo de iodeto quando transfectadas com NIS/CIC5 (BIZHANOVA et al., 2013). No entando, o efluxo de iodo foi mais expressivo quando as células foram transfectadas com NIS/PDS. Esses dados sugerem que, ambas as proteínas pendrina e CIC-5 são capazes de transportar iodeto, porém, com diferentes afinidades. Isso vai ao encontro do fato de que existem 2 transportadores apicais de iodeto no tirócito, que apresentam diferentes afinidades (GOLSTEIN, P. et al., 1992). A identificação desses transportadores ainda é motivo de investigação.

Aparentemente, o aumento do conteúdo do mRNA de pendrina em resposta ao iodo foi devido à uma rápida ação transcricional, já que foi abolido por tratamento prévio das células PCCl3 com Actinomicina D (CALIL-SILVEIRA et al., 2012). A ausência de alteração no decaimento do mRNA de pendrina após o tratamento com iodeto vai ao encontro dessa hipótese. Iniciamos então a investigação dos mecanismos pelos quais o iodeto estaria aumentando a transcrição do gene PDS, e tivemos fortes indícios de que o iodeto esteja promovendo a translocação de TTF-1 para o núcleo e induzindo aumento na transcrição de PDS. Esse fator transcricional já foi mostrado como um regulador do gene PDS (DENTICE et al., 2005). Estudos do nosso laboratório também mostram uma ação oposta do iodeto no fator transcricional PAX-8, reduzindo sua translocação para o núcleo. Este pode ser um dos mecanismos que levam à diminuição da transcrição de NIS quando há excesso de iodeto na célula tiroidiana.

Pouco se sabe sobre a regulação do promotor de PDS na tiróide. Na busca de elucidar os mecanismos pelos quais o iodeto regula a expressão de pendrina, fomos analisar a atividade do promotor de PDS frente ao tratamento com iodeto. Nossos dados mostram, no entanto, que o tratamento com iodeto não foi capaz de 
regular a atividade do promotor de PDS. Foram testados o promotor de rato e humano, e obtivemos resultado negativo com ambos.

A região onde o TTF-1 poderia estar se ligando para ativar a transcrição de PDS permanece desconhecida. Nosso experimento piloto de Chip Assay mostrou que essa região poderia estar $15 \mathrm{~kb}$ de distância à montante da região ATG (+1) do gene PDS.

Clonamos, então, a região em questão (15 kb a montante do ATG) em plasmídeo pGL3 Básico, a montante do gene da luciferase e o transfectamos em células $\mathrm{PCCl} 3$. No entanto, a atividade desse gene não foi modificada quando as células foram tratadas com iodo. Experimentos estão sendo planejados utilizando o plasmídeo pGL3 promoter, a fim de esclarecer se essa região (15 kb) poderia funcionar como um enhancer.

Buscou-se ainda investigar se o aumento do conteúdo de mRNA de pendrina estaria acarretando em um aumento do conteúdo da proteína. De fato, observamos que o conteúdo de pendrina aumentou quando ratos e células PCCl3 foram tratados com $\mathrm{Nal}$ por períodos mais longos (24 e 48 horas), sendo que o aumento da expressão da proteína na tiróide dos animais se deu após 48 horas de tratamento, enquanto nas células ele ocorreu após 24 horas. Isso condiz com a rapidez do efeito do iodeto no mRNA de pendrina (Figuras 4 e 5), que se mostrou maior nas células quando comparado aos ratos, o que pode se dever ao fato do iodeto ser adicionado diretamente ao meio de cultura, e não depender de processos relacionados à absorção de iodeto e seu transporte pelo sistema circulatório até a tiróide.

As células $\mathrm{PCCl} 3$ tratadas com doses menores de $\mathrm{Nal}$ não apresentaram aumento da expressão de pendrina. Esse evento, associado ao fato da proteína estar aumentada num tempo mais longo de tratamento, é consistente com o fato do efeito Wolff-Chaikoff requer uma alta quantidade de iodeto intracelular para ser desencadeado (BURGI, 2010). Ainda, o efeito de escape foi descrito a ocorrer em períodos mais tardios, a partir de 24-48 horas (WOLFF; CHAIKOFF, 1948).

Os resultados da imunofluorescência mostraram que após tratamento com Nal ocorreu uma marcação mais forte de pendrina nas células PCCl3 não permeabilizadas, sugerindo que a proteína marcada localiza-se na membrana plasmática. Esse efeito só é observado após 12 h de tratamento com Nal, o que é consistente com os dados do conteúdo total de pendrina. 
A insulina e o TSH já foram apontados como agentes que acarretam aumento do efluxo de iodeto em células PCCI3 (MUSCELA et al., 2008; PESCE et al., 2012). Apesar de ser bastante conhecida a regulação que o iodeto exerce na sua própria captação no tirócito, nunca havia sido investigado se ele poderia regular sua própria saída da célula. No presente estudo demonstramos que o tratamento com excesso de iodeto aumentou a taxa de seu efluxo em células PCCl3. Ainda, indo ao encontro dos dados de western blot e imunofluorescência, o aumento do efluxo só ocorreu quando as células foram tratadas com iodo por mais de 12 horas. Interessante o fato de que o aumento na taxa do efluxo de iodeto persiste mesmo quando não foi observado aumento do conteúdo total de pendrina (48 horas), sugerindo que, além do aumento no conteúdo, o iodo parece estar promovendo um aumento da atividade de pendrina, efeito que pode estar persistindo por mais tempo. Se outros transportadores estão sendo ativados com o tratamento, e acarretando em maior efluxo de iodeto, ainda precisa ser investigado. Estudo preliminar sugere uma regulação pelo iodo do $\mathrm{CIC5}$, já que o conteúdo de seu mRNA apresentou-se elevado, embora só no menor tempo de exposição ao oligoelemento (30 min).

A avaliação do perfil de expressão de miRNAs em células PCCI3 tratadas $\left(10^{-}\right.$ ${ }^{3} \mathrm{M} / 24 \mathrm{~h}$ ) vs não tratadas com iodo não revelou qualquer diferença significativa entre a triplicata do grupo tratado com a do controle (Anexo 1). Esses dados diferem dos obtidos por Fuziwara e Kimura (2014), que observaram que o tratamento com $10^{-5} \mathrm{M}$ de Nal levou a um aumento na expressão do miR-20 e miR-92. Vale ressaltar que nossos dados foram obtidos de um estudo piloto e que experimentos adicionais serão realizados para a obtenção de resultados mais consistentes

Em resumo, os resultados obtidos até o momento apontam para uma regulação extremamente rápida da expressão gênica de pendrina ao nível transcricional pelo iodeto, ação essa que se reflete no aumento do mRNA. O conteúdo da proteína também se apresentou elevado, porém nos tempos mais longos do estudo (24 e 48 h), nos quais também observamos maior marcação de pendrina na membrana, bem como uma taxa de efluxo de iodeto aumentada. Esses dados apontam para um importante papel de pendrina transportando o iodeto através da membrana apical dos tirócitos, e contribuindo para o efeito Wolff-Chaikoff e seu Escape. Assim, NIS e pendrina podem participar de forma importante no mecanismo de autorregulação da função tiroidiana pelo iodo, de forma a garantir que a concentração deste oligoelemento não se eleve demasiadamente no tirócito, o que 
poderia promover efeitos deletérios, já que se tem associado o excesso de iodo intratiroidiano ao desenvolvimento de tiroidites e, em conseqüência, hipotiroidismo.

A figura 26 abaixo sintetiza as possibilidades que acabamos de propor para explicar a participação de pendrina no Efeito Wolff-Chaikoff e seu escape. Acreditamos que frente ao aumento da oferta de iodo, ocorra, inicialmente, uma elevação da sua captação (1) e da sua concentração intracelular, o que desencadeia redução da expressão e atividade de NIS (2), com conseqüente diminuição do influxo de iodeto para a glândula. Ao mesmo tempo, a elevação intracelular da concentração de iodeto promoveria um estímulo na transcrição do gene da pendrina (2), o que resultaria no aumento do conteúdo de transcritos (3), cuja tradução, acarretaria num maior conteúdo de pendrina na membrana apical do tirócito (4), e, assim, no maior efluxo de iodeto da célula. Com a captação de iodeto reduzida, e com o seu efluxo aumentado, não restaria iodeto intracelular suficiente para sustentar o efeito de bloqueio Wolff-Chaikoff, o que levaria ao Escape desse efeito.

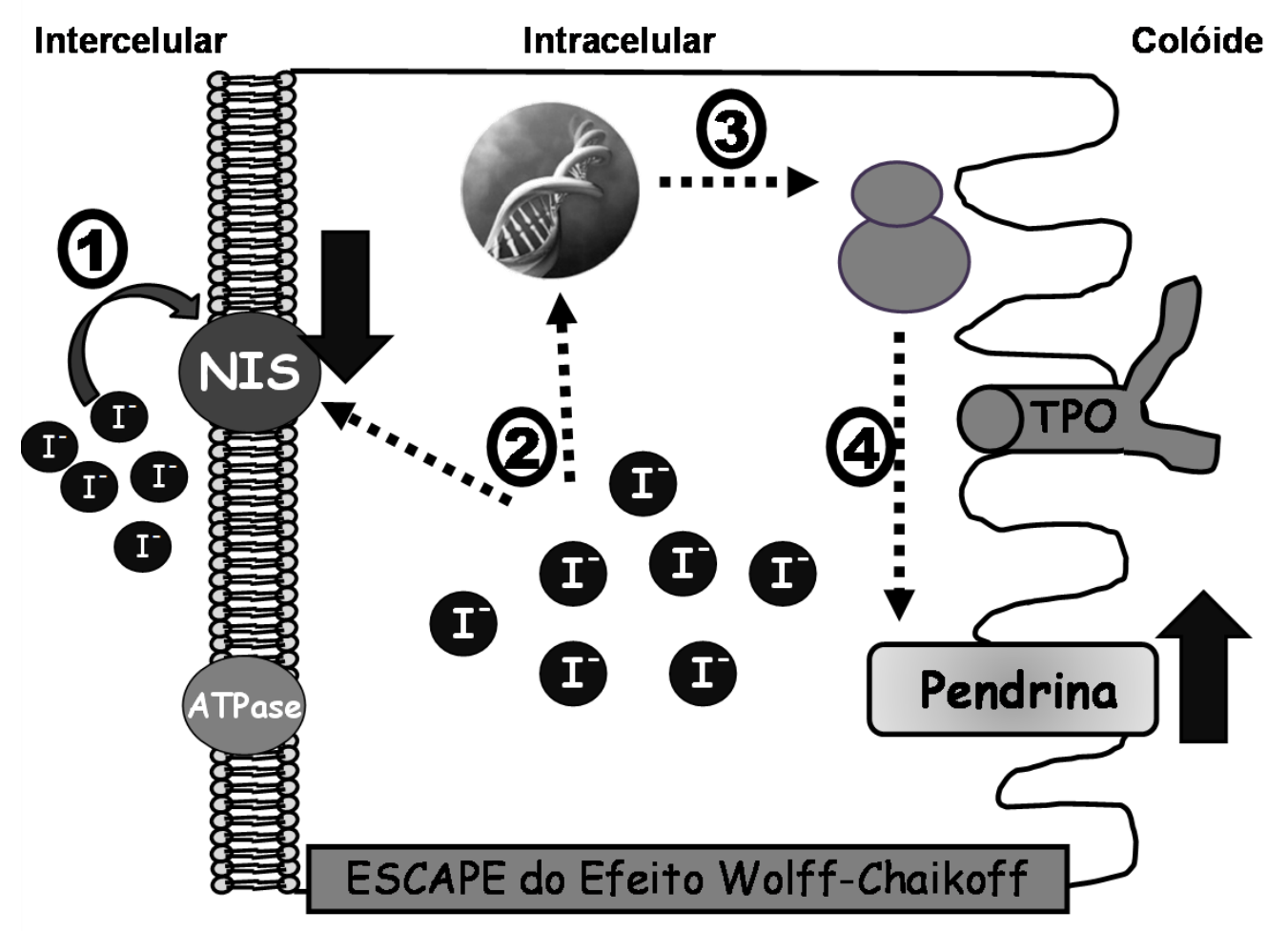

Figura 26 - Representação dos eventos acarretados pelo aumento de iodeto dentro da célula. A concomitante diminuição de NIS e aumento de Pendrina poderia contribuir para que ocorra o Escape do Efeito Wolff-Chaikoff. 


\section{REFERÊNCIAS*}

ADLER, L.; EFRATI, E.; ZELIKOVIC, I. Molecular mechanisms of epithelial cell-specific expression and regulation of the human anion exchanger (pendrin) gene. Am J Physiol Cell Physiol., v.294, p.1261-1276, 2008.

ADORNO, M.; CORDENONSI, M.; MONTAGNER, M.; DUPONT, S.; WONG, C.; HANN, B.; SOLARI, A.; BOBISSE, S.; RONDINA, M. B.; GUZZARDO, V.; PARENTI, A. R.; ROSATO, A.; BALMAIN, A.; PICCOLO, S. A Mutant-p53/Smad complex opposes p63 to empower TGF beta-induced metastasis. Cell, v.137, p.87-98, 2009.

ARAVIND, L.; KOONIN, E.V. The STAS domain - a link between anion transporters and antisigma-factor antagonists. Curr Biol., v. 10, p. 53-55, 2000.

BIDART, J. M.; MIAN, C.; LAZAR, V.; RUSSO, D.; FILETTI, S.; CAILLOU, B.; SCHLUMBERGER, M. Expression of pendrin and the Pendred syndrome (PDS) gene in human thyroid tissues. J Clin Endocrinol Metab., v.85, p.2028-2033, 2000.

BIZHANOVA, A.; CHEW, T. L.; KHUON, S.; KOPP, P. Analysis of Cellular Localization and Function of Carboxy-Terminal Mutants of Pendrin. Cell Physiol Biochem., v. 28, p. 423-434, 2011.

BIZHANOVA, A; KOPP, P. Genetics and phenomics of Pendred syndrome. Mol Cell Endocrinol., v.322, p.83-90, 2010.

BIZHANOVA, A.; CALIL-SILVEIRA, J.; NUNES M. T.; KOPP, P. (2013) Chloride Channel 5, an Alternative Apical lodide Transporter in Thyrocytes? In: THYROID 83TH ANNUAL MEETING OF THE AMERICAN THYROID ASSOCIATION. San Juan, Puerto Rico. Abstract

BRAVERMAN, L. E.; INGBAR, S. H. Changes in thyroidal function during adaptation to large doses of iodide. J Clin Invest., v.42, n.8, p.1216-31, 1963.

BURGI, H. lodine excess. Best Pract Res CI En., v. 24, p.107-115, 2010.

BURMAN, K. D.; WARTOFSKY, L. lodine Effects on the Thyroid Gland: Biochemical and Clinical aspects. Reviews in Endocrine \& Metabolic Disorders, v.1, p.19-25, 2000.

CALEBIRO,D.; PORAZZI, P.; BONOMI, M.; LISI, S.; GRINDATI, A.; DE NITTIS, D.; FUGAZZOLA, L.; MARINÒ, M.; BOTTÀ, G.; PERSANI, L. Absence of primary hypothyroidism and goiter in Slc26a4 (-/-) Mice Fed on a Low lodine Diet. J Endocrinol Invest., v.34, p. 593-8, 2010.

CALIL-SILVEIRA, J.; SERRANO-NASCIMENTO, C.; NUNES, M. T. lodide treatment acutely increases pendrin (SLC26A4) mRNA expression in the rat thyroid and the PCCl3 thyroid cell line by transcriptional mechanisms. Mol Cell Endocrinol., v. 350, p.118-124, 2012.

CAMPBELL, C.; CUCCI, R. A.; PRASAD, S.; GREEN, G. E.; EDEAL, J. B.; GALER, C. E.; KARNISKI, L. P.; SHEFFIELD, V. C.; SMITH, R. J. H. Pendred Syndrome, DFNB4, and PDS/SLC26A4 Identification of Eight Novel Mutations and Possible Genotype-Phenotype Correlations. Hum Mut., v.17, p. 403-411, 2001.

*De acordo com: ASSOCIAÇÂO BRASILEIRA DE NORMAS TÉCNICAS. NBR 6023: informação e documentação: referencias: elaboração. Rio de Janeiro, 2002 
CARDOSO, L. C.; MARTINS, D. C. L.; CAMPOS, D. V. B.; SANTOS, L. M.; COSTA,V. M. C.; ROSENTHAL, D.; VAISMAN, M.; VIOLANTE, A. H. D.; CARVALHO, D. P. Effect of iodine or iopanoic acid on thyroid Ca2+/NADPH-dependent H2O2-generating activity and thyroperoxidase in toxic diffuse goiters. Eur J Endocrinol., v. 147, p. 293-298, 2002.

CAVALIERI,R. R. Iodine Metabolism and Thyroid Physiology: Current Concepts. Thyroid, v.7, n.2, p.177-181, 1997.

COLLAS, P. The Current State of Chromatin Immunoprecipitation. Mol Biotechnol., v. 45, p.87-100, 2010.

DAÍ, G.; LEVY, O.; CARRASCO, N. Cloning and characterization of the thyroid iodide transporter. Nature, v.379, n.6564, p. 458-460, 1996.

DENEFD, J. F.; MANY, M. C.; VAN DEN HOVEB, M. F. lodine-induced thyroid inhibition and cell necrosis: two consequences of the same free-radical mediated mechanism? Mol Cell Endocrinol., v.21, p.101-103, 1996.

DENTICE, M.; LUONGO, C.; ELEFANTE, A.; AMBROSIO, R.; SALZANO, S.; ZANNINI, M.; NITSCH, R.; DI LAURO, R.; ROSSI, G.; FENZI, G.; SALVATORE, D. Pendrin is a novel in vivo downstream target gene of the ttf $-1 / \mathrm{nkx}-2.1$ homeodomain transcription factor in differentiated thyroid cells. Mol. Cell. Biol.,v.25, n. 22, p. 10171-10182, 2005.

DOHAN, O.; DE LA VIEJA, A.; PARODER, V.; RIEDEL, C.; ARTANI, M.; REED, M.; GINTER, C. S.; CARRASCO, N. The sodium/iodide Symporter (NIS): characterization, regulation, and medical significance. Endocrine Reviews, v.24, n.1, p.48-77, 2003.

DOSSENA, S.; BIZHANOVA, A.; NOFZIGER, C.; BERNARDINELLI, E.; RAMSAUER, J.; KOPP, P.; PAULMICHL, M. Identification of Allelic Variants of Pendrin (SLC26A4) with Loss and Gain of Function. Cell Physiol Biochem., v.28, 467- 476, $2011 \mathrm{a}$.

DOSSENA, S.; NOFZIGER, C.; TAMMA, G.; BERNARDINELLI, E.; VANONI, S.; NOWAK, C.; GRABMAYER, E.; KÖSSLER, S.; STEPHAN, S.; PATSCH, W.; PAULMICHL, M. Molecular and Functional Characterization of Human Pendrin and its Allelic Variants. Cell Physiol Biochem., v. 28, p.451-466, 2011b.

ELOY, C.; SANTOS, J.; CAMESELLE-TEIJEIRO, J.; SOARES, P.; SOBRINHO-SIMOES, M. TGF-beta/Smad pathway and BRAF mutation play different roles in circumscribed and infiltrative papillary thyroid carcinoma. Virchows Arch., v. 460, p.587-600, 2012.

ENG, P. H.; CARDONA, G. R.; FANG, S. L.; PREVITI, M.; ALEX, S.; CARRASCO, N.; CHIN, W. W.; BRAVERMAN, L. E. Escape from the acute Wolff-Chaikoff effect is associated with a decrease in thyroid sodium/iodide symporter messenger ribonucleic acid and protein. Endocrinology, v.140, n.8, p.3404-10, 1999.

ENG, P. H.; CARDONA, G. R.; PREVITI, M. C.; CHIN, W. W.; BRAVERMAN, L. E. Regulation of the sodium iodide symporter by iodide in FRTL-5 cells. Eur J Endocrinol., v.144, n.2, p.139-144, 2001.

EVERETT, L. A.; GLASER, B.; BECK, J. C.; IDOL, J. R.; BUCHS, A.; HEYMAN, M.; ADAWI, F.; HAZANI, E.; NASSIR, E.; BAXEVANIS, A. D.; SHEFFIELD, V. C.; GREEN, E. D. Pendred syndrome is caused by mutations in a putative sulphate transporter gene (PDS). Nat Genet., v.17, p.411-22, 1997. 
FERREIRA, A. C.; LIMA, L. P.; ARAÚJO, R. L.; MÜLLER, G.; ROCHA, R. P.; ROSENTHAL, D.; CARVALHO, D. P. Rapid regulation of thyroid sodium-iodide symporter activity by thyrotrophin and iodine. J Endocrinol., v.184, n.1, p.69-76, 2005.

FRISCHE, S.; KWON, T. H.; FROKIAER, J.; MADSEN, K. M.; NIELSEN, S. Regulated expression of pendrin in rat kidney in response to chronic $\mathrm{NH} 4 \mathrm{Cl}$ or $\mathrm{NaHCO} 3$ loading. $\mathbf{A m} \mathbf{J}$ Physiol Renal Physiol., v.284, p.584-593, 2003.

FUSCO, A.; BERLINGIERI, M. T.; DI FIORE, P. P.; PORTELLA, G.; GRIECO, M.; VECCHIO, G. One-and two-step transformations of rat thyroid epithelial cells by retroviral oncogenes. Mol. Cell. Biol., v.7, p.3365-3370, 1987.

FUZIWARA, C. S.; KIMURA, E. T. High lodine Blocks a Notch/miR-19 Loop Activated by the BRAFV600E Oncoprotein and Restores the Response to TGF $\beta$ in Thyroid Follicular Cells. Thyroid, 2014. In press.

GILLAM, M. P.; SIDHAYE, A. R.; LEE, E. J.; RUTISHAUSER, J.; STEPHAN, C. W.; KOPP, P. Functional Characterization of Pendrin in a Polarized Cell System.Evidence for pendrinmediated apical iodide efflux. J. Biol. Chem., v.279, n13, p.13004-13010, 2004.

GOLSTEIN, P.; ABRAMOW, M.; DUMONT, J. E.; BEAUWENS, R. The iodide channel of the thyroid: a plasma membrane vesicle study. Am. J. Physiol., v. 263, p. 590-597, 1992.

GOULART-SILVA, F.; de Souza P. B.; NUNES, M. T. T3 rapidly modulates TSH $\beta$ mRNA stability and translational rate in the pituitary of hypothyroid rats. Mol. Cell. Endocrinol., v. 332, p.277-282, 2011.

HAFNER, P.; GRIMALDI, R.; CAPUANO, P.; CAPASSO, G.; WAGNER, C. A. Pendrin in the mouse kidney is primarily regulated by $\mathrm{Cl}$ excretion but also by systemic metabolic acidosis. Am J Physiol Cell Physiol., v. 295, p.1658-1667, 2008.

IWASAKI, S.; TSUKAMOTO, K.; USAMI, S.; MISAWA, K.; MIZUTA, K.; MINETA, H. Association of SLC26A4 mutations with clinical features and thyroid function in deaf infants with enlarged vestibular aqueduct. J Hum Genet., v.51, p.805-10, 2006.

KIM, Y. H.; PHAM, T. D.; ZHENG, W.; HONG, S.; BAYLIS, C.; PECH, V.; BEIERWALTES, W. H.; FARLEY, D. B.; BRAVERMAN, L. E.; VERLANDER, J. W.; WALL, S. M. Role of pendrin in iodide balance: going with the flow. Am. J. Physiol. Renal. Physiol., v.297, n.4, p.F1069-F1079, 2009.

KIMURA, T.; DUMONT, J. E.; FUSCO, A.; GOLSTEIN, J. Insulin and TSH promote growth in size of $\mathrm{PC} \mathrm{Cl3}$ rat thyroid cells, possibly via a pathway different from DNA synthesis: comparison with FRTL-5 cells. Eur. J. Endocrinol., v.140, p.94-103, 1999.

KNOBEL, M.; MEDEIROS-NETO, G. Moléstias associadas à carência crônica de iodo. Arq. Bras. Endocrinol. Metab., v.48, n.1, p. 53-61, 2004.

KO, S. B.; SHCHEYNIKOV, N.; CHOI, J. Y.; LUO, X.; ISHIBASHI, K.; THOMAS, P. J.; KIM, J. Y.; KIM, K. H.; LEE, M. G.; NARUSE, S.; MUALLEM, S. A molecular mechanism for aberrant CFTR-dependent HCO3-transport in cystic fibrosis. EMBO J., v.21, p.5662-5672, 2002.

KOPP, P. Pendred's syndrome: identification of the genetic defect a century after its recognition. Thyroid, v., 9, p. 65-69, 1999. 
LACROIX, L.; MIAN, C.; CAILLOU, B.; TALBOT, M.; FILETTI, S.; SCHLUMBERGER, M.; BIDART, J. M. Pendrin, encoded by the Pendred syndrome gene, resides in the apical region of renal intercalatedcells and mediates bicarbonate secretion. Proc Natl Acad Sci U S A, v. 27, p. 4221-6, 2001.

LI, H. S.; CARAYANNIOTIS ,G. Induction of goitrous hypothyroidism by dietary iodide in SJL mice. Endocrinology, v.10, 1210/en.2007-0082. 2007.

LIVAK, K. J.; SCHMITTGEN, T. D. Analysis of relative gene expression data using real-time quantitative PCR and the $2^{-\Delta \Delta C}$. Methods, v. 25, p.402-408, 2001.

MACPHEE, D. J. Methodological considerations for improving Western blot analysis. J Pharmacol Toxicol Methods, v.61, p.171-177, 2010.

MANIATS, T.; FRITSCH, E. F.; SAMBROOK, J. Molecular Cloning - a Laboratory Manual. 2. ed. New York: Cold SApring Harbor Laboratory Press, 1989. 3 v.

MATSUO, S. E.; FIORE, A. P.; SIGUEMATU, S. M.; EBINA, K. N.; FRIGUGLIETTI, C. U.; FERRO, M. C.; KULCSAR, M. A.; KIMURA, E. T. Expression of SMAD proteins, TGFbeta/activin signaling mediators, in human thyroid tissues. Arq Bras Endocrinol Metabol., v. 54, p.406-412, 2010.

MEDEIROS-NETO,G.. lodo nutricional no Brasil: como estamos?. Arq Bras Endocrinol Metab., v.53, n.4, p. 470-474, 2009.

MORAND,S.; CHAARAOUI,M.; KANIEWSKI, J.; DE`ME,D.; OHAYON, R.; NOEL-HUDSON, M. S.; VIRION,A.; DUPUY, C. Effect of lodide on Nicotinamide Adenine Dinucleotide Phosphate Oxidase Activity and Duox2 Protein Expression in Isolated Porcine Thyroid Follicles. Endocrinology., v. 144, n.4, p. 1241-1248, 2003.

MORTON, M. E.; CHAIKOFF, I. L.; ROSENFELD, S. Inhibiting effect of inorganic iodide on the formation in vitro of thyroxine and diiodotyrosine by surviving thyroid tissue. J. Biol. Chem., v.154, n.2, p. 381, 1944.

MUSCELlA, A., MARSIGLIANTE, S., VERRI, T., URSO, L., DIMITRI, C., BOTTÀ, G., PAULMICHL, M., BECK-PECCOZ, P., FUGAZZOLA, L., STORELLI, C. PKC-epsilondependent cytosol-to-membrane translocation of pendrin in rat thyroid $\mathrm{PC} \mathrm{Cl3}$ cells. $\mathbf{J}$ Cell Physiol., v.217, p.103-112. 2008.

NOFZIGER, C.; DOSSENA,S.; SUZUKI,S.; IZUHARA,K.; PAULMICHL, M. Pendrin Function in Airway Epithelia. Cell Physiol Biochem., v. 28, p.571-578, 2011.

OHANA, E.; YANG, D.; SHCHEYNIKOV, N.; MUALLEM, S. Diverse transport modes by the Solute Carrier 26 family of anion transporters. J. Physiol., v.587, n.10, p.2179-2185, 2009.

PANNEELS, V.; MACOURSI, P.; VAN DEN BERGEN, H.; BRAEKMAN,J.C.; VAN SANDE, J.; BOEYNAEMS J.M. Biosynthesis and Metabolism of 2-lodohexadecanal in Cultured Dog Thyroid Cells. J Biol Chem., v.271, p.23006-23014, 1996.

PANNEELS,V.; VAN DEN BERGEN, T. H.; JACOBY, C.; BRAEKMAN, J. C.; VAN SANDE, J.; DUMONT, J. E.; BOEYNAEMS, J. M. Inhibition of $\mathrm{H}, \mathrm{O}$, production by iodoaldehydes in cultured dog thyroid cells. Mol Cell Endocrinol., v.102, p.167-176, 1994. 
PAVAN, R.; JESUS, A. M. X.; MACIEL, L. M. Z. A Amiodarona e a Tiróide. Arq Bras Endocrinol Metab., v.48, n.1, p.176-182, 2004.

PECH, V.; KIM, H. Y.; WeINSTEIN, M. A.; EVERETT, A. L.; PHAM, D. T.; WALL, M. S. Angiotensin II increases chloride absorption in the cortical collecting duct in mice through a pendrin-dependent mechanism. Am J Physiol Renal Physiol.,v.292, p.914-920, 2007.

PERA, A; DOSSENA, S.; RODIGHIERO, S.; GANDIA, M.; BOTTA, G.; MEYER, G.; MORENO, F.; NOFZIGER, C.; HERNANDEZ-CHICO, C.; PAULMICHL, M. Functional assessment of allelic variants in the SLC26A4 gene involved in Pendred syndrome and nonsyndromic EVA. Proc Natl Acad Sci USA, v.105, p.18608-18613, 2008.

PEREIRA, A.; BRAEKMAN, J. C.; DUMONT, J. E.; BOEYNAEMS,J. M. Identification of a Major lodolipid from the Horse Thyroid Gland as 2-lodohexadecanal. J Biol Chem., v.965., p.17018-17025, 1990.

PESCE, L., BIZHANOVA, A., CARABALLO, J. C., WESTPHAL, W., BUTTI, M. L., COMELLAS, A., KOPP, P. TSH Regulates Pendrin Membrane Abundance and Enhances lodide Efflux in Thyroid Cells. Endocrinology, v.153, p.512-21, 2012.

PORRA, V.; BERNIER-VALENTIN, F.; TROUTTET-MASSON, S.; BERGER-DUTRIEUX, N.; PEIX, J. L.; PERRIN, A.; SELMI-RUBY, S.; ROUSSET, B. Characterization and semiquantitative analyses of pendrin expressed in normal and tumoral human thyroid tissues. J. Clin. Endocrinol. Metab., v. 87, n. 4, p. 1700-1707, 2002.

QUENTIN, F.; CHAMBREY, R.; TRINH-TRANG-TAN, M. M.; FYSEKIDIS, M.; CAMBILLAU, M.; PAILLARD, M.; ARONSON, P.S.; ELADARI, D. The Cl-/HCO3- exchanger pendrin in the rat kidney is regulated in response to chronic alterations in chloride balance. Am $\mathbf{J}$ Physiol Renal Physiol., v.287, p. 1179-1188, 2004.

REARDON, W.; TREMBATH, R.C. Pendred syndrome. J. Med. Genet., v.33, p.1037$1040,1996$.

REARDON, W.; COFFEY, R.; PHELPS, P. D.; LUXON, L. M.; STEPHENS, D.; KENDALLTAYLOR, P.; BRITTON, K. E.; GROSSMAN, A.; TREMBATH, R. Pendred syndrome: 100 years of underascertainement, QJM., v.90, p. 443-447, 1997.

REARDON, W.; OMAHONEY, C. F.; TREMBATH, R.; JAN, H.; PHELPS, P. D. Enlarged vestibular aqueduct: a radiological marker of pendred syndrome, and mutation of the PDS gene. QJM., v.93, p.99-104, 2000.

ROBINSON, B. G., FRIM, D. M.; SCHWARTZ, W. J.; MAJZOUB, J. A. Vasopressin mRNA in the suprachiasmatic nuclei: Daily regulation of polyadenylate tail length. Science, v. 24, p.342-343, 1988.

ROUSSET, B. How many iodide transporters are there? How many true iodide transporters do we know? Hot Thyroidology, p.1, 2006.

ROYAUX, I. E.; SUZUKI, K.; MORI, A.; KATOH, R.; EVERETT, L. A.; KOHN, L. D.; GREEN, E. D. Pendrin, the protein encoded by the Pendred syndrome gene (PDS), is an apical porter of iodide in the thyroid and is regulated by thyroglobulin in FRTL-5 cells. Endocrinology, v.141, n.2, p.839-845, 2000.

ROYAUX, I. E.; WALL, S. M.; KARNISKI, L. P.; EVERETT, L. A.; SUZUKI, K.; KNEPPER, M. A.; GREEN, E. D. Pendrin, encoded by the Pendred syndrome gene, resides in the apical 
region of renal intercalated cells and mediates bicarbonate secretion. Proc Natl Acad Sci USA, v. 98, p. 4221-4226, 2001.

SCINICARIELLO, F.; MURRAY, H. E.; SMITH, L.; WILBUR, S.; FOWLER, B. A. Genetic factors that might lead to different responses in individuals exposed to perchlorate. Environ Health Perspect., v.113, p.1479-1484, 2005.

SCOTT, D.; WANG, R.; KREMAN, T. M.; SHEFFIELD,V. C.; KARNISKI,L. P. The Pendred syndrome gene encodes a chloride-iodide transport protein. Nat. Genet., v.21,p. 440-443, 1999.

SCOTT, D. A.; KARNISKI, L. P. Human pendrin expressed in Xenopus laevis oocytes mediates chloride/formate exchange. Issue., v. 278, n.1, p.207-211, 2000.

SCOTT, D. A.; WANG, R.; KREMAN, T. M.; ANDREWS, M.; MCDONALD, J. M.; BISHOP, J. R.; SMITH, R. J.; KARNISKI, L. P.; SHEFFIELD, V. C. Functional differences of the PDS gene product are associated with phenotypic variation in patients with Pendred syndrome and non-syndromic hearing loss (DFNB4). Hum Mol Genet., v.9, p.1709-1715, 2000.

SENOU, M.; C.; KHALIFA, M.; THIMMESCH, F.; JOURET, O.; DEVUYST, V.; COL, J.N.; AUDINOT, P.; LIPNIK, J. C.; MORENO, J. V.; SANDE, J. E.; DUMONT, M. C.; MANY, I.; COLIN, M.; GERARD, A. C. A Coherent Organization of Differentiation Proteins Is Required to Maintain an Appropriate Thyroid Function in the Pendred Thyroid. J Clin Endocrinol Metab., v. 95, p. 4021-4030, 2010.

SERAPHIM, P. M.; NUNES, M. T.; GIANNOCCO, G.; MACHADO, U. F. Age related obesityinduced shortening of GLUT4 mRNA poly(A) tail length in rat gastrocnemius skeletal muscle. Mol. Cell. Endocrinol., v. 276, p.80-87, 2007.

SERRANO-NASCIMENTO, C.; CALIL-SILVEIRA, J.; NUNES, M. T. New insights about the posttranscriptional mechanisms triggered by iodide excess on sodium/iodide symporter (NIS) expression in PCCl3 cells. Mol Cell Endocrionol., v.349, p. 154-61, 2012.

SERRANO-NASCIMENTO, C.; CALIL-SILVEIRA, J.; NUNES, M. T. Posttranscriptional regulation of sodium-iodide symporter (NIS) mRNA expression in the rat thyroid gland by acute iodide administration. Am J Physiol. Cell Physiol., v.298, p. 893-9, 2010.

SERRANO-NASCIMENTO, C.; DA SILVA TEIXEIRA S.; NICOLA, J.P.; NACHBAR, R. T.; MASINI-REPISO, A. M.; NUNES, M. T. The Acute Inhibitory Effect of lodide Excess on Sodium/lodide Symporter Expression and Activity Involves the PI3K/Akt Signaling Pathway.

Endocrinology, v.155, p.1145-1156, 2014.

SHARMA, A. K.; YE, L.; BAER, C. E.; SHANMUGA-SUNDARAM, K.; ALBER, T.; ALPER, S. L.; RIGBY, A. C. Solution structure of the guanine nucleotide-binding STAS domain of SLC26-related SulP protein Rv1739c from Mycobacterium tuberculosis. J Biol Chem., v.286, p.8534-8544, 2011.

SHCHEYNIKOV, N.; YANG, D.; WANG, Y.; ZENG, W.; KARNISKI,L.P.; SO, I.; WALL, S. M.; MUALLEM, S. The Slc26a4 transporter functions as an electroneutral $\mathrm{Cl}-/ \mathrm{l}-/ \mathrm{HCO} 3-$ exchanger: role of Slc26a4 and Slc26a6 in I- and HCO3- secretion and in regulation of CFTR in the parotid duct. J Physiol., v.586, n.16, p.3813-3824, 2008.

SOBELL, H. M. Actinomycin and DNA transcription. Proc Natl Acad Sci., v. 82, p.53285331, 1985. 
SOlEIMANI, M.; GREELEY, T.; PETROVIC, S.; WANG, Z.; AMLAL, H.; KOPP, P.; BURNHAM, C.E. Pendrin: an apical Cl-/OH-/HCO3- Exchanger in the Kidney Cortex. Am J Physiol Renal Physiol., v.280, p.356-364, 2001.

SPITZWEG, C.; MORRIS, J. C. The sodium iodide symporter: its pathophysiological and therapeutic implications. Clin Endocrinol., v. 57, p.559-574, 2002.

SUZUKI, K.; KOHN, L. D. Differential regulation of apical and basal iodide transporters in the thyroid by thyroglobulin. J Endocrinol, v.189, p. 247-255, 2006.

TAYLOR, J. P.; METCALFE, R. A.; WATSON, P. F.; WEETMAN, A. P.; TREMBATH, R. C. Mutations of the PDS gene, encoding pendrin, are associated with protein mislocalization and loss of iodide efflux: implications for thyroid dysfunction in Pendred syndrome. J Clin Endocrinol Metab., v.87, p.1778-1784, 2002.

USAMI, S.; ABE, S.; WESTON, M. D.; SHINKAWA, H.; VAN CAMP, G.; KIMBERLING, W. J. Non-syndromic hearing loss associ-ated with enlarged vestibular aqueduct is caused by PDS mutations. Hum Genet., v. 104, p.117-200, 1999.

VAISMAN, M.; ROSENTHAL, D.; CARVALHO, D. P. Enzimas Envolvidas na Organificação Tireoideana do lodo. Arq. Bras. Endocrinol. Metab., v.48, n.1, p.9-15, 2004.

VALLET, M.; PICARD, N.; LOFFING-CUENI, D.; FYSEKIDIS, M.; BLOCH-FAURE, M.; DESCHÊNES, G.; BRETON, S.; MENETON, P.; LOFFING, J.; ARONSON, P. S.; CHAMBREY, R.; ELADARI, D. Pendrin regulation in mouse kidney primarily is chloridedependent. J Am Soc Nephrol., v.17:, p.2153-2163, 2006.

VAN DEN HOVE, M. F.; CROIZET-BERGER, K.; JOURET, F.; GUGGINO, S. E.; GUGGINO, W. B.; DEVUYST, O.; COURTOY, P. J. The loss of the chloride channel, CIC-5, delays apical iodide efflux and induces a euthyroid goiter in the mouse thyroid gland. Endocrinology, v.147, p.1287-1296, 2006.

VERLANDER, J. W.; HASSELL, K. A.; ROYAUX, I. E.; GLAPION, D. M.; WANG, M. E.; EVERETT, L. A.; GREEN, E. D.; WALL, S. M. Deoxycorti-costerone upregulates PDS (Slc26a4) in mouse kidney: role of pendrin in mineralocorticoid-induced hypertension. Hypertension, v.42, p.356-362, 2003.

WOLFF, J.;CHAIKOFF, I. L. Plasma inorganic iodide as a homeostatic regulator of thyroid function. J. Biol Chem., v. 174, p.555-564, 1948.

WOLFF, J. What is the role of pendrin? Thyroid, v. 15, p. 346-348, 2005.

YANG, J. J.; TSAI, C. C.; HSU, H. M.; SHIAO, J. Y.; SU, C. C.; LI, S. Y. Hearing loss associated with enlarged vestibular aqueduct and Mondini dysplasia is caused by splice-site mutation in the PDS gene. Hear Res., v.199, p.22-30, 2005.

YEN, P. M. Physiological and molecular basis of thyroid hormone action. Physiological reviews, v.81, p.1097-142, 2001.

YOON, J. S.; PARK, H. J.; YOO, S. Y.; NAMKUNG, W.; JO, M. J.; KOO, S. K.; PARK, H. Y.; LEE, W. S.; KIM, K. H.; LEE, M. G. Heterogeneity in the processing defect of SLC26A4 mutants. J Med Genet., v.45, p.411-419, 2008.

YOSHIDA, A.; TANIGUCHI, S.; HISATOME, I.; ROYAUX, I. E.; GREEN, E. D.; KOHN, L. D.; SUZUKI, K. Pendrin is an iodidespecific apical porter responsible for iodide efflux from thyroid cells. J Clin Endocrinol Metab., v.87,p.3356-3361, 2002. 
YOSHIDA, A.; HISATOME, I.; TANIGUCHI, S.; SASAKI, N.; YAMAMOTO, Y.; MIAKE, J.; FUKUI, H.; SHIMIZU, H.; OKAMURA, T.; OKURA, T.; IGAWA, O.; SHIGEMASA, C.; GREEN, E. D.; KOHN, L. D.; SUZUKI, K. Mechanism of iodide/chloride exchange by pendrin. Endocrinol., v.145, n.9:430, p.1-8, 2004.

ZIMMERMANN, M. B. lodine requirements and the risks and benefits of correcting iodine deficiency in populations. J Trace Elem Med Biol., v. 22, p. 81-92, 2008. 
ANEXOS

Anexo 1

Relatório da EXIQON: 


\section{MicroRNA Array Services Final Report}

Project:

Customer:

Company/Institute:

Date:
Rat thyroid cell iodide treatment (Ref code: 2510)

Jamile Silveira

Northwestern University

Monday, September 9, 2013

performed by

Exiqon A/S

Company Reg. No. (CVR) 18984431

Skelstedet 16

2950 Vedbæk

Denmark 


\section{Contents}

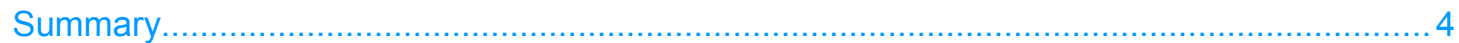

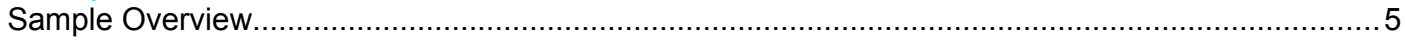

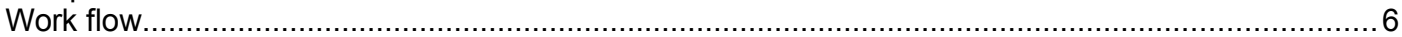

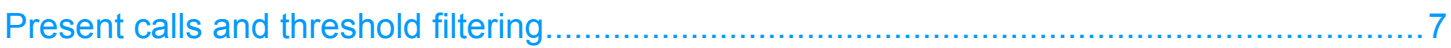

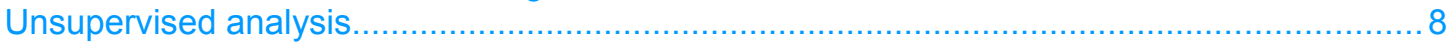

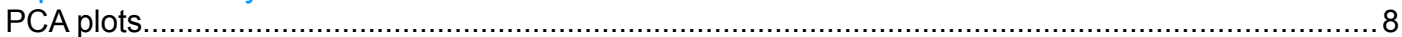

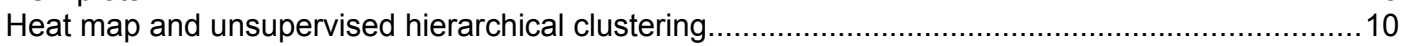

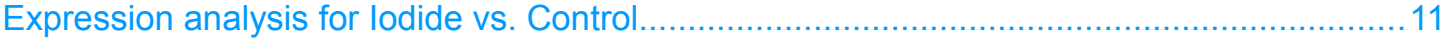

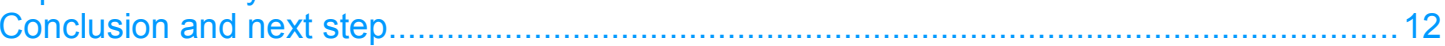

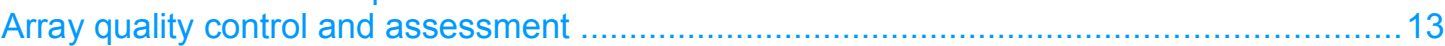

Array slide quality control using spike-ins (labeling controls) ...................................................13

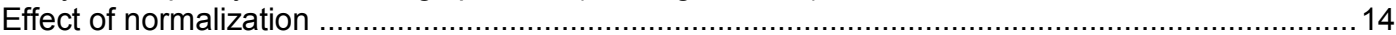

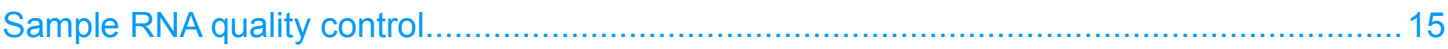

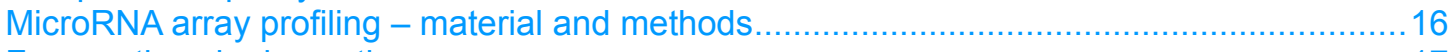

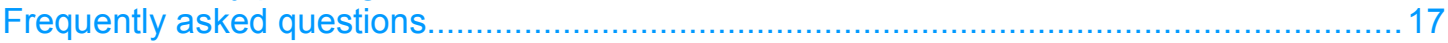

Validating your array results with miRCURY LNATM Universal RT microRNA PCR ...............19

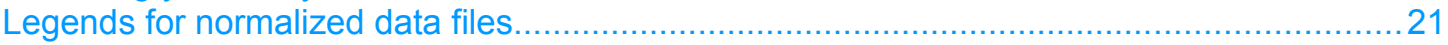

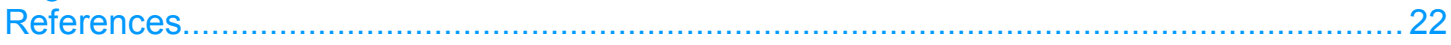

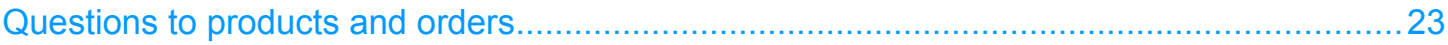

\section{Additional files provided:}

MAplots folder Presentation of data 'before' and 'after' normalization in MA plots for each slide.

Raw data folder

Containing raw data txt-files, GAL file, samplesinfo file, and legends for raw data files

ThresholdFilteredData.xlsx

Present call analysis

ExpAnalysis1.xlsx

Expression analysis 1 
Product specifications

\begin{tabular}{|l|l|}
\hline Array product number & 208520 \\
\hline Array version & 7 th Gen \\
\hline Array batch number & 35016 \\
\hline miRBase version & 20 \\
\hline
\end{tabular}




\section{Summary}

Dear Dr. Jamile Silveira

We have now finalized the analysis of the samples you submitted. Please find a summary of our findings below, and detailed information in the attached file ExpressionAnalysis.xls.

The samples were labeled using the miRCURY LNA ${ }^{\mathrm{TM}}$ microRNA Hi-Power Labeling Kit, $\mathrm{Hy} 3^{\mathrm{TM}} / \mathrm{Hy} 5^{\mathrm{TM}}$ and hybridized on the miRCURY LNA ${ }^{\mathrm{TM}}$ microRNA Array (7th Gen) following the scheme you outlined in the sample submission form.

The technical data quality assessment showed that the labeling was successful as all capture probes for the control spike-in oligo nucleotides produced signals in the expected range. Following normalization of the quantified signals (background corrected) using the global Lowess regression algorithm, we have performed an unsupervised as well as supervised data analysis.

The data analysis shows that the samples do not appear to cluster according to their biological groups indicating that other factors than the sample groups are causing the largest variation on the samples.

In conclusion, the microRNA expression profiling has been completed on your samples. The microRNA profiling did not detect any microRNAs, out of the total number analyzed by the miRCURY ${ }^{\mathrm{TM}}$ LNA array, that are differentially expressed in the different samples.

Exiqon's miRCURY LNA ${ }^{\mathrm{TM}}$ product line offers many tools for validating potentially regulated microRNAs by qPCR, in situ hybridization, Northern blot or microRNA inhibition. For more information please follow the link: www.exiqon.com/microRNA-products.

If you have questions to this report, please do not hesitate to contact us at DxServices@exiqon.com.

Exiqon Services Exiqon A/S 


\section{Sample Overview}

Table 1 below lists the samples included in the analysis.

\begin{tabular}{ccc}
\hline Slide \# & Name & Group \\
\hline 1 & I & lodide \\
\hline 2 & I & lodide \\
\hline 3 & C 2 & Control \\
\hline 4 & C 1 & Control \\
\hline 5 & C 3 & Control \\
\hline 6 & I 2 & lodide \\
\hline
\end{tabular}

Table 1: The above table summarizes the samples included in the study, and the sample classes which are used for the data analysis. 


\section{$\underset{\text { Seek Find exiti }}{\operatorname{EXN}}$}

\section{Work flow}

\section{RNA QC}

Prior to initiating the analysis your samples have been subject to RNA quality control in order to assess the integrity of the RNA, its content of small RNA and its concentration.

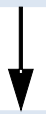

\section{Labeling and Hybridization}

Our the miRCURY LNA ${ }^{\text {TM }}$ microRNA Hi-Power Labeling Kit allows highly efficient and uniform labeling of microRNAs with minimal sequence bias. Using Tecan hybridization stations the hybridization and washing steps are fully automated for excellent reproducibility.

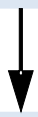

\section{Data collection and analysis}

Arrays are scanned with highly sensitive equipment in ozone free environment to reduce day-to-day variation to a minimum. Image analysis is then performed to quantify the signals on the array.

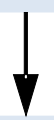

\section{Technical quality assessment}

Before proceeding with data normalization a technical quality assessment is performed based on results from spike in controls, flagging of spots, background intensity levels and signal intensity distribution.

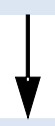

\section{Data collection and analysis}

The data obtained is normalized using methods applicable to the performed experiment. Depending on the experimental setup and the size of the project the relevant data analysis will be applied.

Figure 1: Outline of work flow 


\section{EXIQON \\ Seek Find Verify}

\section{Present calls and threshold filtering}

The background threshold was calculated for each individual microarray slide as 1.2 times the $25^{\text {th }}$ percentile of the overall signal intensity of the slide. MicroRNAs with intensities above threshold in less than $20 \%$ (or 2) of the samples were removed from the final dataset used for the expression analysis. For the present data set a total of 437 probes were discarded by this filtering procedure. The result of the threshold filtering may be found in the file ThresholdFilteredData.xlsx.

Figure 2 shows a summary of the present calls for each sample, i.e. the number of microRNAs above the background threshold. Biologically identical samples should have present call numbers in the same range.

The obtained number of present calls are within the expected range, and highly comparable for all samples.

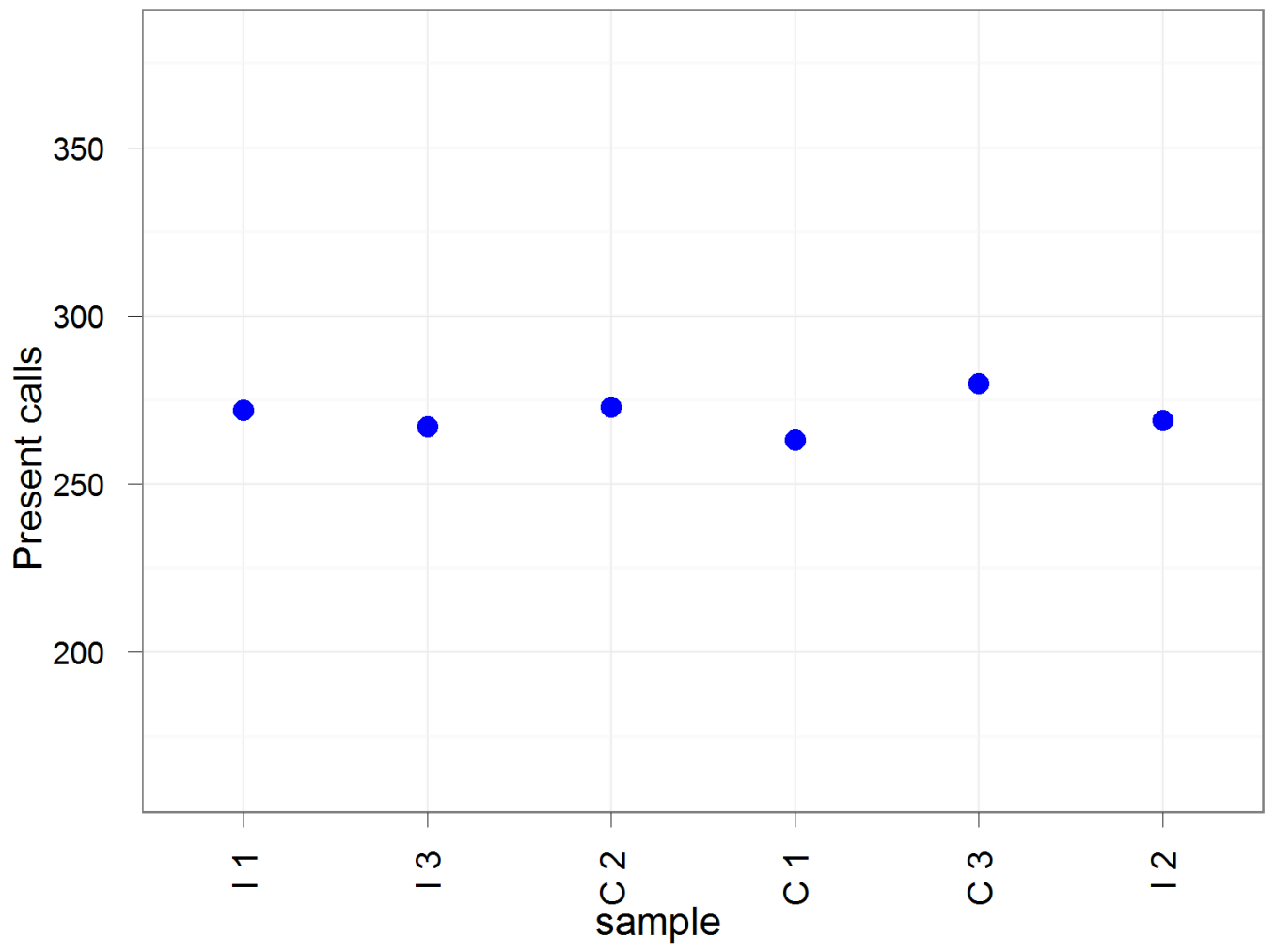

Figure 2: Plot showing number of microRNAs detectable above background threshold for each sample (out of a total of 713 possible microRNAs). 


\section{EXIQON \\ Seek Find Verify}

\section{Unsupervised analysis}

\section{PCA plots}

Principal Component Analysis (PCA) is a method used to reduce the dimensions of large data sets and is therefore a useful way to explore the naturally arising sample classes based on the expression profile. By including the top 50 microRNAs that have the largest variation across all samples, an overview of how the samples cluster based on this variance is obtained. If the biological differences between the samples are pronounced, this will be a primary component of the variation. This leads to separation of samples in different regions of a PCA plot corresponding to their biology. If other factors, e.g. sample quality, inflict more variation on the samples, the samples will not cluster according to the biology. For the unsupervised analysis a small subset of microRNAs have been excluded. Please see the FAQ section for further details.

We provide two illustrations of the result of the PCA. A traditional PCA plot (Figure 3 below), and a matrix plot (Figure 4).

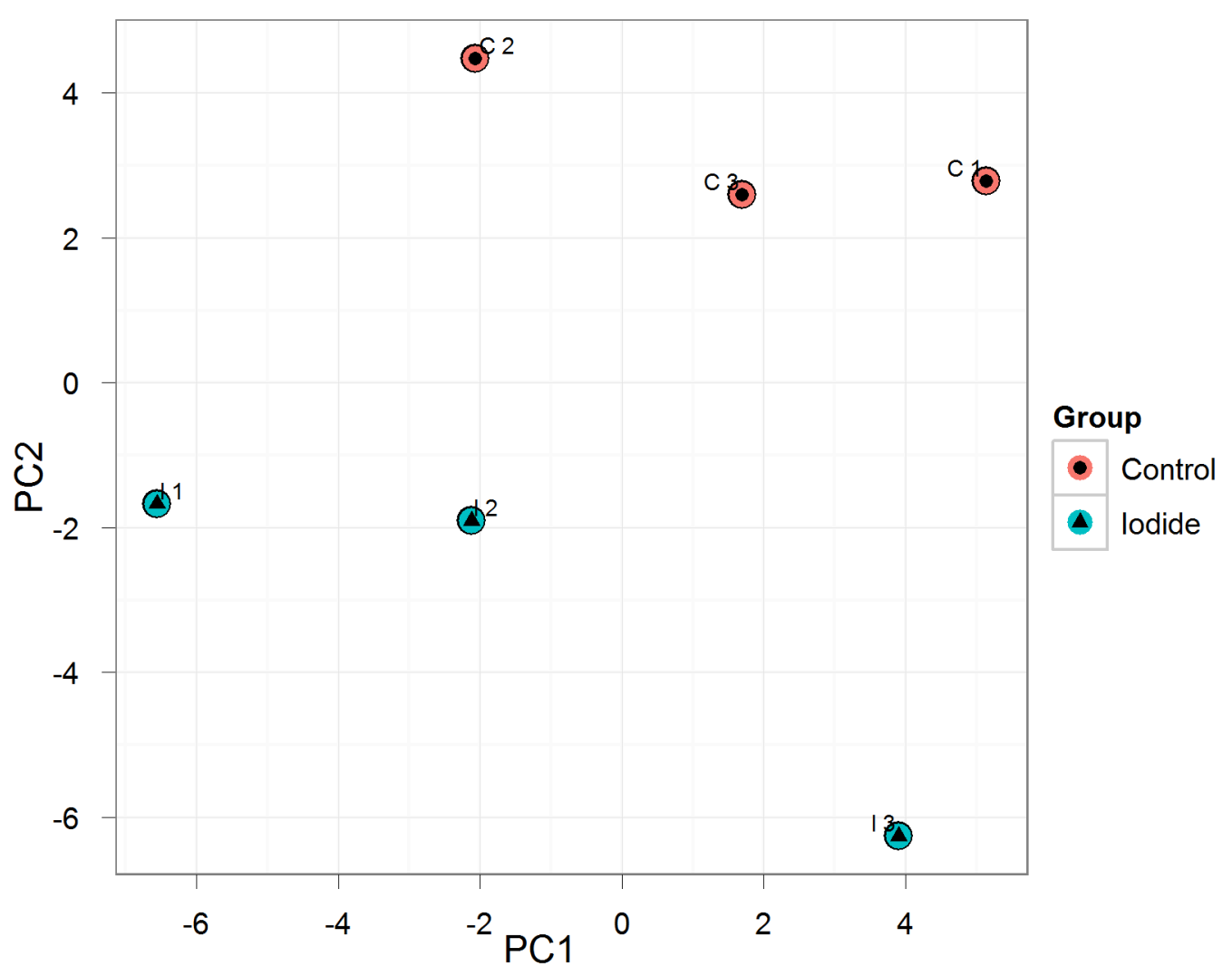

Figure 3: Traditional PCA plot. The principal component analysis was performed on all samples, and on the top 50 microRNAs with the highest standard deviation. The normalized log ratio values have been used for the analysis. The features have been shifted to be zero centered, (i.e. the mean value across samples is shifted to 0 ) and scaled to have unit variance (i.e. the variance across samples is scaled to 1) before the analysis. 


\section{EXIQON \\ Seek Find Verify}

The matrix PCA plot gives the possibility to identify variation patterns related to biological or technical factors, e.g. for a given project, PC1 and PC2 could describe variation related to sample groups or treatments, whereas PC3 and later PC's may describe underlying or less variable factors like sample preparation conditions, operator, storage time etc.
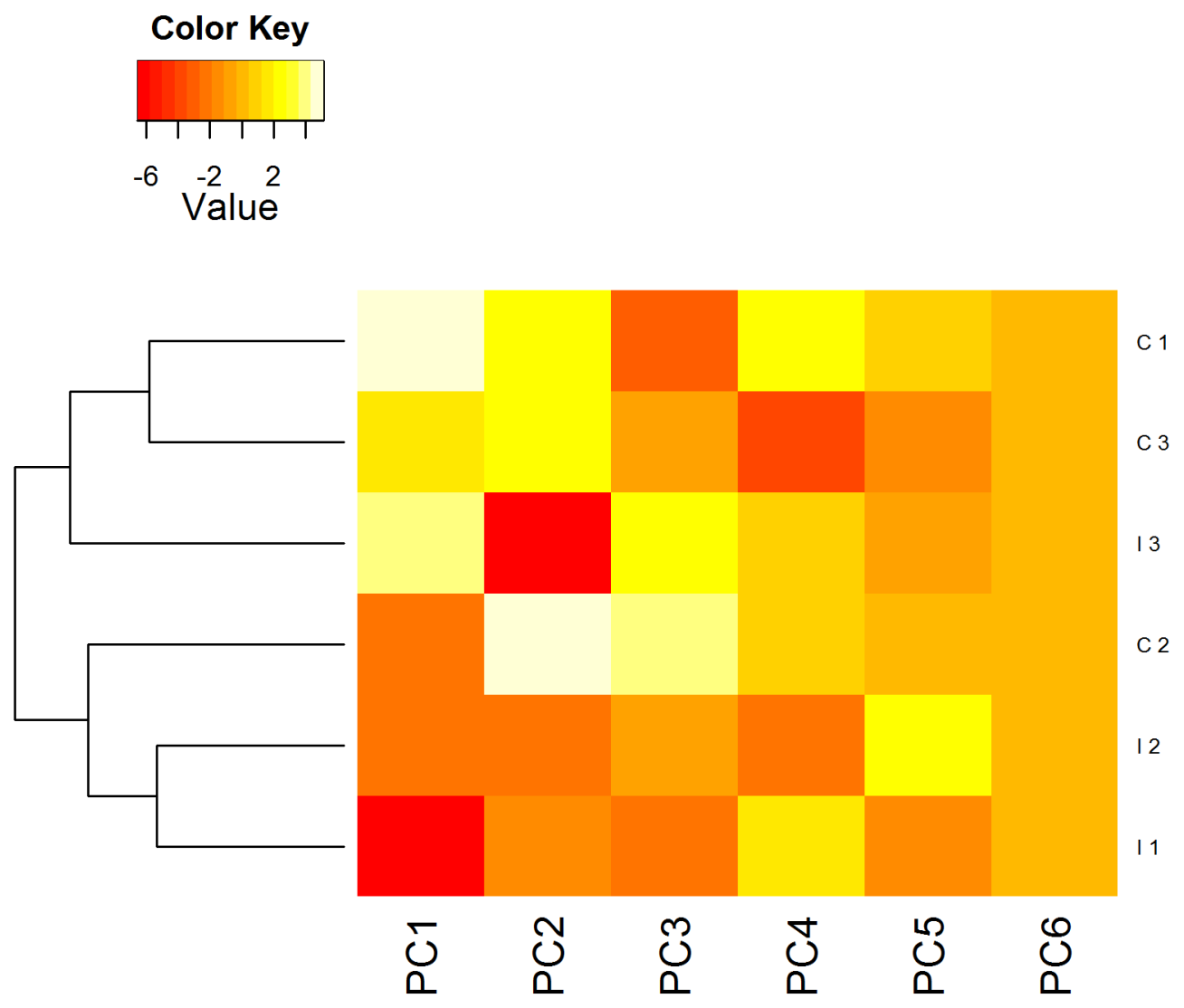

Figure 4: Matrix PCA plot. As for the traditional plot the analysis was performed on all samples, and on the top 50 microRNAs with the highest standard deviation. The normalized log ratio values have been used for the analysis. The features have been shifted to be zero centered, (i.e. the mean value across samples is shifted to 0 ) and scaled to have unit variance (i.e. the variance across samples is scaled to 1) before the analysis. 


\section{EXIQON \\ Seek Find Verify}

\section{Heat map and unsupervised hierarchical clustering}

The heat map diagram shows the result of a two-way hierarchical clustering of microRNAs and samples. The clustering is done using the complete-linkage method together with the euclidean distance measure. Each row represents a microRNA and each column represents a sample. The microRNA clustering tree is shown on the left. The color scale illustrates the relative expression level of microRNAs. Red color represents an expression level below the reference channel, and green color represents expression higher than the reference.

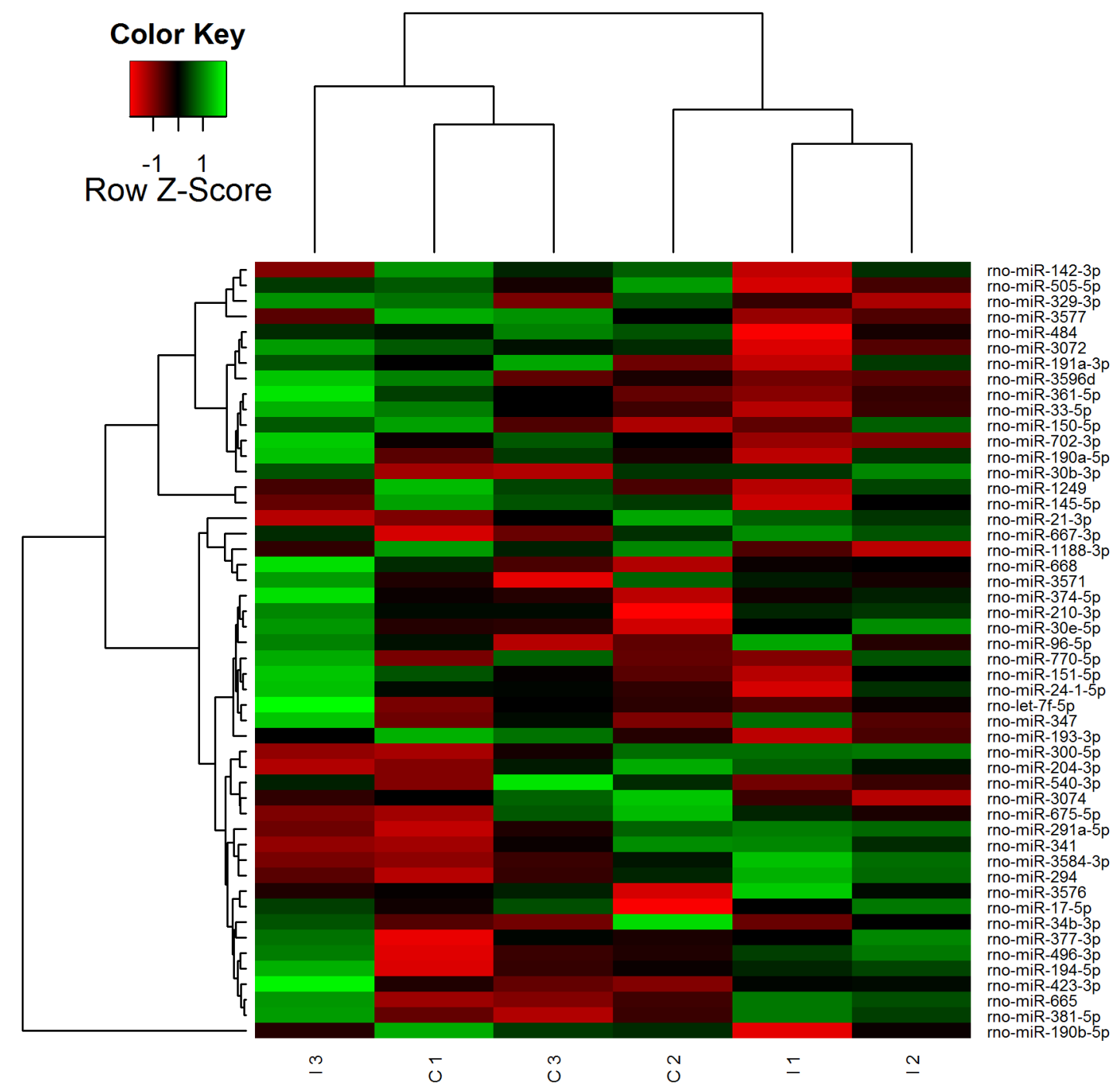

Figure 5: Heat Map and Unsupervised Hierarchical Clustering. The clustering was performed on all samples, and on the top 50 microRNAs with highest standard deviation. A small subset of microRNAs have been excluded from the heatmap. Please see the FAQ section for further details. The normalized log ratio values have been used for the analysis. 


\section{Expression analysis for lodide vs. Control}

An expression analysis for lodide vs. Control has been performed. The results of this analysis are found below and in the ExpAnalysis1.xIsx file

Due to the high number of genes being tested in parallel, microarrays are prone to give false positive results - i.e. genes that are found to be statistically different between two conditions, but are not in reality. The false positive rate can be controlled by multiple testing correction that adjust $p$-values derived from multiple statistical tests. For this expression analysis, the calculated $p$-values were based on moderated t-statistics. Furthermore, the Benjamini and Hochberg multiple testing adjustment method has been applied to the $p$-values.

All calculations have been done in the software R/bioconductor using mainly the limma package.

The microRNA profiling did not identify any significantly differentially expressed microRNAs in the different samples (that is no microRNAs where the p-value is less than 0.05 was identified), out of the total number of microRNAs analyzed (264) by the miRCURY LNA ${ }^{\text {TM }}$ microRNA Array.

Note that a complete table with results for all microRNAs can be found in the additional ExpAnalysis1.xlsx file. 


\section{Conclusion and next step}

In conclusion the expression profiling of your samples has been completed. The technical performance of the experiment showed excellent correlation between the 52 spike-ins included in the labeling reaction. In addition, the obtained "present call rates" are similar for all samples indicating comparable sample quality.

From the unsupervised PCA analysis and two-way hierarchical clustering it is clear that the microRNA profile of the samples do not cluster based on iodide treatment. This is also evident from the lack of significantly differentially expressed microRNAs found in the t-test. The PCA plot shows that the two groups are separated by the secondary component, whereas there is pronounced intra-group variation in the primary component. The combination of few replicates per group and the large intra-group variation prevents the identification of significantly differentially expressed microRNAs.

We would like to help you understand the data presented in this report and how best to proceed with your subsequent experiments. If you would like to arrange a time to discuss the data with us in more detail, please do not hesitate to contact DXServices@exiqon.com and we will be pleased to arrange a phone call with you. 


\section{Array quality control and assessment}

\section{Array slide quality control using spike-ins (labeling controls)}

Spike-in controls were added in various concentrations in both the Hу $3^{\mathrm{TM}}$ and the $\mathrm{Hy} 5^{\mathrm{TM}}$ labeling reactions giving the opportunity to evaluate the labeling reaction, hybridization, and the performance of the array experiment in general. The high correlation $\left(R^{2}>0.95\right)$ of the signal intensities across all slides shown in the tables below for both the Hy ${ }^{\mathrm{TM}}$ and $\mathrm{Hy} 5^{\mathrm{TM}}$ channels indicates that both labeling and hybridization were successful. 52 different spike-in controls were added in concentrations covering the full signal range. Each spike-in control has 4 replicates of capture probes on the array.

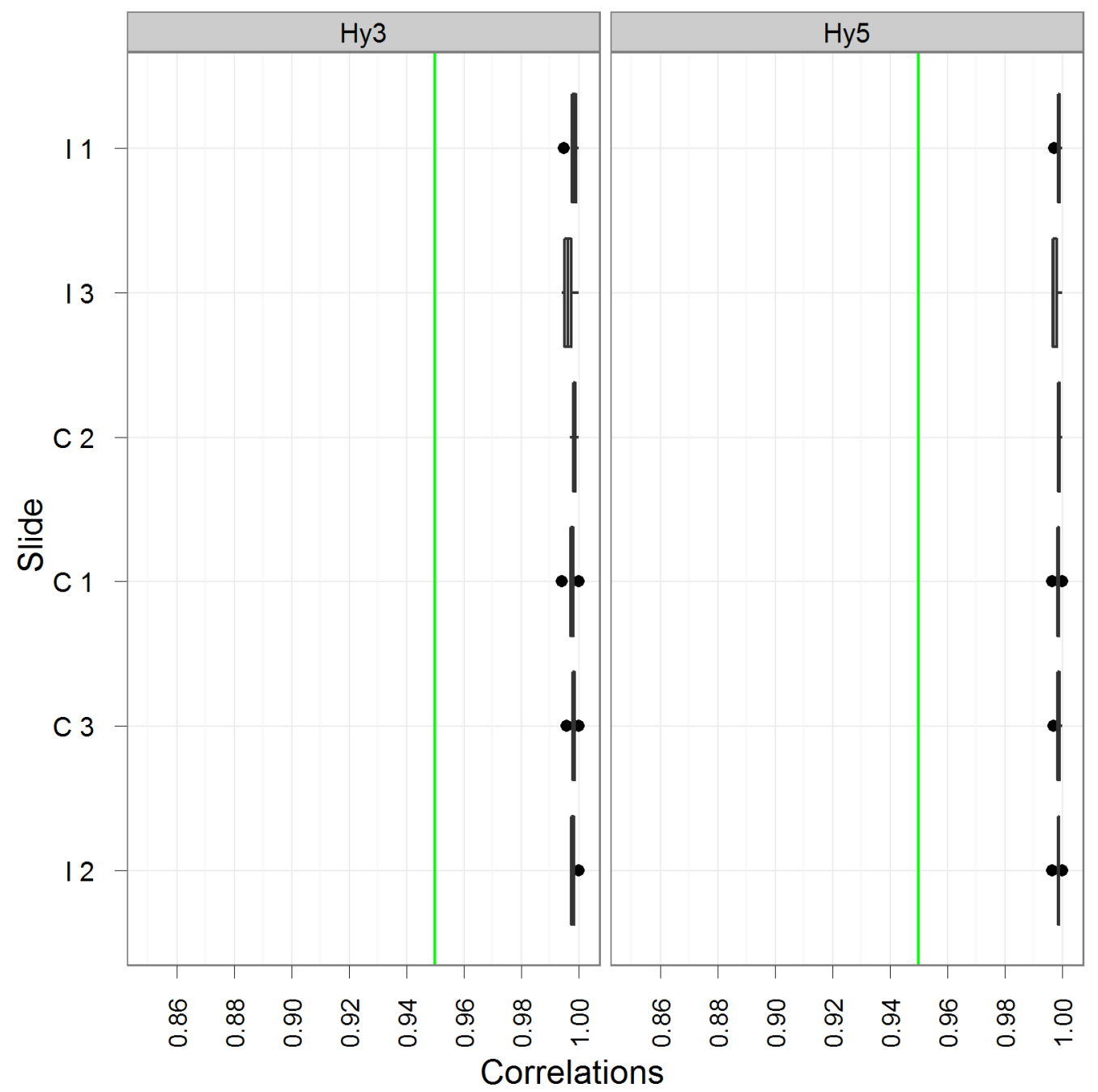

Figure 6: Box plot showing the correlation between spike-in controls on each slide to spike-in controls on the other slides in the study. A median (vertical black line) correlation higher than 0.95 (indicated by the green line) is considered as acceptable. Narrow boxes means that spike-in controls on the given slide correlate similarly to most other slides. Black dots refer to outlier correlations deviating significantly from the slides average correlation to other slide's spike-in controls. 


\section{EXIQON \\ Seek Find Verify}

\section{Effect of normalization}

Data normalization was performed to minimize differences between the colors in an intensitydependent manner. Normalization was performed using Lowess (Locally Weighted Scatterplot Smoothing) normalization. Lowess uses a locally established regression to smooth the M/A (log ratio/log mean-intensity) scatterplot toward a linear distribution. The Lowess algorithm works under the assumption that the majority of the signals between samples do not differ and it enforces equal overall means on all signal intensities. Therefore, Lowess allows the correction of systematic deviations in the MA plot resulting in an intensitydependent adjustment of MA-data to a straight line. We have found this normalization to produce the best within-slide normalization and thereby minimize the intensity-dependent differences between the dyes.

The positive effect of this normalization is illustrated in the MA-plots for each slide showing the plot before and after normalization. After normalization the spots appear symmetrically scattered around the horizontal line $M=0$. The difference between the two channels $(M)$ is now independent of the average intensity level of the two channels $(A)$. The array barcode is included in the graph legend. The MA plots are available in the folder named 'Maplots'.

Before normalization - 19720199

After normalization - 19720199
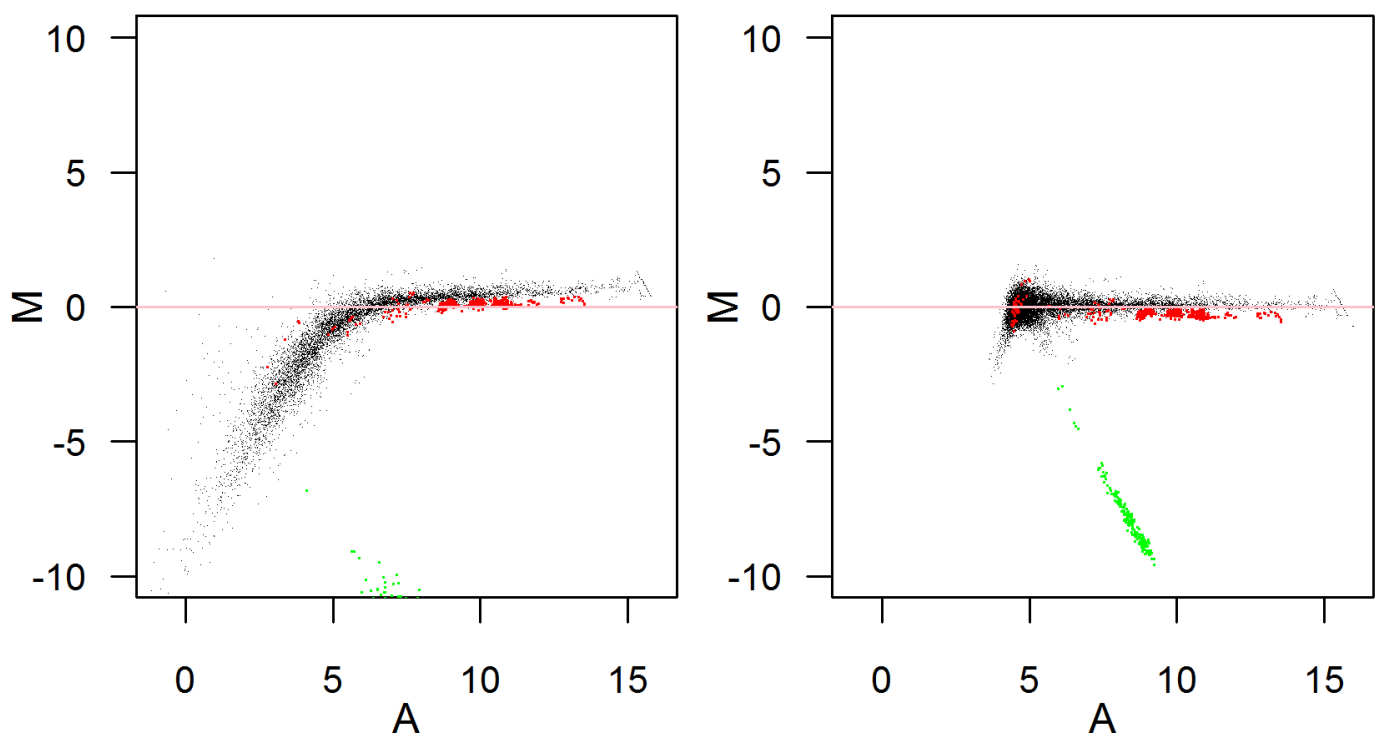

Figure 7: An example of an MA plot. All MA plots are found in the folder named MAplots. Green: Hy3 controls, red: spike-ins, black: all other probes. 


\section{EXIQON}

\section{Sample RNA quality control}

\section{Bioanalyzer}

Sample RNA Quality Control was performed using an Agilent 2100 bioanalyzer. The Bioanalyzer provides an electropherogram for each sample (see the RNA_QC.pdf - file) giving a good estimate of RNA integrity. As well as the traditional measurement of the rRNA ratio $(28 \mathrm{~S} / 18 \mathrm{~S}$ ), the Bioanalyzer provides a RIN value (RNA Integrity Number ranging from 0 to 10), which gives a reliable impression of the quality of the RNA (Schroeder et al, 2006). We normally recommend RIN values higher than 7 for good array performance.

The microRNA fraction is expected to lie in the range 25 to $30 \mathrm{sec}$ (see the RNA_QC.pdf file). Degradation of total RNA is observed as an increased number of peaks or as a smear in the range between 25 and $50 \mathrm{sec}$.

\section{Nanodrop}

The Nanodrop instrument was used for accurate measurement of concentrations (A260), protein contamination (ratio A260/A280) and contamination with buffer components, or organic compounds (ratio A260/A230). Compounds like phenol, Trizol ${ }^{\mathrm{TM}}$ and others aromatics may inhibit the labeling reaction giving inconclusive or negative results. For labeling and array hybridization, we normally recommend ratios above 1.8 for good array performance when Trizol $^{\mathrm{TM}}$ is used for purification. 


\title{
MicroRNA array profiling - material and methods
}

\author{
All experiments were conducted at Exiqon Services, Denmark. The quality of the total RNA \\ was verified by an Agilent 2100 Bioanalyzer profile. $750 \mathrm{ng}$ total RNA from both sample and \\ reference was labeled with $\mathrm{Hy} 3^{\mathrm{TM}}$ and $\mathrm{Hy} 5^{\mathrm{TM}}$ fluorescent label, respectively, using the \\ miRCURY LNA ${ }^{\mathrm{TM}}$ microRNA Hi-Power Labeling Kit, Hy3 $3^{\mathrm{TM}} / \mathrm{Hy} 5^{\mathrm{TM}}$ (Exiqon, Denmark) \\ following the procedure described by the manufacturer. The Hy $3^{\mathrm{TM}}$-labeled samples and a \\ $\mathrm{Hy} 5^{\mathrm{TM}}$-labeled reference RNA sample were mixed pair-wise and hybridized to the miRCURY \\ LNA ${ }^{\mathrm{TM}}$ microRNA Array 7th Gen (Exiqon, Denmark), which contains capture probes targeting \\ all microRNAs for human, mouse or rat registered in the miRBASE 18.0. The hybridization \\ was performed according to the miRCURY LNA ${ }^{\mathrm{TM}}$ microRNA Array Instruction manual using a \\ Tecan HS4800 ${ }^{\mathrm{TM}}$ hybridization station (Tecan, Austria). After hybridization the microarray \\ slides were scanned and stored in an ozone free environment (ozone level below $2.0 \mathrm{ppb}$ ) in \\ order to prevent potential bleaching of the fluorescent dyes. The miRCURY LNA ${ }^{\mathrm{TM}}$ microRNA \\ Array slides were scanned using the Agilent G2565BA Microarray Scanner System (Agilent \\ Technologies, Inc., USA) and the image analysis was carried out using the ImaGene $₫$ \\ (miRCURY LNA TM microRNA Array Analysis Software, Exiqon, Denmark). The quantified \\ signals were background corrected (Normexp with offset value 10, see Ritchie et al. 2007) \\ and normalized using the global Lowess (LOcally WEighted Scatterplot Smoothing) \\ regression algorithm.
}




\section{Frequently asked questions}

\section{Which controls were spiked-in?}

The miRCURY LNA ${ }^{\mathrm{TM}}$ microRNA Array contains a number of capture probes for hybridization to a range of synthetic RNA spike-in controls. Fifty-two (52) different spike-in controls were spiked into the labeling reaction.

\section{What is multiple testing correction?}

When a large number of statistical tests are carried out simultaneously, ordinary p-values need to be adjusted in order to control the number of false positives, i.e. the number of genes for which the null hypothesis 'the gene is equally expressed between groups' is incorrectly rejected - type I errors (Benjamini et al. 1995).

\section{What is moderated $t$-statistics?}

Moderated t-statistics has the same interpretation as an ordinary t-statistics. The difference is that the standard errors have been moderated across genes, i.e. shrunk towards a common value, using a simple Bayesian model. This has the effect of borrowing information from the ensemble of genes to aid with inference about each individual gene (Smyth et al, 2004).

\section{How is the M-value calculated?}

The M-value is calculated as the log median of the ratio for each of the four spots present on a slide. As the ratio is calculated for each spot individually prior to calculation of the median, the $M$-value cannot be calculated from the provided $G$ and $R$ values.

\section{How do I calculate the fold change?}

For each comparison the fold change is listed as log2transformed values in the logFC column. The fold change is calculated as $2^{\wedge} \log F C$.

\section{What is the coverage on 7thGen slides?}

The 7th generation of our array contains 3100 capture probes, covering all human, mouse and rat microRNAs annotated in miRBase 18.0, as well as all viral microRNAs related to these species. In addition, this array contains capture probes for 25 miRPlus $^{\text {TM }}$ human microRNAs. For coverage in the individual species, please see table below.

\begin{tabular}{lcccc} 
Organism name & $\begin{array}{c}\text { Organism } \\
\text { code }\end{array}$ & $\begin{array}{c}\text { Common } \\
\text { name }\end{array}$ & $\begin{array}{c}\text { In } \\
\text { miRBase 18 }\end{array}$ & $\begin{array}{c}\text { Array } \\
\text { 7th gen }\end{array}$ \\
\hline Homo sapiens & hsa & Human & 1921 & $99 \%$ \\
Mus musculus & $\mathrm{mmu}$ & Mouse & 1157 & $100 \%$ \\
Rattus norvegicus & rno & Rat & 680 & $100 \%$
\end{tabular}

Why are some microRNAs excluded from the unsupervised analysis (and which ones)? We offer full coverage of miRBase 18 on the $7^{\text {th }}$ generation slides, and all probes have been validated to hybridize specifically to the sequences in miRBase. We have however found that a small number of probes display atypical signal patterns (e.g. very high signal levels in many different sample types). We are therefore concerned that these signals may not represent biologically relevant microRNA expression. To avoid focusing on potentially false-positives, a total of 22 microRNAs were excluded from the unsupervised analysis. These microRNAs were however included in the supervised analysis. 


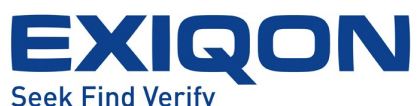

The excluded microRNAs are: hsa-miR-1246, hsa-miR-1273g-3p, hsa-miR-1280, hsa-miR1908, hsa-miR-3124-3p, hsa-miR-3686, hsa-miR-3940-5p, hsa-miR-3960, hsa-miR-4279, hsa-miR-4285, hsa-miR-4290, hsa-miR-4443, hsa-miR-4454, hsa-miR-4456, hsa-miR-4467, hsa-miR-4497, hsa-miR-4516, hsa-miR-4639-3p, hsa-miR-4708-3p, hsa-miR-4764-3p, hsamiR-4787-5p, hsa-miR-4800-3p, hsa-miR-5100.

\section{What is probe ID 13138 named $\mathrm{Hy}^{\mathrm{TM}}$ ?}

These are control spots with dye printed directly on the arrays for orientation of the grid in analysis. They only give signal in the Hy ${ }^{\mathrm{TM}}$ channel and were removed prior to normalization.

Where can I find the raw data from the scanning of my slides?

The raw data can be found in the txt-files for each slide, in the folder named Raw data files (X_Exiqon_barcode.txt).

\section{What are probes named miRPlus ${ }^{\mathrm{TM}}$ ?}

The miRPlus ${ }^{\mathrm{TM}}$ sequences are inlicensed human candidate microRNA sequences proprietary to Exiqon which are not yet annotated in miRBase. The miRPlus ${ }^{\mathrm{TM}}$ sequences constitute a mix of inlicensed microRNAs, Exiqon cloned sequences and microRNA sequences found in literature searches. The sequences have been subjected to strict quality control for validity. Typically, many of the miRPlus ${ }^{\mathrm{TM}}$ sequences will be submitted to future miRBase updates giving Exiqon customers unique early information about microRNAs not yet available elsewhere.

In order to access the miRPlus ${ }^{\mathrm{TM}}$ sequences, please contact Exiqon Technical Support, www.exigon.com/contact with the product number(s) and batch number(s) of your miRCURY LNA $^{\mathrm{TM}}$ microRNA Array. 


\section{Validating your array results with miRCURY LNA ${ }^{\mathrm{TM}}$ Universal RT microRNA PCR}

The following section is meant as a guideline for selecting the relevant microRNAs from your array study to be validated with qPCR. In order to be successful in this validation it is important to follow a set of criteria for selecting candidate microRNAs for validation. The important criteria to consider are the microRNA fold change in expression levels, statistical significance, array signal intensity, and reference microRNAs.

\section{Fold change}

It is recommended to identify microRNAs that show a sufficient level of regulation across the relevant groups of samples in the study. While it is possible to validate microRNAs that show small regulations it is important to remember that smaller fold changes tend to be relatively more affected by technical variance. Such changes are thus associated with increased risk of false-positive signals. Based on this we recommend to include microRNAs showing more than a 2-fold up- or down- regulation in a validation study by qPCR (corresponding to +/- 1.0 logFoldChange). To study microRNAs with small fold regulations, considerably more technical or biological replicates should be included in the validation.

\section{Statistical significance}

For studies where at least three replicates have been supplied for each group, the array report includes $p$-values. These should be used to evaluate the significance of the findings. In the sheets named ExpAnalysis(\#).xlsx, the $p$-values and possibly adjusted $p$-values are listed for the performed comparisons. For the adjusted $p$-values, values $<0.05$ should be considered as significant, and microRNAs showing a statistically significant regulation have a greater chance of validating by qPCR.

\section{Array signal intensity}

When selecting candidates for validation, it is important to ensure that the signal intensity of the probes is well above the background. If microRNA capture probe signals are close to the background, this indicates that the microRNAs are present at a concentration that is close to or below the detection level of the array. For these probes, calculation of ratios and fold change become very uncertain, possibly resulting in very high fold changes or ratios. Such expression changes are associated with an increased risk of false positive signals. To ensure that the expression changes are calculated based on signal intensities well above the array background, the average signal intensity should be inspected in the ExpAnalysis(\#).xlsx file (or Norm.xlsx if no group-wise comparison has been performed). We recommend signal intensities in the range 7.5-14.5 for experiments conducted at Exiqon Services.

\section{Selecting reference genes for qPCR normalization}

In general, we recommend that the endogenous reference genes used should be stably expressed microRNAs rather than longer RNA species such as snoRNAs and snRNAs including U6. This is because microRNAs are so short that they may have very different behavior during extraction and reverse transcription compared to longer transcripts (Vandesompele et al., 2002). The array experiment may be able to provide you with information on which microRNAs that could serve well as reference genes for normalization in qPCR. The general idea is to identify microRNAs which show a very stable (constant) expression across the different samples in the study. To identify such stably expressed genes, estimate expression stability using e.g. NormFinder (www.mdl.dk) or geNorm (Vandesompele et al., 2002). For Dual color experiments, calculate stability based on the $M$ value (ratio), for single-color experiments use normalized G values (found in Norm.xlsx file). When choosing 
reference genes, the above-mentioned criteria for signal intensity should also be met (recommended signal intensities in the range $7.5-14.5$ for average Hy3 values).

Quick guide for validation

Use the document ExpAnalysis(\#).xlsx to select your candidates for validation.

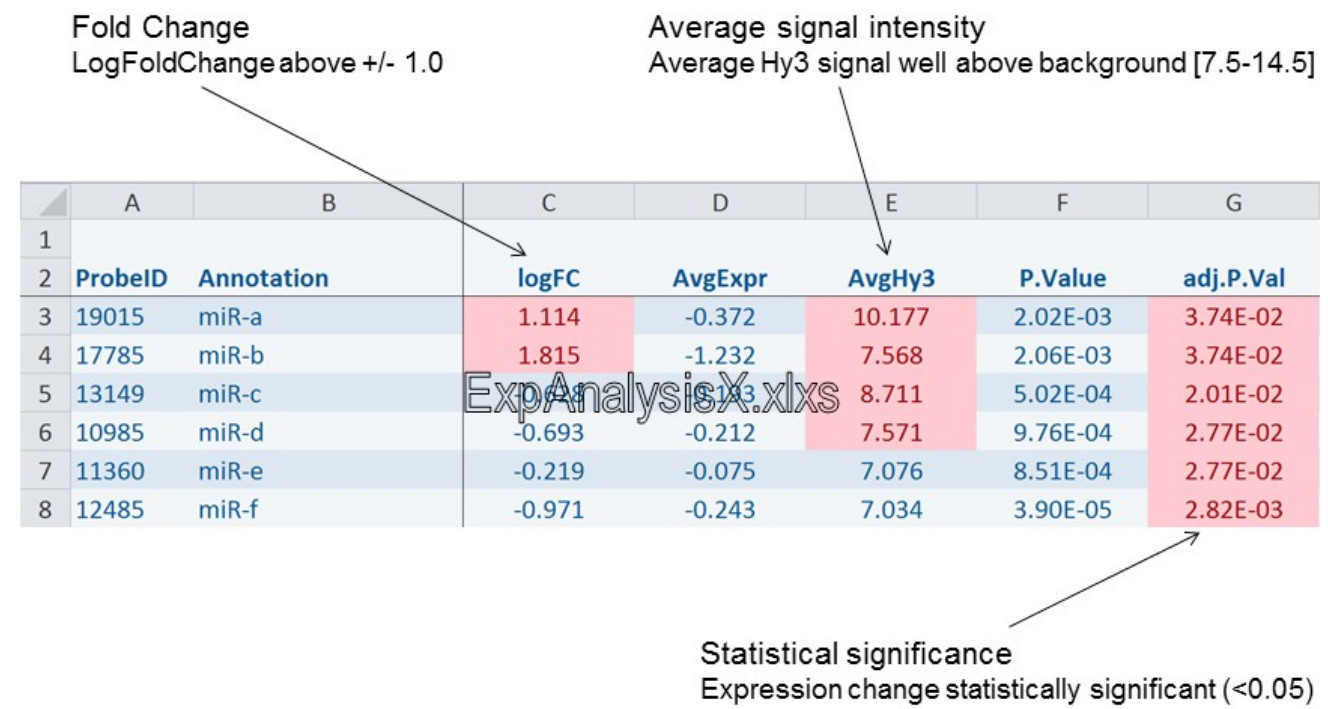

\section{What to avoid when validating array experiments}

microRNAs related to degradation of samples. Poor correlation between array and qPCR results may arise if the RNA samples are degraded. Most microRNAs will be detected well and unaffected by degradation by both GPCR and array. However, in some situations even the microRNAs are partially degraded with 1-2 end nucleotides. Typically, array capture probes may still detect such partially degraded microRNAs whereas the miRCURY TM LNA Universal RT microRNA qPCR primers will discriminate microRNAs that are one or more nucleotides shorter. In these cases qPCR and array results may not correlate well. Furthermore, for degraded RNA samples, fragments of larger RNA species that contain microRNA-like sequences may start to hybridize to the capture probes. There are several microRNAs that have great sequence similarity to e.g. tRNAs (miR-1280, miR-1275, miR-720). However, the nature of the qPCR assay design will not detect such microRNA-like sequences present on either intact or degraded fragments of larger RNA species. Consequently, qPCR and array results will not correlate well for such microRNAs. To check whether your candidate microRNA could be affected by this, please consult the literature and check if there is sequence similarity to larger RNA species.

microRNAs related to sampling. For some experimental setups there is a risk of introducing differences that are solely related to sampling of RNA. A typical example of this is the presence of blood derived microRNAs in some samples, but not in other samples, as these samples were perfused more thoroughly with saline prior to fixation. This may be detected as differential expression, but will not necessarily be reproducible in a new sample set. The microRNAs that are typical signs of blood contamination are miR-451, and miR-144. 


\section{Legends for normalized data files}

Various data files are provided with the report. See description below.

norm.xlsx file - includes normalized data (normalized using relevant method). Data is separated in three or more sheets as outlined below:

- G: log2transformed normalized median intensity values (Hy3)

- M: log2transformed median ratios. This sheet is only included for Lowess normalized data. $M$ is calculated as the log median of the ratios calculated pr. spot.

- R: log2transformed normalized median intensity values (Hy5) In each sheet the data is organized as outlined below:

- Column A: ProbelD. Unique ProbelD identifying the detection probe used.

- Column B: Annotation. Annotated microRNA detected by the given probe.

- Columns C - xx: Columns with data.

ThresholdFilteredData.xIsx - includes the log2transformed normalized median ratios (M) from the full dataset (as seen in norm.xlsx) that are detected above background. For Quantile normalization the file includes normalized intensity values (Hy3). See applied background setting in ProjectSummaryReport. Data that are below the set threshold are annotated "\#NUM!".

ExpAnalysis\#.xlsx file - includes data from M.csv (or G.csv for single color experiments) and the corresponding analysis data / statistics. The top row specified the grouping of the samples (column $\mathrm{H}$ and onwards)

- ProbelD. Unique ProbelD identifying the detection probe used.

- Annotation. Annotated microRNA detected by the given probe.

- LogFC. Log2(FoldChange) value when comparing two sample groups of interest. This corresponds to deltaLogMedianRatios or deltaLogMedianSignals.

- AveExpr. The average expression level (M or $\mathrm{G})$ calculated based on all samples included in the comparison.

- AvgHy3. Log2 (average Hy3 signal intensity).

- P.Value. $p$-value calculated from t-statistics comparing the two sample groups.

- adj.P.Val. Adjusted p-value from t-statistics comparing the two sample groups.

- Column $\mathrm{H}$ and onwards. Data for the individual samples included in the performed analysis 


\section{References}

Smyth et al. Statistical Applications in Genetics and Molecular Biology 2004.3: Article 3

Schroeder et. al. BMC Mol Biol. 2006 Jan 31;7:3.

Ritchie et al. Bioinformatics 2007, Vol. 23 no. 20 2007, pages 2700-2707

Benjamini and Hochberg 1995.Journal of the Royal Statistical Society Series B, ${ }^{*} 57^{*}, 289-300$.

Vandesompele et al., Genome Biology, 2002 


\section{Questions to products and orders}

Outside North America

\section{Business hours}

8:30 a.m. - 4:30 p.m.

Central European Time (GMT +100)

Mailing address

Exiqon A/S

Skelstedet 16

2950 Vedbaek

Denmark

Phone: +45 45650929

Fax: +45 45650459

Email (form): exiqon.com/contact

\author{
North America
}

Business hours

8:30 a.m. - 4:30 p.m.

Eastern Standard Time

\section{Mailing address}

Exiqon, Inc.

12 Gill Street

Woburn, MA 01801

United States

Phone: +1 7813764150

Fax: +1 7813764152

Toll free (US \& Canada):

+1888 miRCURY

Email (form): exiqon.com/contact 